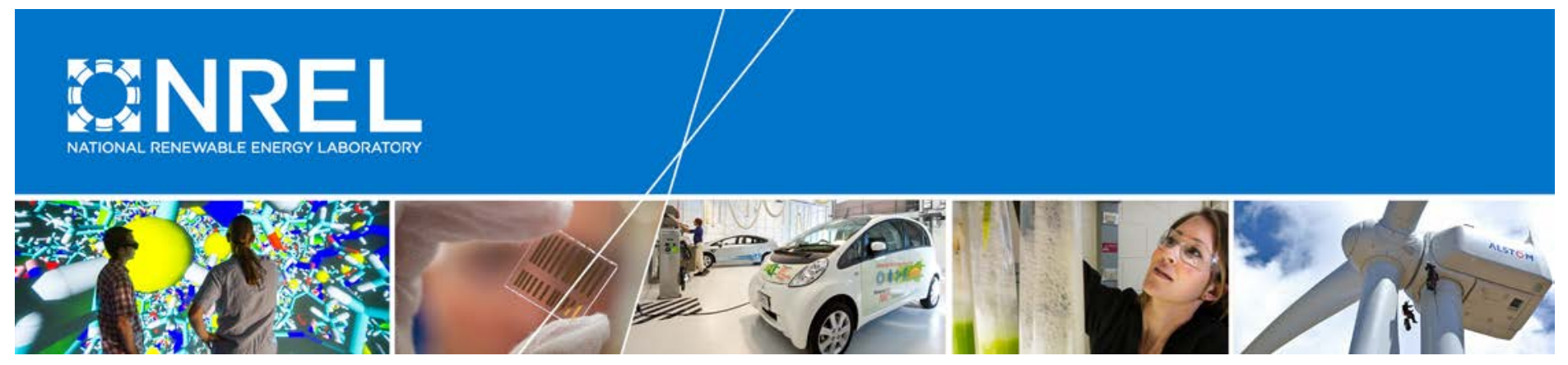

\title{
Foothill Transit Battery Electric Bus Demonstration Results: Second Report
}

Leslie Eudy and Matthew Jeffers National Renewable Energy Laboratory

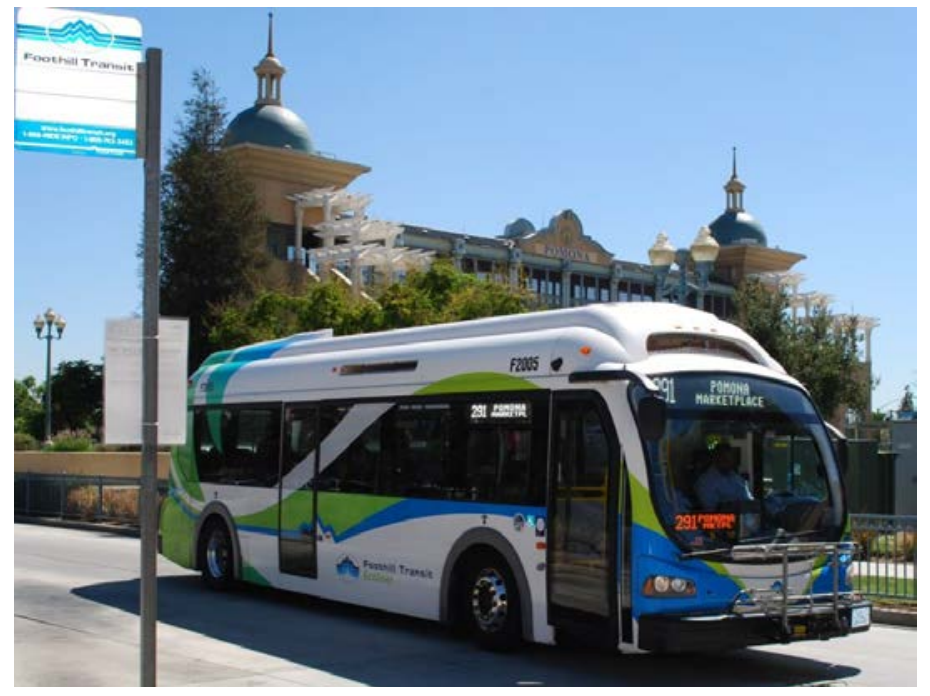

NREL is a national laboratory of the U.S. Department of Energy Office of Energy Efficiency \& Renewable Energy Operated by the Alliance for Sustainable Energy, LLC

This report is available at no cost from the National Renewable Energy Laboratory (NREL) at www.nrel.gov/publications.

Technical Report

NREL/TP-5400-67698

June 2017

Contract No. DE-AC36-08GO28308 


\title{
Foothill Transit Battery Electric Bus Demonstration Results: Second Report
}

\author{
Leslie Eudy and Matthew Jeffers \\ National Renewable Energy Laboratory
}

Prepared under Task No. WW4K.1000

NREL is a national laboratory of the U.S. Department of Energy Office of Energy Efficiency \& Renewable Energy Operated by the Alliance for Sustainable Energy, LLC

This report is available at no cost from the National Renewable Energy Laboratory (NREL) at www.nrel.gov/publications.

National Renewable Energy Laboratory 15013 Denver West Parkway Golden, CO 80401

303-275-3000 • www.nrel.gov

\section{Technical Report}

NREL/TP-5400-67698

June 2017

Contract No. DE-AC36-08GO28308 


\section{NOTICE}

This report was prepared as an account of work sponsored by an agency of the United States government. Neither the United States government nor any agency thereof, nor any of their employees, makes any warranty, express or implied, or assumes any legal liability or responsibility for the accuracy, completeness, or usefulness of any information, apparatus, product, or process disclosed, or represents that its use would not infringe privately owned rights. Reference herein to any specific commercial product, process, or service by trade name, trademark, manufacturer, or otherwise does not necessarily constitute or imply its endorsement, recommendation, or favoring by the United States government or any agency thereof. The views and opinions of authors expressed herein do not necessarily state or reflect those of the United States government or any agency thereof.

This report is available at no cost from the National Renewable Energy Laboratory (NREL) at www.nrel.gov/publications.

Available electronically at SciTech Connect http:/www.osti.gov/scitech

Available for a processing fee to U.S. Department of Energy and its contractors, in paper, from:

U.S. Department of Energy

Office of Scientific and Technical Information

P.O. Box 62

Oak Ridge, TN 37831-0062

OSTI http://www.osti.gov

Phone: 865.576.8401

Fax: 865.576.5728

Email: reports@osti.gov

Available for sale to the public, in paper, from:

U.S. Department of Commerce

National Technical Information Service

5301 Shawnee Road

Alexandria, VA 22312

NTIS http://www.ntis.gov

Phone: 800.553 .6847 or 703.605 .6000

Fax: 703.605.6900

Email: orders@ntis.gov 


\section{Acknowledgments}

This evaluation at Foothill Transit would not have been possible without the support and cooperation of many people. The authors thank the following individuals:

\section{California Air Resources Board}

Yachun Chow

Jennifer Lee

U.S. Department of Energy's National Renewable Energy Laboratory

Keith Wipke

Jen Kurtz

Matthew Post

Foothill Transit

Doran Barnes

Roland Cordero

Andrew Papson

Luis Renderos

Proterra

Mike Finnern

Derrick Allen

Unless otherwise noted, all photos by L. Eudy, NREL 


\section{Acronyms and Abbreviations}

$\begin{array}{ll}\text { BEB } & \text { battery electric bus } \\ \text { CARB } & \text { California Air Resources Board } \\ \text { CNG } & \text { compressed natural gas } \\ \text { dge } & \text { diesel gallon equivalent } \\ \text { DOE } & \text { U.S. Department of Energy } \\ \text { ESS } & \text { energy storage system } \\ \text { FCEB } & \text { fuel cell electric bus } \\ \text { ft } & \text { feet } \\ \text { FTA } & \text { Federal Transit Administration } \\ \text { gge } & \text { gasoline gallon equivalent } \\ \text { GVWR } & \text { gross vehicle weight rating } \\ \text { hp } & \text { horsepower } \\ \text { HVAC } & \text { heating, ventilation, and air conditioning } \\ \text { in. } & \text { inches } \\ \text { kg } & \text { kilograms } \\ \text { kW } & \text { kilowatts } \\ \text { kWh } & \text { kilowatt hours } \\ \text { lb } & \text { pounds } \\ \text { LCFS } & \text { Low Carbon Fuel Standard } \\ \text { MBRC } & \text { miles between roadcalls } \\ \text { mph } & \text { miles per hour } \\ \text { NREL } & \text { National Renewable Energy Laboratory } \\ \text { PMI } & \text { preventive maintenance inspection } \\ \text { psi } & \text { pounds per square inch } \\ \text { PTC } & \text { Pomona Transit Center } \\ \text { SI } & \text { International System of Units } \\ \text { TIGGER } & \text { Transit Investments for Greenhouse Gas and Energy } \\ \text { TRL } & \text { Reduction } \\ \text { ZBus } & \text { technology readiness level } \\ & \text { zero-emission bus } \\ & \end{array}$




\section{Definition of Terms}

Availability: The number of days the buses are actually available compared to the days that the buses are planned for operation, expressed as percent availability.

Average driving speed: The average speed of the buses while driving, not including stops and idle time. These data are collected using data loggers.

Clean point: For each evaluation, NREL works with the project partners to determine a starting point — or clean point - for the data analysis period. The clean point is chosen to avoid some of the early and expected operations problems with a new vehicle going into service, such as early maintenance campaigns. In some cases, reaching the clean point may require 3 to 6 months of operation before the evaluation can start.

Deadhead: The miles and hours that a vehicle travels when out of revenue service with no expectation of carrying revenue passengers. Deadhead includes leaving or returning to the garage or yard facility and changing routes.

Miles between roadcalls (MBRC): A measure of reliability calculated by dividing the number of miles traveled by the number of roadcalls. (Also known as mean distance between failures.) MBRC results in the report are categorized as follows:

- Bus MBRC: Includes all chargeable roadcalls. Includes propulsion-related issues as well as problems with bus-related systems such as brakes, suspension, steering, windows, doors, and tires.

- Propulsion-related MBRC: Includes roadcalls that are attributed to the propulsion system. Propulsion-related roadcalls can be caused by issues with the transmission, batteries, and electric drive.

- Energy storage system (ESS)-related MBRC: Includes roadcalls attributed to the energy storage system only.

Revenue service: The time when a vehicle is available to the general public with an expectation of carrying fare-paying passengers. Vehicles operated in a fare-free service are also considered revenue service.

Roadcall: A failure of an in-service bus that causes the bus to be replaced on route or causes a significant delay in schedule. The analysis includes chargeable roadcalls that affect the operation of the bus or may cause a safety hazard. Non-chargeable roadcalls can be passenger incidents that require the bus to be cleaned before going back into service, or problems with an accessory such as a farebox or radio. 


\section{Executive Summary}

This report summarizes results of a battery electric bus (BEB) evaluation at Foothill Transit, located in the San Gabriel and Pomona Valley region of Los Angeles County, California. Foothill Transit began a demonstration of three Proterra BEBs in October 2010 to evaluate the battery technology and determine if the BEBs could meet Foothill Transit's service requirements. The initial demonstration went well and in 2014, Foothill Transit moved forward with an order of twelve next-generation BEBs from Proterra through a $\$ 10.2$ million grant under the Federal Transit Administration's (FTA's) Transit Investments for Greenhouse Gas and Energy Reduction (TIGGER) Program. Foothill Transit's project goal was to fully electrify one route in its service area-Line 291 - and to investigate the feasibility of the technology for other routes. These electric buses are $35-\mathrm{ft}$ composite-body buses that are capable of being charged quickly on route via Proterra's overhead charging system. The buses are charged midway along the route at a charging station built at the Pomona Transit Center. Foothill Transit began operating the new fleet of electric buses on line 291 in March 2014.

Foothill Transit is collaborating with the California Air Resources Board (CARB) and the U.S. Department of Energy's (DOE's) National Renewable Energy Laboratory (NREL) to evaluate the buses in revenue service. CARB has been gathering data on zero-emission buses (ZBuses) to assess the status of the technology. The majority of ZBus data collected and reported to date are for fuel cell electric buses. CARB would like to have similar analysis and reporting for the other primary ZBus technology being adopted in the state of California, that is, BEBs. NREL has been evaluating advanced technology buses under funding from DOE and the U.S. Department of Transportation's FTA. The objectives of these evaluations are to provide comprehensive, unbiased evaluation results of advanced technology bus development and performance compared to conventional vehicles. CARB has enlisted NREL to conduct a third-party evaluation of Foothill Transit's electric bus fleet.

The focus of this evaluation is to compare the performance and the operating costs of the BEBs to that of the baseline conventional technology buses and to track progress over time. In the commercialization process described by technology readiness levels (TRLs) 1 through 9-from basic research/concept to commercial deployment-NREL considers the BEBs to be at TRL 7 . The primary goals of the in-service demonstration are to verify that technical performance targets are met and to identify any issues that need to be resolved. More information regarding TRLs as they relate to advanced technology bus commercialization is provided in Appendix A.

Conventional technology buses that best match the advanced technology buses in terms of size, weight, model year, and intended operation are selected as baseline buses for the evaluation to provide the best possible comparison of performance and cost. The baseline buses selected at Foothill Transit are eight 42-foot NABI compressed natural gas (CNG) buses of the same model year as the Proterra BEBs.

This is the second report summarizing the results of the BEB demonstration at Foothill Transit. The first report covered the initial data period of April 2014 through July 2015. This report provides data and analysis on the twelve Proterra BEBs and eight NABI CNG baseline buses from August 2015 through December 2016. Table ES-1 provides a summary of results for several categories of data presented in this report. The data from the previous report are included 
for reference. The BEBs have traveled more than 902,000 miles since the start of the demonstration through December 2016. This equates to an average of more than 75,000 miles per BEB during this evaluation.

Table ES-1. Summary of Evaluation Results

\begin{tabular}{|c|c|c|c|c|}
\hline Data Item & $B E B$ & $\mathrm{BEB}$ & CNG & CNG \\
\hline Number of buses & 12 & 12 & 8 & 8 \\
\hline Data period & $4 / 14-7 / 15$ & $8 / 15-12 / 16$ & $10 / 14-7 / 15$ & $8 / 15-12 / 16$ \\
\hline Number of months & 16 & 17 & 10 & 17 \\
\hline Total mileage in data period & 401,244 & 501,037 & 364,373 & 656,399 \\
\hline Average odometer & 33,437 & 77,705 & 45,547 & 132,405 \\
\hline Average monthly mileage per bus & 2,333 & 2,456 & 4,555 & 4,826 \\
\hline Total operating hours & 47,462 & 58,497 & - & - \\
\hline Availability ( $85 \%$ is target) & 90 & 90 & 94 & 93 \\
\hline Fuel economy (kWh/mile or miles/gge $\left.{ }^{a}\right)$ & 2.15 & 2.17 & 4.04 & 3.89 \\
\hline Fuel economy (miles/dge ${ }^{\mathrm{b}}$ ) & 17.48 & 17.35 & 4.51 & 4.34 \\
\hline Average speed, including stops (mph) & 10.6 & 8.57 & 17.6 & 17.6 \\
\hline Miles between roadcalls (MBRC) - bus $^{c}$ & 9,331 & 6,180 & 45,547 & 29,165 \\
\hline MBRC - propulsion system only ${ }^{c}$ & 25,078 & 16,405 & 91,093 & 56,710 \\
\hline MBRC - ESS $^{\mathrm{d}}$ only ${ }^{\mathrm{c}}$ & 133,748 & 300,760 & - & - \\
\hline Total maintenance $(\$ / \text { mile })^{\mathrm{e}}$ & $\$ 0.16$ & $\$ 0.21$ & $\$ 0.18$ & $\$ 0.22$ \\
\hline Total maintenance (\$/mile without tire costs) & $\$ 0.12$ & $\$ 0.14$ & $\$ 0.18$ & $\$ 0.20$ \\
\hline $\begin{array}{l}\text { Maintenance - propulsion system only } \\
\text { (\$/mile) }\end{array}$ & $\$ 0.02$ & $\$ 0.02$ & $\$ 0.08$ & $\$ 0.07$ \\
\hline
\end{tabular}

${ }^{\mathrm{a}}$ Gasoline gallon equivalent.

${ }^{\mathrm{b}}$ Diesel gallon equivalent.

${ }^{\mathrm{c}}$ MBRC data cumulative from the clean point of April 2014 through December 2016.

${ }^{\mathrm{d}}$ Energy storage system.

${ }^{\mathrm{e}}$ Work order maintenance cost.

For the most recent data period, the average monthly operating mileage per bus for the BEBs was 2,456 miles, which was about half that of the CNG buses (4,826 miles). This large difference in accumulated mileage is expected due to the planned operation of the buses and should not be interpreted as a limitation of the battery technology. The BEBs are operated primarily on Line 291 and the CNG buses are randomly dispatched on all routes out of the Pomona Operations and Maintenance facility, including express and commuter routes that have much higher average speeds. This higher average speed has an impact on the fuel efficiency of the CNG buses and should be taken into consideration when making comparisons.

The average availability for the BEBs during the data period was $90 \%$ compared to $93 \%$ for the CNG baseline buses. This is consistent with the previous data period (90\% and $94 \%$, respectively). The per-bus availability for the BEBs ranged from a low of $84 \%$ to a high of $96 \%$. Most of the issues causing downtime were general bus maintenance issues not related to the propulsion system. General bus system issues caused the majority of downtime for the BEBs, followed by electric drive system issues. For the CNG buses, the majority of downtime was caused by general bus system issues, followed by engine issues.

The BEBs had an overall average efficiency of $2.17 \mathrm{kWh}$ per mile, which equates to 17.35 miles per diesel gallon equivalent (mpdge). The CNG buses had an average fuel economy of 3.89 
miles per gasoline gallon equivalent (mpgge), which equates to 4.34 mpdge. The operating duty cycle of a bus has a significant effect on fuel economy. Because Foothill Transit operates its $\mathrm{BEB}$ and CNG bus fleets differently, the efficiency results presented here are not considered an apples-to-apples comparison. In collaboration with a DOE-funded activity at NREL, the researchers had access to data collected on a selection of Foothill Transit CNG buses using data loggers. The data loggers recorded two days of CNG operation on Line 291 to provide a direct comparison to the BEBs in this evaluation. On Line 291, the average CNG fuel economy was 2.1 mpdge and the average driving speed (not including stops and idle time) was $18.1 \mathrm{mph}$. This is similar to the average driving speed (logged) for the BEBs $(17.8 \mathrm{mph})$, providing a more accurate comparison for fuel economy. When comparing the logged data, the BEB fuel economy is more than 8 times higher than that of a CNG bus operating exclusively on Line 291.

During the data period, Foothill Transit paid an average of $\$ 0.17 / \mathrm{kWh}$ for electricity for the BEBs and \$0.96/gge for CNG. Based on actual energy used by the buses, the energy cost for the BEB fleet calculates to $\$ 0.37$ per mile. When taking into account the total electricity Foothill Transit purchased from the utility to charge the buses, the energy cost is $\$ 0.41$ per mile. This difference of $\$ 0.04$ per mile reflects the expected energy loss of approximately $10 \%$ during charging. The average per-mile energy cost for the CNG buses operated at a higher average speed was $\$ 0.25$ per mile. To compare cost between buses in the same service, NREL estimated the cost per mile for the CNG buses if operated only on Line 291. The lower fuel economy would increase the cost of the CNG buses to an overall average of $\$ 0.50$ per mile, which is higher than the cost of the BEB fleet. This does not reflect the credits from the Low Carbon Fuel Standard program, which results in a greater benefit for using electricity over CNG. CNG buses generate Low Carbon Fuel Standard credits, although not as many as electric vehicles do.

Time of use and demand charges factor into the cost of electricity for Foothill Transit. When the first three BEBs were deployed, Proterra and Foothill Transit were concerned that the maximum demand would exceed $500 \mathrm{~kW}$, moving the agency into an industrial rate schedule, which has high demand charges. This would result in much higher costs for the agency. To help address this issue, the California Public Utilities Commission issued resolution E-4514, which allowed Foothill Transit to stay on the small commercial schedule that has no demand charges. That exemption expired at the end of 2015. Southern California Edison has established additional rate schedules specifically for customers using electric vehicles. TOU-EV-4 is applicable to customers whose monthly demand is between $20 \mathrm{~kW}$ and $500 \mathrm{~kW}$. Foothill Transit worked with Proterra to implement charge management software that controls the charging demand to stay under the $500 \mathrm{~kW}$ threshold. The combination of rate schedule and charge management resulted in a lower electricity cost for the agency in the most recent data period.

NREL continued to track the bus reliability — measured as miles between roadcalls (MBRC) during the second data period. The overall bus MBRC for the BEB fleet decreased from more than 9,000 to just over 6,000. This is higher than the target of 4,000 MBRC but much lower than that of the CNG buses, which achieved more than 29,000 MBRC. The propulsion system-related MBRC was 16,405 for the BEBs compared to 56,710 for the CNG buses. There have been only three roadcalls for the energy storage system (ESS) during the evaluation (none in the latest data period). Thus, the ESS-related MBRC for the BEBs continues to climb, now surpassing 300,000. 
NREL also analyzed work order data to provide a comparison of maintenance costs between the $\mathrm{BEBs}$ and the baseline CNG fleet. After removing accident- and warranty-related items for both fleets, the average per-mile maintenance cost for the data period was $\$ 0.21 / \mathrm{mi}$ for the BEBs and $\$ 0.22 / \mathrm{mi}$ for the CNG buses. These combined totals include scheduled and unscheduled maintenance. Although the totals are very similar, the BEBs have lower scheduled maintenance costs $(\$ 0.07 / \mathrm{mi})$ than the CNG buses $(\$ 0.11 / \mathrm{mi})$. During this period, the BEBs experienced higher unscheduled maintenance costs $(\$ 0.14 / \mathrm{mi})$ than the $\mathrm{CNG}$ buses $(\$ 0.10 / \mathrm{mi})$. The cost for tire damage, which is not related to the technology, accounted for $\$ 0.07 / \mathrm{mi}$ to the overall cost of the BEBs. Foothill Transit reports that this is likely due to the differing use between the BEBs and $\mathrm{CNG}$ buses. The local routes tend to have more road damage, such as potholes and broken curbs. Since the BEBs are operated mainly on local routes, they incur more tire-related damage compared with the $\mathrm{CNG}$ buses that are often driven on freeways. The agency expects that the CNG buses would experience similar tire damage as the BEBs if they were only operated on the local routes. Average scheduled and unscheduled maintenance costs for the $\mathrm{CNG}$ buses were strongly impacted by a major preventive maintenance inspection (PMI) reached by many of the buses in the middle of the data period. When excluding tire damage, the total maintenance cost is $\$ 0.14 / \mathrm{mi}$ for BEBs and $\$ 0.20 / \mathrm{mi}$ for CNG buses. The BEBs had a propulsion-system-only maintenance cost that was $70 \%$ lower than that of the CNG buses: $\$ 0.02 / \mathrm{mi}$ for the BEBs compared to $\$ 0.07 / \mathrm{mi}$ for the $\mathrm{CNG}$ buses.

The top three vehicle systems that accounted for the largest fraction of maintenance for the BEBs were (in order from highest to lowest) tires (34\%); PMI (33\%); and cab, body and accessories $(17 \%)$. For the CNG buses, the top three vehicle systems for maintenance were propulsionrelated (32\%); PMI (24\%); and cab, body and accessories (21\%).

There have been many achievements for the demonstration, including the following:

- The current fleet of twelve 35-ft BEBs continues to operate well, accumulating more than 902,000 miles (through December 2016). Foothill Transit's combined fleet of 17 Proterra BEBs (including three first-generation BEBs and two new 40-ft BEBs) has operated more than $1,134,000$ miles.

- Bus MBRC for the entire evaluation period is more than 6,000 , surpassing the target of 4,000 MBRC. Propulsion-related MBRC is more than 16,000.

- The on-route fast chargers operated reliably with minimal issues, none of which resulted in downtime for the buses. Foothill Transit's combined BEB fleet (17 buses) has been charged more than 119,000 times since the fast chargers were installed. Availability of the two charging heads was $98 \%$ and $99 \%$.

- Proterra reports that the high voltage batteries are showing little to no signs of capacity degradation to date, and current estimates show they may last for up to 12 years.

Foothill Transit and Proterra report that the project continues to go well. The partners highlight the following key lessons learned since the beginning of the project:

- Short-range, on-route-charged buses are inflexible and cannot be deployed at other service routes that do not connect to an on-route charging location. 
- Review potential routes and consider the ones that best fit how BEBs operate based on driving range, duty cycle, and charging opportunities. An agency could benefit from conducting a route analysis and simulating how the BEBs would meet the range requirements.

- Adjust route schedules to accommodate BEB charging time; this is part of the transition from conventional technology buses to electric buses. An agency may need to add deadhead miles prior to the start of the route depending on the location of the in-route charging station and availability of an in-depot charger.

- The higher use of air conditioning lowers the effective range in hotter months; Foothill Transit adjusts its summer schedule to account for more charging time.

- Charger availability is important for successful deployment. Foothill Transit installed two charger heads at its charging station to avoid downtime for charger unavailability.

Foothill Transit reports that there is still a lot of learning as the agency ramps up to a larger BEB fleet. The agency has a goal of transitioning its fleet to $100 \%$ electric by 2030 . The team needs to consider the operational differences for BEBs and develop plans in achieving this goal. 


\section{Table of Contents}

Introduction 1

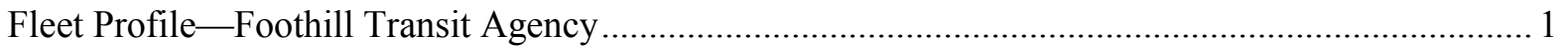

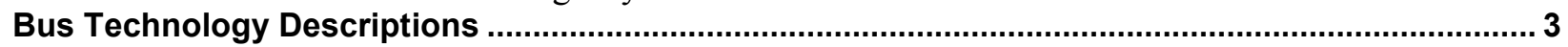

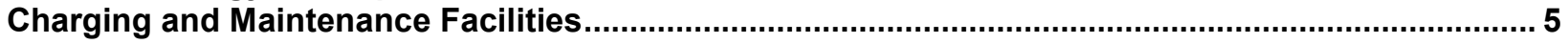

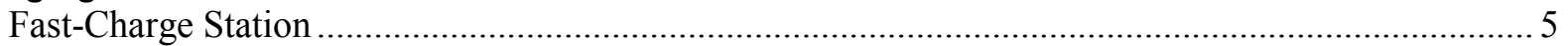

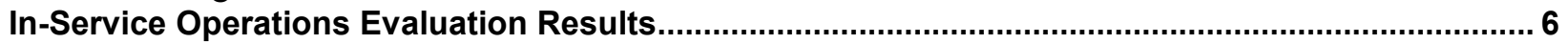

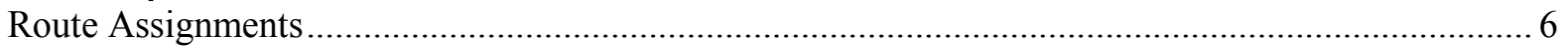

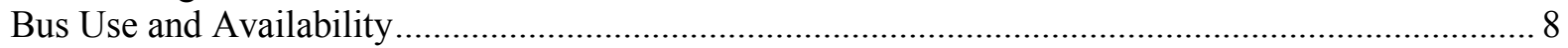

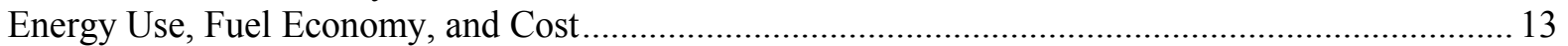

Challenge of Comparing Technologies with Different Duty Cycles ........................................ 15

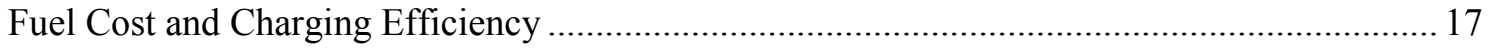

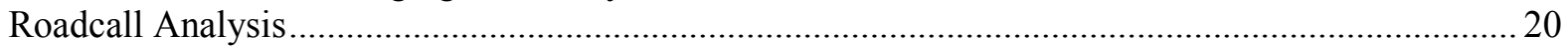

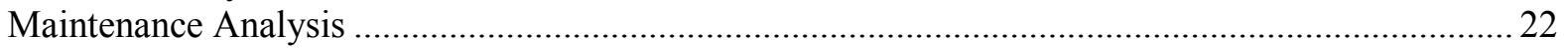

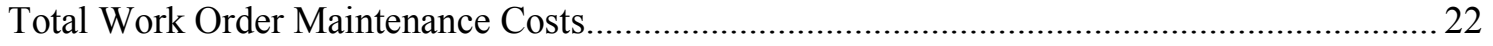

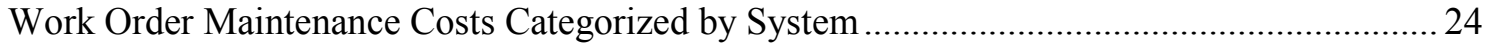

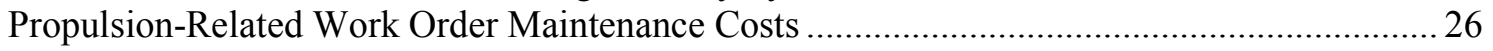

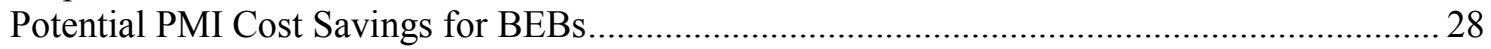

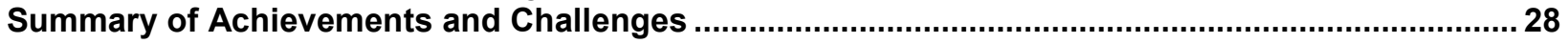

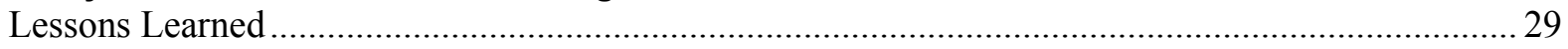

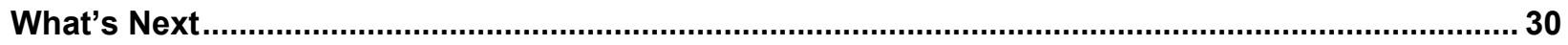

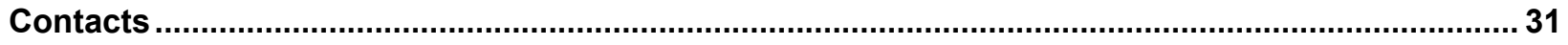

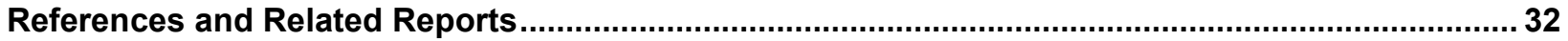

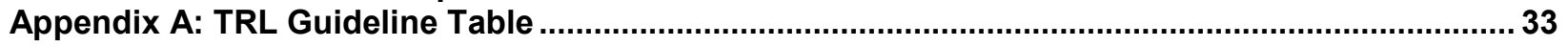

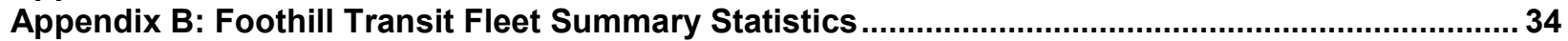

Appendix C: Foothill Transit Fleet Summary Statistics_SI Units .............................................. 41

Appendix D: Charts for Entire In-Service Period (All Data) ................................................................ 43 


\section{Introduction}

Beginning in March 2014, Foothill Transit has been operating a fleet of 12 battery electric buses (BEBs) in its service area located in the San Gabriel and Pomona Valley region of Los Angeles County, California. These electric buses, produced by Proterra, are 35-foot, composite body buses that are capable of being charged quickly on route. Foothill Transit is collaborating with the California Air Resources Board (CARB) and the U.S. Department of Energy's (DOE's) National Renewable Energy Laboratory (NREL) to evaluate the buses in revenue service. CARB, primarily through evaluations conducted by NREL, has been monitoring the development progress of zero-emission buses (ZBuses) being demonstrated in California and other parts of the United States. Most of the early NREL evaluations were focused on fuel cell electric buses (FCEBs). The introduction of opportunity fast charging addressed the early range issues that were a challenge for deployment of BEBs and resulted in a number of transit agencies adopting pure electric buses. To allow access to analysis and reporting on BEBs similar to what is available on FCEBs, CARB has enlisted NREL to conduct a third-party evaluation of the Foothill Transit fleet.

NREL has been evaluating advanced technology buses under funding from DOE and the U.S. Department of Transportation's Federal Transit Administration (FTA). NREL uses a standard data collection and analysis protocol originally developed for DOE heavy-duty vehicle evaluations. The objectives of these evaluations are to provide comprehensive, unbiased evaluation results of advanced technology bus development and performance compared to conventional baseline vehicles.

NREL published the first report on the Foothill Transit BEB fleet in January 2016; that report covered the initial data period of April 2014 to July 2015. ${ }^{1}$ This report provides an update to the previous report with data from August 2015 through December 2016. Data are provided on a selection of compressed natural gas $(\mathrm{CNG})$ buses as a baseline comparison. However, the CNG buses are operated on different routes at higher speeds, which may affect the ability to compare fuel economy results on an apples-to-apples basis.

\section{Fleet Profile-Foothill Transit Agency}

Foothill Transit serves a 327-square-mile area covering the San Gabriel and Pomona Valley region of Los Angeles County. Foothill Transit's administrative office is located in West Covina, California. Foothill Transit is governed by a Joint Powers Authority of 22 member-cities and the County of Los Angeles with representation from the following areas:
Arcadia
Azusa
Baldwin Park
Bradbury
Claremont
Covina
Diamond Bar
Duarte

\footnotetext{
${ }^{1}$ Foothill Transit Battery Electric Bus Demonstration Results, NREL/TP-5400-65274, www.nrel.gov/docs/fy16osti/65274.pdf.
} 


$\begin{array}{ll}\text { El Monte } & \text { Glendora } \\ \text { Industry } & \text { Irwindale } \\ \text { La Puente } & \text { La Verne } \\ \text { Monrovia } & \text { Pasadena } \\ \text { Pomona } & \text { San Dimas } \\ \text { South El Monte } & \text { Temple City } \\ \text { Walnut } & \text { West Covina }\end{array}$

\section{Los Angeles County}

Foothill Transit operates 36 local and express routes including commuter runs to downtown Los Angeles. The current bus fleet consists of $353 \mathrm{CNG}$ buses and 17 BEBs. Figure 1 shows the Foothill Transit service area.

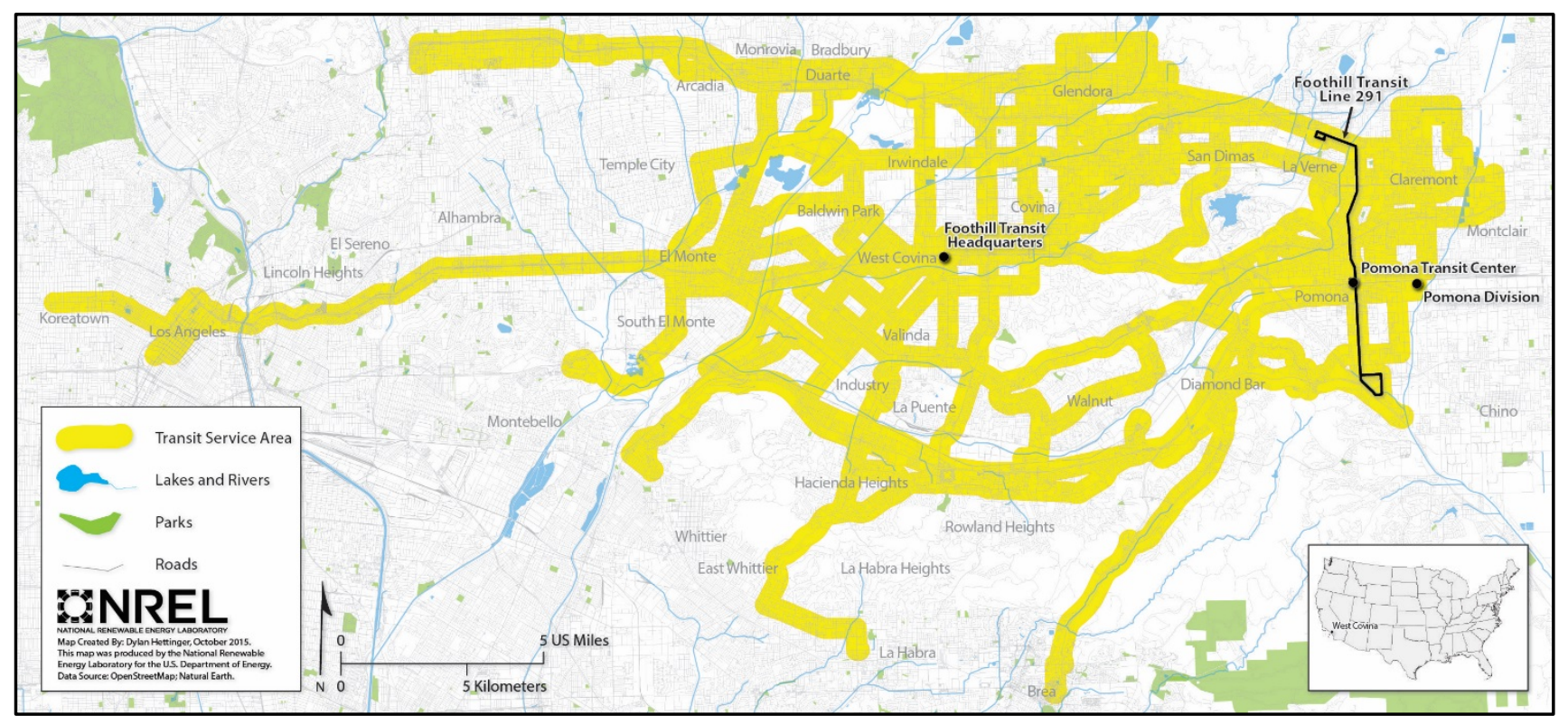

Figure 1. Foothill Transit service area

The agency began a path to cleaner buses in 2002 by adding CNG buses to its fleet. The agency retired its last diesel bus in 2013, making the fleet $100 \%$ alternative fuel. Foothill Transit's commitment to clean and efficient technologies has led the agency to initiate additional projects such as adding photovoltaic panels and making efficiency improvements to its facilities, installing a water-saving bus wash, and purchasing zero-emission BEBs.

Under California's Low Carbon Fuel Standard (LCFS) program, Foothill Transit benefits from operating the BEBs. The state has a goal of reducing the carbon intensity of transportation fuels ten percent by 2020. The LCFS promotes the use of fuels that reduce greenhouse gas emissions. The program uses a market-based credit trading system that allows entities such as Foothill Transit to generate credits for using low carbon fuels or operating ZBuses that can be sold on the open market to regulated parties to meet requirements. Over the study period (Q3 2015-Q4 
2016), Foothill Transit earned approximately $\$ 126,000$ of LCFS credits. Foothill Transit uses the funds generated by selling credits as extra income to use wherever needed. The funds generated vary depending on the current market.

\section{Bus Technology Descriptions}

The BEBs in service at Foothill Transit are 35-foot, composite body buses built by Proterra. In the commercialization process that begins at technology readiness level (TRL) 1-basic research/concept — and ends at TRL 9-commercial deployment, NREL considers the Proterra BEB to be at TRL 7. The design of the bus is a next-generation version based on lessons learned with earlier models and the deployment includes the 12-bus Foothill Transit fleet as well as numerous other fleets around the country. These buses represent a full-scale validation in a relevant environment. (Appendix A provides the TRL guideline table tailored for advanced technology bus commercialization.)

Selecting a comparable baseline bus for a project can be challenging, especially when evaluating a unique design such as the Proterra BEB. Foothill Transit does not operate conventional buses that are similar in size, weight, and year to the BEBs. In addition, the CNG buses are randomly dispatched on all routes whereas the BEBs operate only on a couple of specific local routes. As a result, the BEBs' duty cycle is slower with more stops. The primary baseline buses selected are NABI CNG buses of the same model year as the BEBs. Like the BEBs, the NABI CNG buses are under warranty and should have very low maintenance costs. The NABI CNG buses have Cummins engines with a three-way catalyst. Table 1 provides bus system descriptions for the BEBs and CNG buses that were studied in this evaluation. Figure 2 shows one of the Proterra BEBs and Figure 3 shows one of the NABI CNG baseline buses.

Table 1. Battery Electric and CNG Bus System Descriptions

\begin{tabular}{|c|c|c|}
\hline Vehicle System & BEB & CNG \\
\hline Number of buses & 12 & 8 \\
\hline Bus manufacturer/model & Proterra/BE35 & NABI/BRT-07.03 \\
\hline Model year & 2014 & 2014 \\
\hline Length/width/height & $35 \mathrm{ft} / 102 \mathrm{in} . / 129 \mathrm{in}$. & $42 \mathrm{ft} / 102 \mathrm{in.} / 137 \mathrm{in}$. \\
\hline GVWR/curb weight & $37,320 \mathrm{lb} / 27,680 \mathrm{lb}$ & $42,540 \mathrm{lb} / 33,880 \mathrm{lb}$ \\
\hline Wheelbase & 237 in. & 308 in. \\
\hline Passenger capacity & $\begin{array}{l}35 \text { seats, } 2 \text { wheelchair } \\
\text { positions, } 18 \text { standees }\end{array}$ & $\begin{array}{l}38 \text { seats, } 2 \text { wheelchair } \\
\text { positions, } 10 \text { standees }\end{array}$ \\
\hline Motor or engine & $\begin{array}{l}\text { Permanent magnet, } \\
\text { UQM, PP220 }\end{array}$ & $\begin{array}{c}\text { CNG engine, Cummins, } \\
8.9 \mathrm{ISL} G\end{array}$ \\
\hline Rated power & $220 \mathrm{~kW}$ peak (295 hp) & 280 hp @ 2,200 rpm \\
\hline $\begin{array}{l}\text { Energy storage (BEB) } \\
\text { Fuel capacity (CNG) }\end{array}$ & $\begin{array}{c}\text { Lithium-titanate } \\
\text { batteries, } \\
\text { Altairnano, TerraVolt } \\
368 \text { volts, } 88 \mathrm{kWh} \text { total } \\
\text { energy }\end{array}$ & $\begin{array}{l}7 \text { Type IV cylinders, } \\
22,204 \text { scf at } 3,600 \text { psi }\end{array}$ \\
\hline Accessories & Electric & Mechanical \\
\hline Emissions equipment & $\mathrm{N} / \mathrm{A}$ & 3-way catalyst \\
\hline Transmission/retarder & Regenerative braking & $\mathrm{N} / \mathrm{A}$ \\
\hline Bus purchase cost & $\$ 904,490$ & $\$ 575,000$ \\
\hline
\end{tabular}




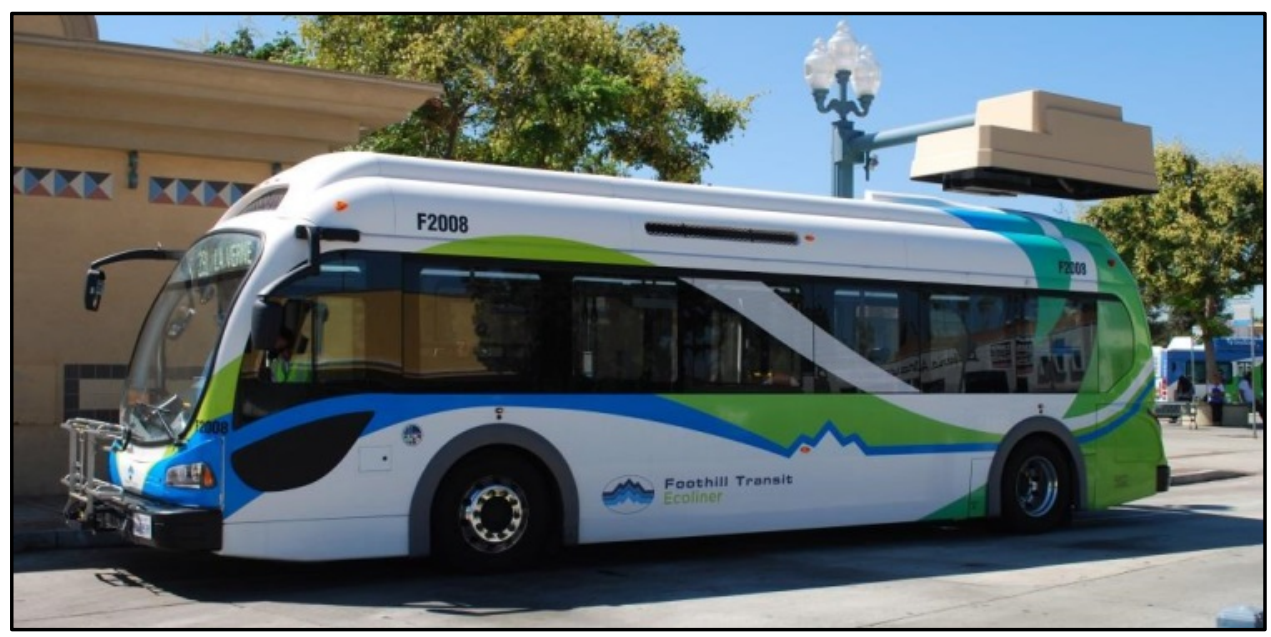

Figure 2. Foothill Transit Proterra BEB

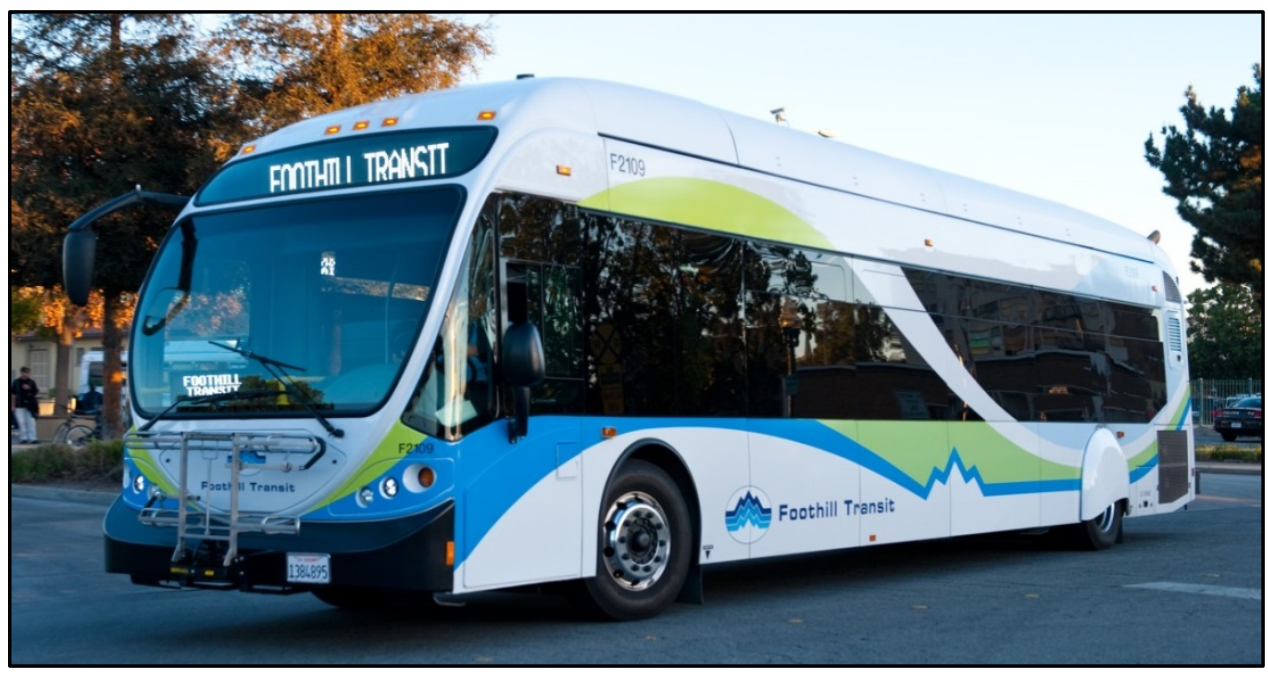

Figure 3. Foothill Transit NABI CNG bus

The warranty for the BEBs is included in the bus purchase cost and covers the following:

- Bumper to bumper-2 years

- Powertrain subsystem-5 years

- Major subsystems - 3 years

- Main structure-12 years

- Battery warranty-6 years.

Foothill purchased the buses in 2013 with delivery in 2014. The purchase cost for BEBs continues to decrease over time. Foothill reports that the per-bus purchase cost for its orders of BEBs has dropped from $\$ 1.2$ million to just under $\$ 800,000$. Table 2 provides costs for the four orders of BEBs for Foothill. Proterra reports that the current base cost of a 40 -foot BEB is approximately $\$ 730,000$ (before taxes). 
Table 2. Foothill Transit's BEB Fleet Purchase Cost (nominal dollars)

\begin{tabular}{|c|c|c|c|c|}
\hline $\begin{array}{c}\text { Order } \\
\text { Number }\end{array}$ & $\begin{array}{c}\text { Number } \\
\text { of Buses }\end{array}$ & Bus Description & $\begin{array}{c}\text { Purchase } \\
\text { Year }\end{array}$ & $\begin{array}{c}\text { Cost per } \\
\text { Bus }\end{array}$ \\
\hline 1 & 3 & 35-ft BE35 fast charge buses & 2009 & $\$ 1,200,000$ \\
\hline 2 & 12 & 35-ft BE35 fast charge buses & 2013 & $\$ 904,490$ \\
\hline 3 & 2 & $40-f t$ Catalyst fast charge buses & 2014 & $\$ 825,000$ \\
\hline 4 & 13 & $40-f t$ Catalyst extended range buses & 2015 & $\$ 789,000$ \\
\hline
\end{tabular}

\section{Charging and Maintenance Facilities}

The BEBs and CNG buses are operated out of Foothill Transit's Pomona Operations and Maintenance Facility. Foothill Transit provides operation and maintenance of its fleet through contracts with private firms. Maintenance staff at the division handle all maintenance work on the CNG buses and cover safety inspections, general bus maintenance, and some preventive maintenance for the BEBs. Proterra has two on-site technicians that handle all warranty work on the BEBs. At the end of each day, operators typically charge the BEBs at the Pomona Transit Center (PTC) prior to returning to the depot. Foothill Transit uses an in-depot charger at the operations and maintenance facility for times when a bus needs charging after a going through maintenance or repairs. The installation of this in-depot charger was the only modification needed to allow maintenance of the BEBs inside the facility. A new in-depot charger costs $\$ 50,000$. Proterra reports that the cost of these chargers continues to drop since adopting the industry standard charger protocol (SAE J1772). Foothill Transit also added a fast charger to this facility at a cost of $\$ 665,000$ (charger and installation).

\section{Fast-Charge Station}

Foothill Transit's fast-charge station is located at the PTC. The station consists of a climate controlled building that holds two Eaton $500 \mathrm{~kW}$ chargers, with two charge heads located on opposite sides of the building. The two chargers operate as separate units with a dedicated control system for each. A common communication network serves both units with sensors to detect which charge head a bus is approaching to enable proper bus-to-charger communication for docking. Emergency shut-off switches for each charge head are located on both sides of the building. Figure 4 shows the fast-charge station with two BEBs at the charging heads. The building that houses the chargers and equipment is in the center. 


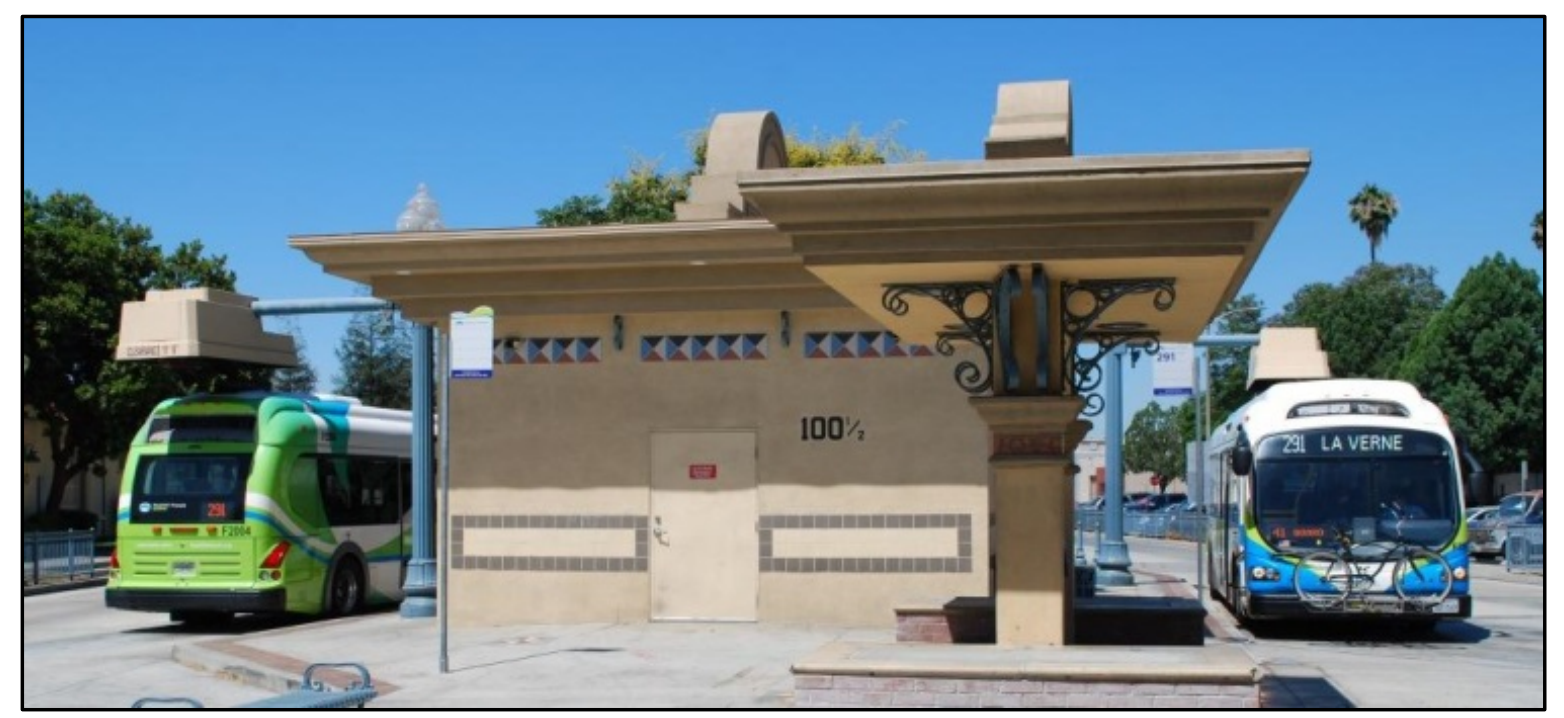

Figure 4. BEB charging station at the PTC

The system can charge two buses simultaneously. Docking a bus with the charging head occurs semi-autonomously and the operator does not have to exit the bus to make any connections. The system is designed to fully charge a bus in less than ten minutes. For Foothill Transit's Line 291, typical charge times are around seven minutes. Foothill Transit built a layover time into the schedule to allow enough time for charging. Foothill Transit has a contract with Proterra to maintain the chargers and associated equipment. The cost for this service is $\$ 1,500$ per month. The agency is adding another fast charger at the Azusa Intermodal Transit Center. The new charging station will allow the agency to expand the service of the BEBs to additional routes.

Foothill Transit reports that its experience with the charging station has been exceptional and there have been very few issues. Since the project began, the buses have been charged 119,150 times. Because the station has two separate charging heads, there was no time when the buses could not operate. The availability of the two charging heads has been $98 \%$ and $99 \%$ since the beginning of the project. The biggest challenge was avoiding the higher electricity demand charges that would go into effect if two buses were being charged simultaneously. Proterra solved this issue through a software modification.

\section{In-Service Operations Evaluation Results}

The previous report included data from April 2014 through July 2015. The results presented in this section focus on data from August 2015 through December 2016. During the latest data period, the BEBs operated 501,037 miles over 58,497 hours of operation. This indicates an overall operational speed of $8.6 \mathrm{mph}$. (Appendix B provides a summary of data for this report data period and for the entire in-service period. Appendix $\mathrm{C}$ provides a data summary in metric units. Appendix D includes graphs for each evaluation metric that encompasses all data from the beginning of the evaluation.)

\section{Route Assignments}

Foothill Transit's BEB fleet operates out of its Pomona Operations and Maintenance Facility. The service consists of 21 routes: fifteen local and six commuter/express routes. The agency 
operates the BEB fleet primarily on Line 291. This line is a 16.1-mile route that travels between La Verne and Pomona with minimal deadhead distance from the Pomona depot. The line serves a transit dependent community and has high ridership. The route loops through the PTC in both directions, making the PTC an ideal location for the fast charger system. Figure 5 shows the route map for Line 291.

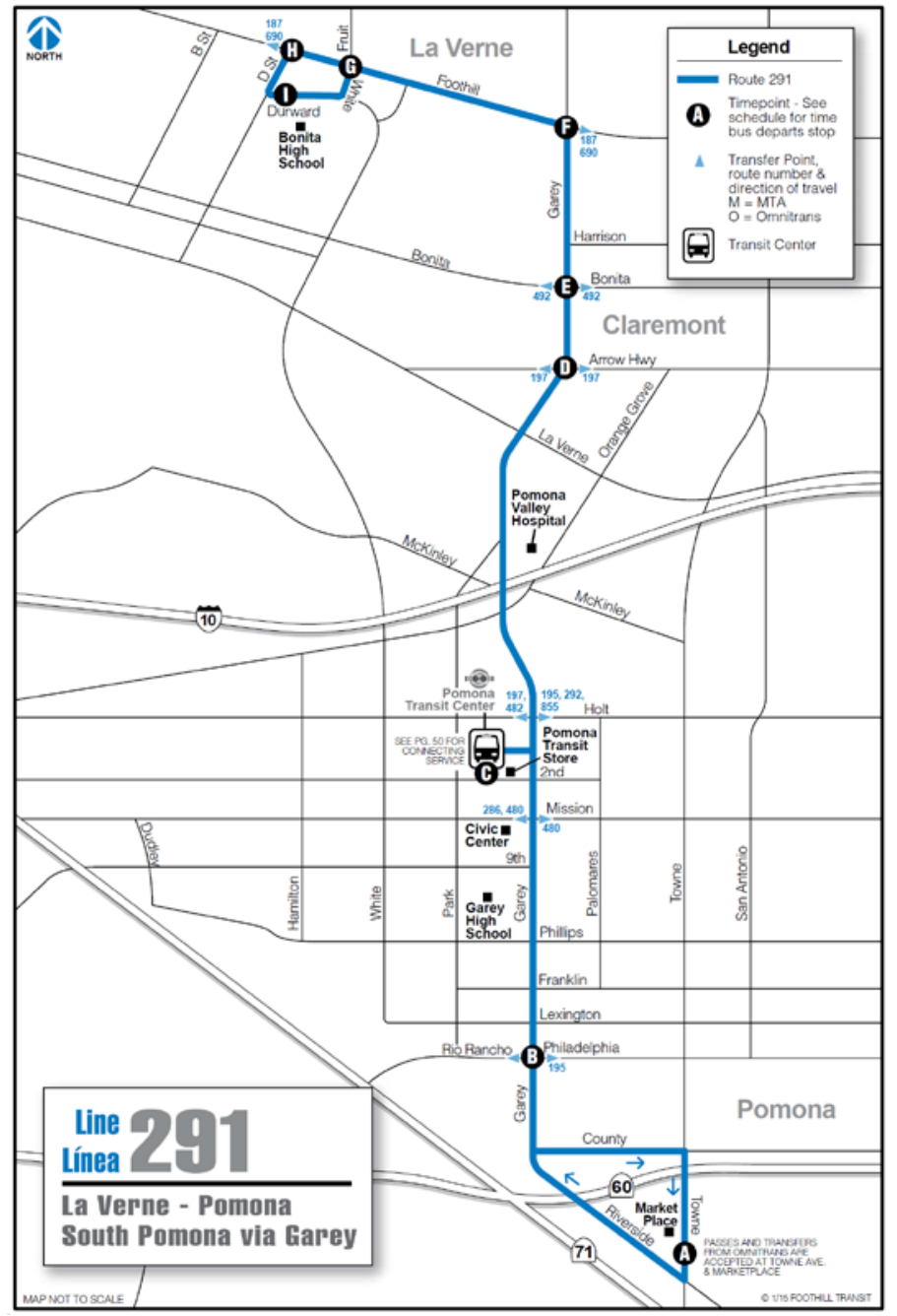

Figure 5. Route map for Line 291 (courtesy of Foothill Transit)

Based on Foothill Transit's schedule for the Pomona operations, in-service speed for Line 291 is $10.6 \mathrm{mph}$. The agency also operates the BEBs on Line 855 on most mornings. Line 855 runs through the PTC where the charger is located. The BEBs are not operated on Line 855 during the afternoons because those route blocks include service on commuter routes, which is beyond the current range of the buses. The CNG baseline buses are randomly dispatched on all of the routes out of the Pomona operations including commuter routes. Average in-service speed for the Pomona operations as a whole is $17.6 \mathrm{mph}$. Figure 6 outlines the difference in route assignment between the BEBs and the CNG buses. The routes serviced by the CNG buses include commuter routes that result in a higher average speed and greater mileage accumulation than for local 
routes. Because fuel economy is highly dependent on duty cycle, this has a significant impact on the fleet-average fuel economy discussed later in this report.

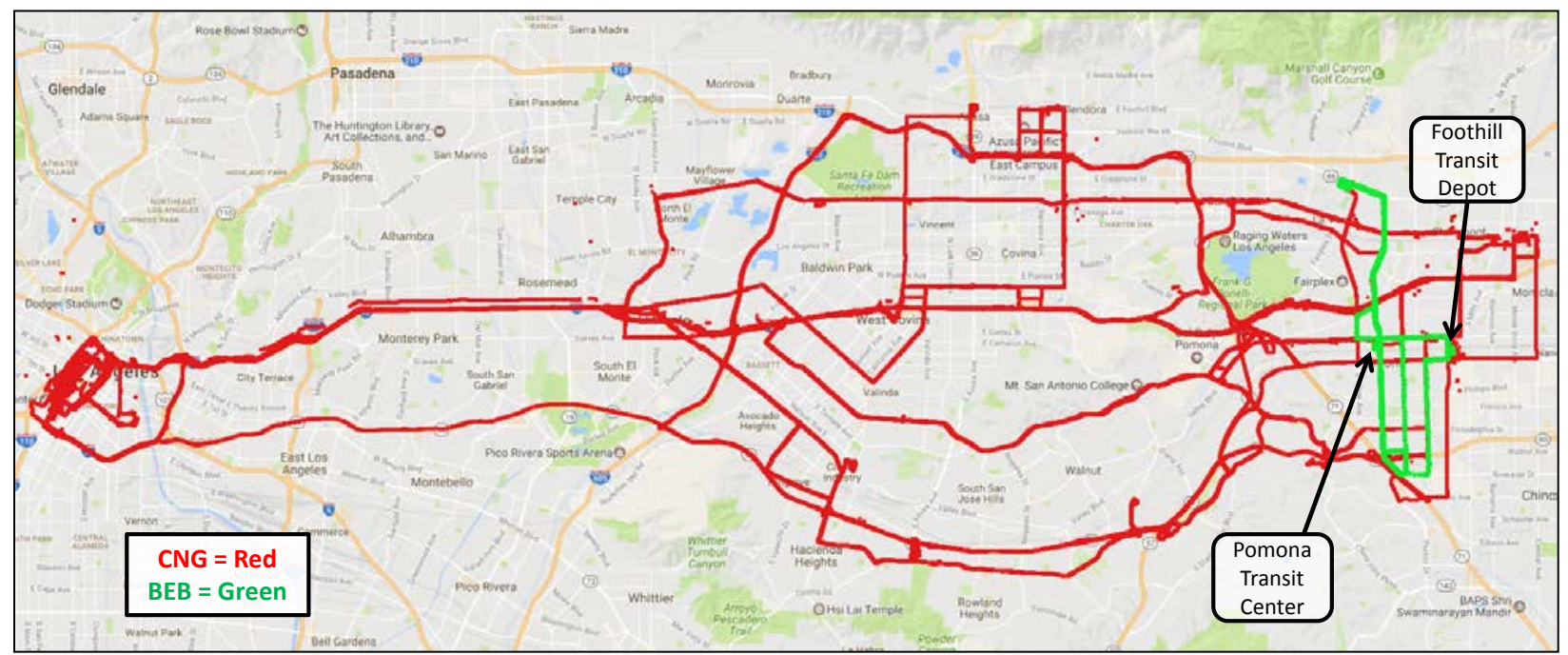

Figure 6. Routes traveled by randomly-dispatched CNG buses (red) and Line 291 traveled by the BEBs (green)

\section{Bus Use and Availability}

Bus use and availability are indicators of reliability. Lower bus usage may indicate downtime for maintenance or purposeful reduction of planned work for the buses. This section summarizes bus usage and availability for the BEBs and baseline buses.

Table 3 summarizes the average monthly mileage for the BEBs and CNG baseline buses for the data period. The average monthly operating mileage per bus for the BEBs during the evaluation period is 2,456 miles, which is about half that of the CNG buses. This is expected, considering that the BEBs are operated primarily on Line 291 and the CNG buses are randomly dispatched on all routes out of the Pomona facility, including express and commuter routes that have much higher average speeds. The results presented in this report are based on the planned route for the buses and do not indicate a specific limitation of the technology. Figure 7 tracks the monthly average miles for the BEBs and CNG buses for the data period. 
Table 3. Average Monthly Mileage (Evaluation Period)

\begin{tabular}{|c|c|c|c|}
\hline Bus & $\begin{array}{c}\text { Total } \\
\text { Mileage }\end{array}$ & Months & $\begin{array}{l}\text { Average } \\
\text { Monthly } \\
\text { Mileage }\end{array}$ \\
\hline \multicolumn{4}{|c|}{ BEB Fleet } \\
\hline 2004 & 42,067 & 17 & 2,475 \\
\hline 2005 & 46,987 & 17 & 2,764 \\
\hline 2006 & 44,742 & 17 & 2,632 \\
\hline 2007 & 43,321 & 17 & 2,548 \\
\hline 2008 & 43,666 & 17 & 2,569 \\
\hline 2009 & 45,078 & 17 & 2,652 \\
\hline 2010 & 42,448 & 17 & 2,497 \\
\hline 2011 & 42,710 & 17 & 2,512 \\
\hline 2012 & 39,896 & 17 & 2,347 \\
\hline 2013 & 36,719 & 17 & 2,160 \\
\hline 2014 & 40,384 & 17 & 2,376 \\
\hline 2015 & 33,021 & 17 & 1,942 \\
\hline BEB Total & 501,039 & 204 & 2,456 \\
\hline \multicolumn{4}{|c|}{ CNG Fleet } \\
\hline 2200 & 77,696 & 17 & 4,570 \\
\hline 2201 & 83,182 & 17 & 4,893 \\
\hline 2202 & 82,718 & 17 & 4,866 \\
\hline 2203 & 84,575 & 17 & 4,975 \\
\hline 2204 & 73,490 & 17 & 4,323 \\
\hline 2205 & 82,498 & 17 & 4,853 \\
\hline 2206 & 84,474 & 17 & 4,969 \\
\hline 2207 & 87,766 & 17 & 5,163 \\
\hline CNG Total & 656,399 & 136 & 4,826 \\
\hline
\end{tabular}

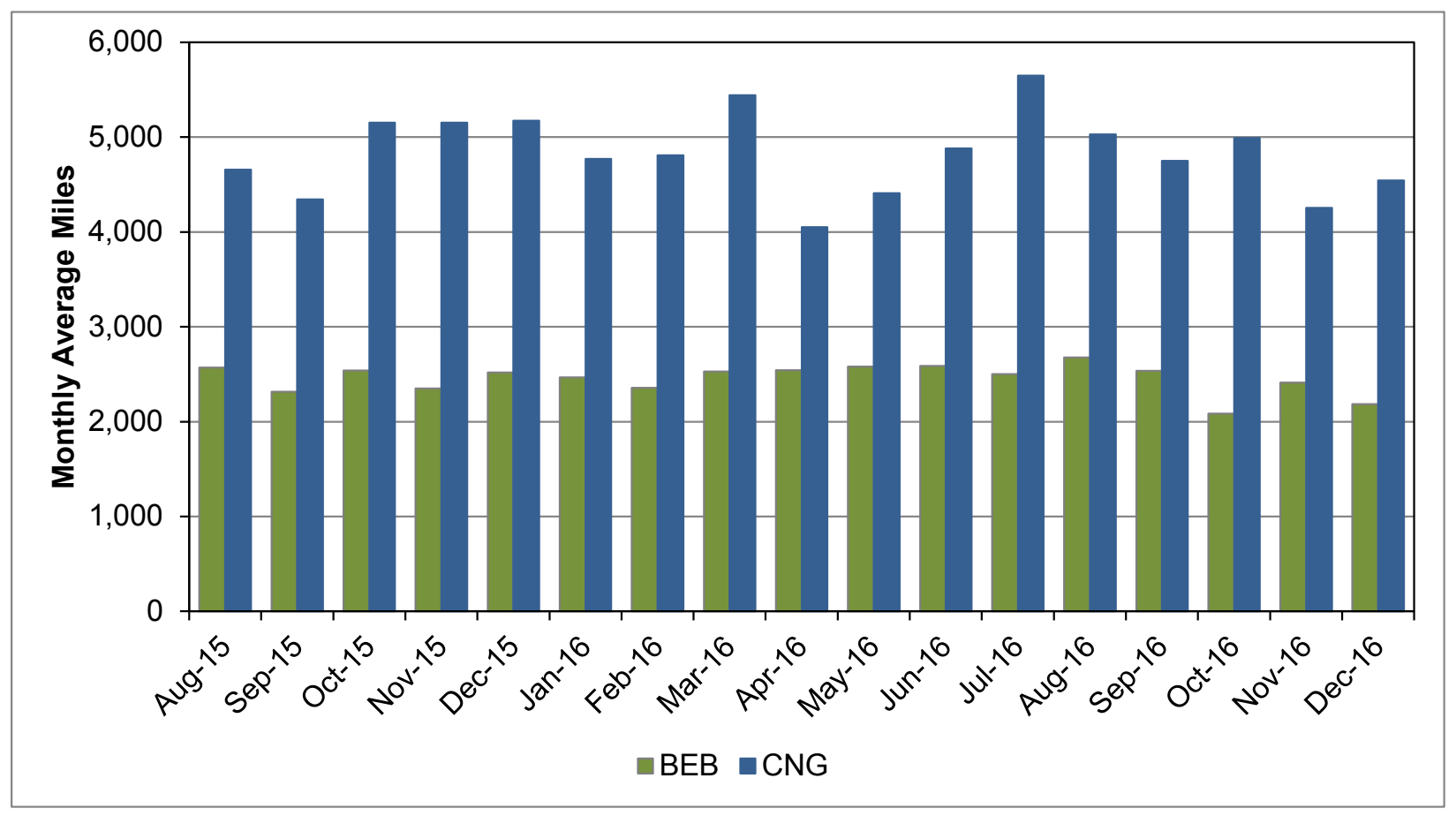

Figure 7. Monthly average miles for the Foothill Transit BEBs and CNG buses 
Another measure of reliability is availability - the percentage of days the buses are actually available out of days that the buses are planned for operation. The data presented are based on availability for morning pull-out and don't necessarily reflect all-day availability. Transit agencies typically have a target of $85 \%$ availability for their fleets to allow for time to handle scheduled and unscheduled maintenance. For the Foothill Transit fleet, the buses are planned to operate every day, including weekends. To calculate availability, NREL collected data from several sources. One source was the daily service reports that Proterra provides to Foothill Transit. These reports list the availability of each BEB for that day and outline any reasons for unavailability. Foothill Transit was able to provide approximately $83 \%$ of the daily service reports; this is considered to be a sufficient sample size to be representative of the total. Foothill Transit also provided the daily garage activity sheets for the Pomona facility, which list each bus that is not available for morning pull-out and provide a general reason for unavailability. These activity sheets are for the depot as a whole and include the BEBs as well as the CNG buses. This was the only source of availability data for the $\mathrm{CNG}$ buses. The garage activity sheets were not available for every day. During the data period, $61 \%$ of the activity sheets were available. Because these are new conventional technology buses, the CNG bus availability is expected to be high. With two data sources for the BEBs, NREL was able to account for more days in the analysis when compared to the CNG buses. As a result, the total planned days for the two fleets is not the same.

Table 4 summarizes the availability for the BEBs during the data period. The per-bus availability ranges from a high of $96 \%$ to a low of $84 \%$. The overall average for the group is $90 \%$.

Table 4. Summary of Availability by Bus for the BEBs

\begin{tabular}{|c|c|c|c|}
\hline Bus & $\begin{array}{c}\text { Planned } \\
\text { Days }\end{array}$ & $\begin{array}{c}\text { Available } \\
\text { Days }\end{array}$ & $\begin{array}{c}\text { Percent } \\
\text { Availability }\end{array}$ \\
\hline 2004 & 408 & 375 & 92 \\
\hline 2005 & 408 & 376 & 92 \\
\hline 2006 & 408 & 383 & 94 \\
\hline 2007 & 408 & 373 & 91 \\
\hline 2008 & 408 & 352 & 86 \\
\hline 2009 & 408 & 392 & 96 \\
\hline 2010 & 408 & 350 & 86 \\
\hline 2011 & 408 & 384 & 94 \\
\hline 2012 & 408 & 372 & 91 \\
\hline 2013 & 408 & 351 & 86 \\
\hline 2014 & 408 & 354 & 87 \\
\hline 2015 & 408 & 344 & 84 \\
\hline Total BEB & $\mathbf{4 , 8 9 5}$ & $\mathbf{4 , 4 0 6}$ & 90 \\
\hline
\end{tabular}

Figure 8 tracks the monthly availability for the BEBs (green line) and CNG buses (blue line) for the data period. The figure also provides an indication of the reasons for unavailability for the BEBs. The stacked bars for each month show the number of days the BEBs were not available by six categories. General bus system issues caused the majority of downtime for the BEBs, followed by electric drive system issues. The major drop in availability at the end of the data 
period was due to issues with three buses: one was involved in an accident and the other two had transmission repairs. The availability of the CNG buses dropped during the months of April and May 2016, and again in December 2016. The downtime during the first of those periods was due to accident repair for one of the baseline buses. The December 2016 downtime was primarily for engine work on three of the baseline buses.

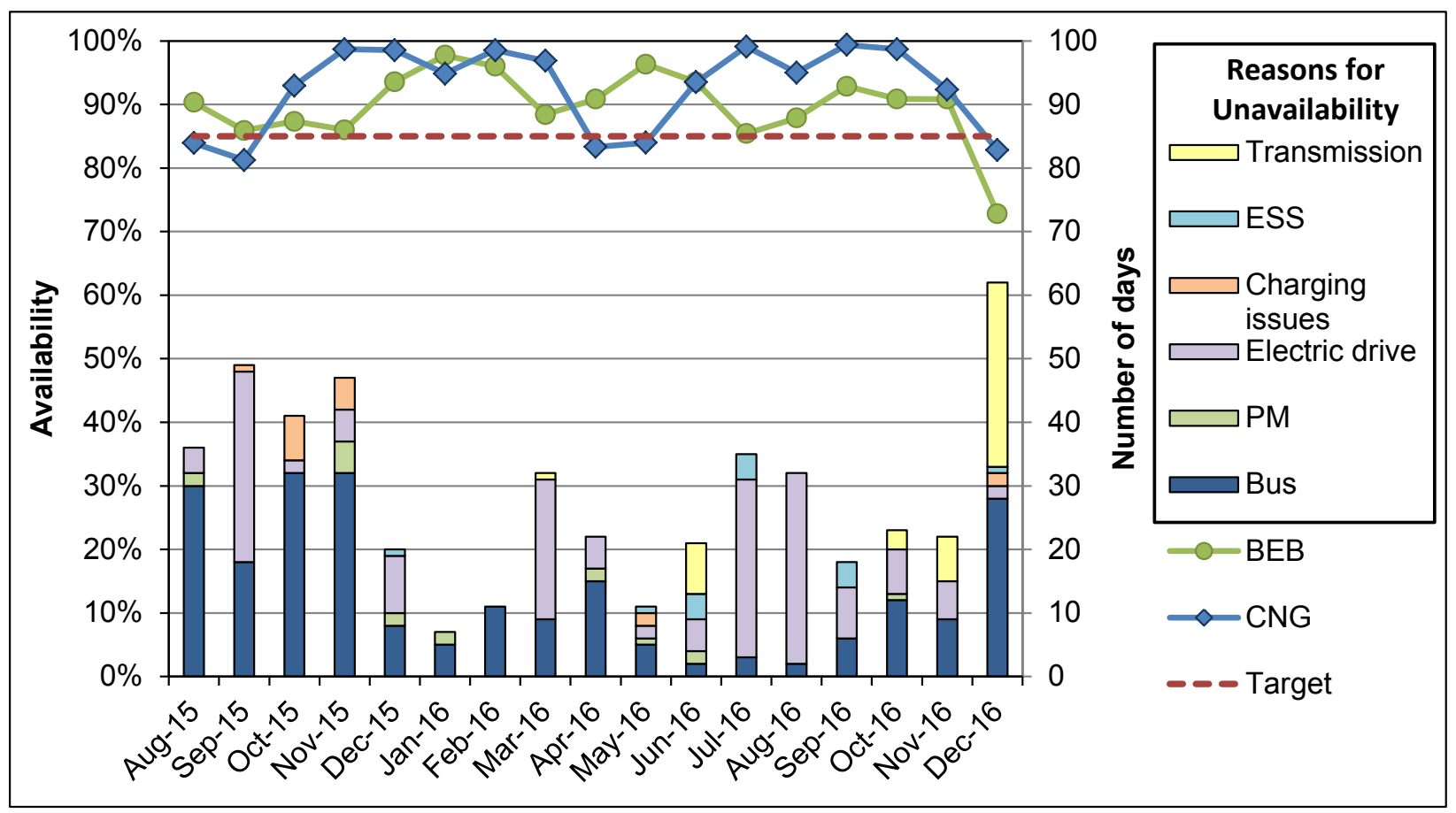

Figure 8. Availability for the BEBs and CNG buses

Table 5 summarizes the reasons for unavailability for the BEBs and CNG buses. During this reporting period, the average availability was $90 \%$ for the BEBs and $93 \%$ for the CNG buses. Figure 9 graphically presents the availability for the BEBs and Figure 10 presents the availability for the CNG buses.

Table 5. Summary of Availability and Unavailability of Buses for Service

\begin{tabular}{|l|c|c|c|c|}
\hline \multicolumn{1}{|c|}{ Category } & $\begin{array}{c}\text { BEB } \\
\text { \# Days }\end{array}$ & $\begin{array}{c}\text { BEB } \\
\%\end{array}$ & $\begin{array}{c}\text { CNG } \\
\text { \# Days }\end{array}$ & $\begin{array}{c}\text { CNG } \\
\%\end{array}$ \\
\hline Planned work days & 4,895 & & 2,512 & \\
\hline Days available & 4,406 & 90.0 & 2,326 & 92.6 \\
\hline Unavailable & $\mathbf{4 8 9}$ & $\mathbf{1 0 . 0}$ & $\mathbf{1 8 6}$ & $\mathbf{7 . 4}$ \\
\hline ESS & 15 & 0.3 & - & - \\
\hline CNG engine & - & - & 28 & 1.1 \\
\hline Electric drive & 165 & 3.4 & - & - \\
\hline Charging issues & 17 & 0.3 & - & - \\
\hline Preventive maintenance & 17 & 0.3 & 17 & 0.7 \\
\hline General bus maintenance & 227 & 4.6 & 136 & 5.4 \\
\hline Transmission & 48 & 1.0 & 5 & 0.2 \\
\hline
\end{tabular}




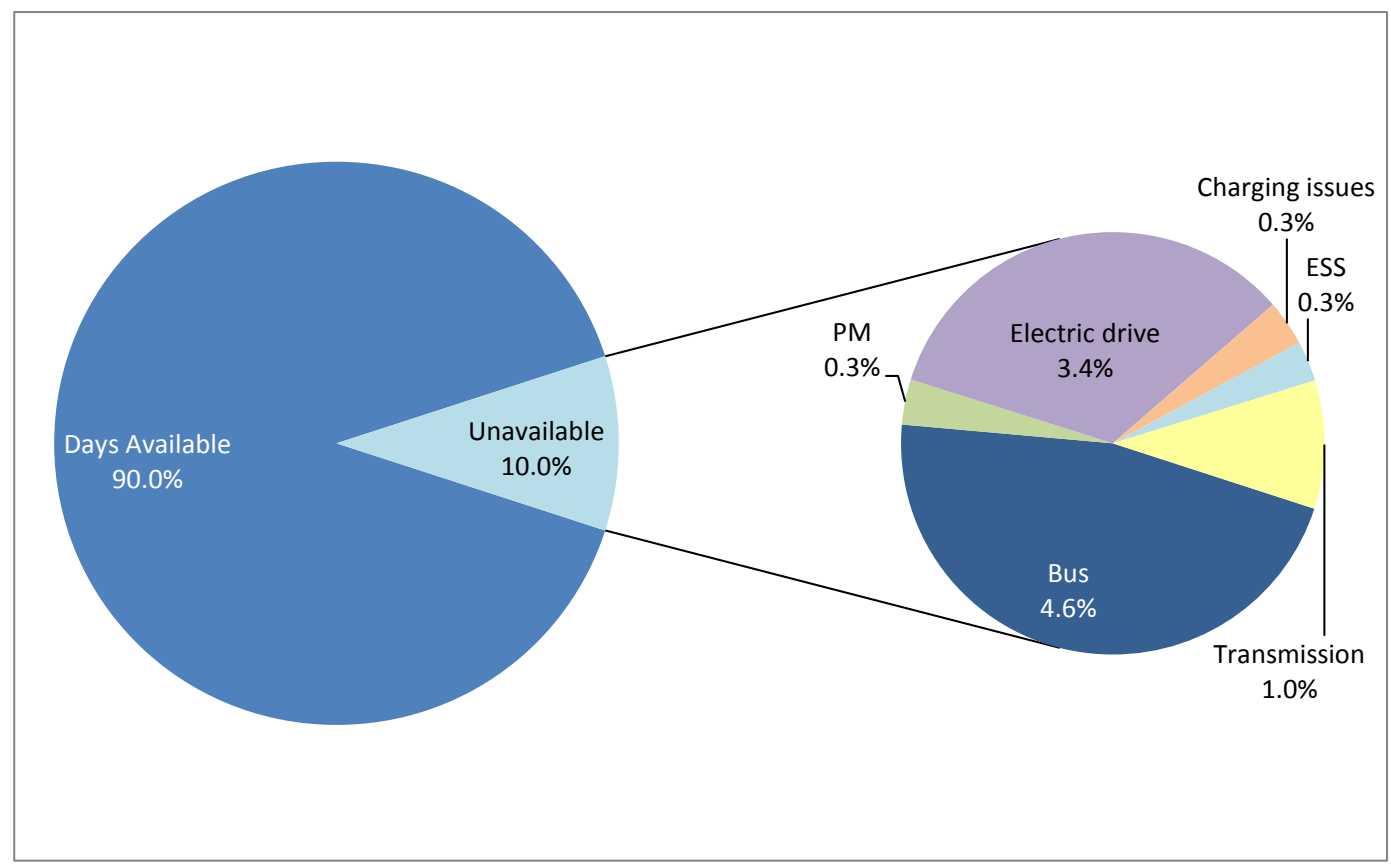

Figure 9. Reasons for unavailability for the Foothill Transit BEBs

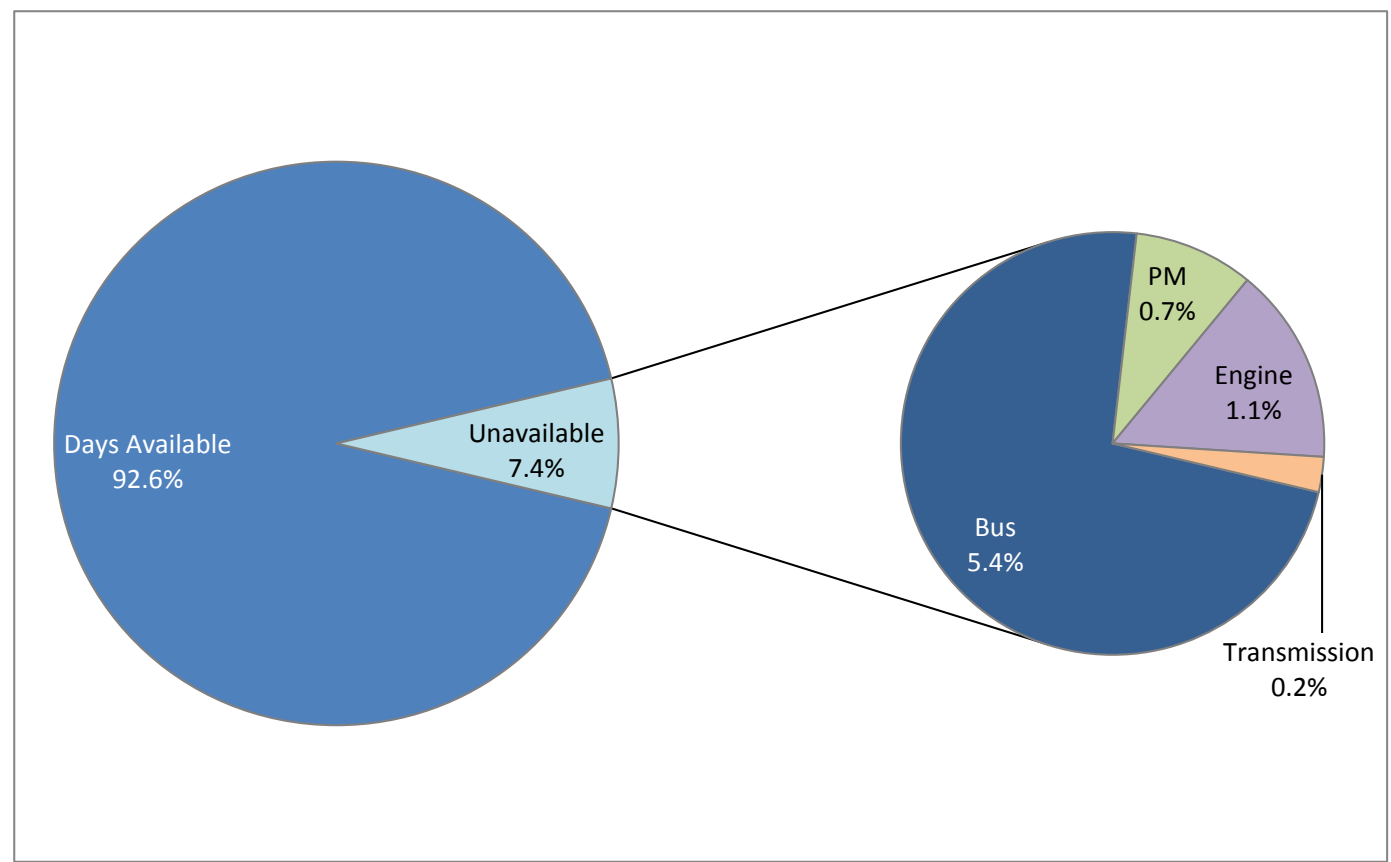

Figure 10. Reasons for unavailability for the Foothill Transit CNG buses 


\section{Energy Use, Fuel Economy, and Cost}

Each BEB is typically charged every time it stops at the PTC. Figure 11 shows the total energy used and number of charges for the BEB fleet by month. During the data period, the fleet averaged $63,957 \mathrm{kWh}$ and 3,335 charges per month.

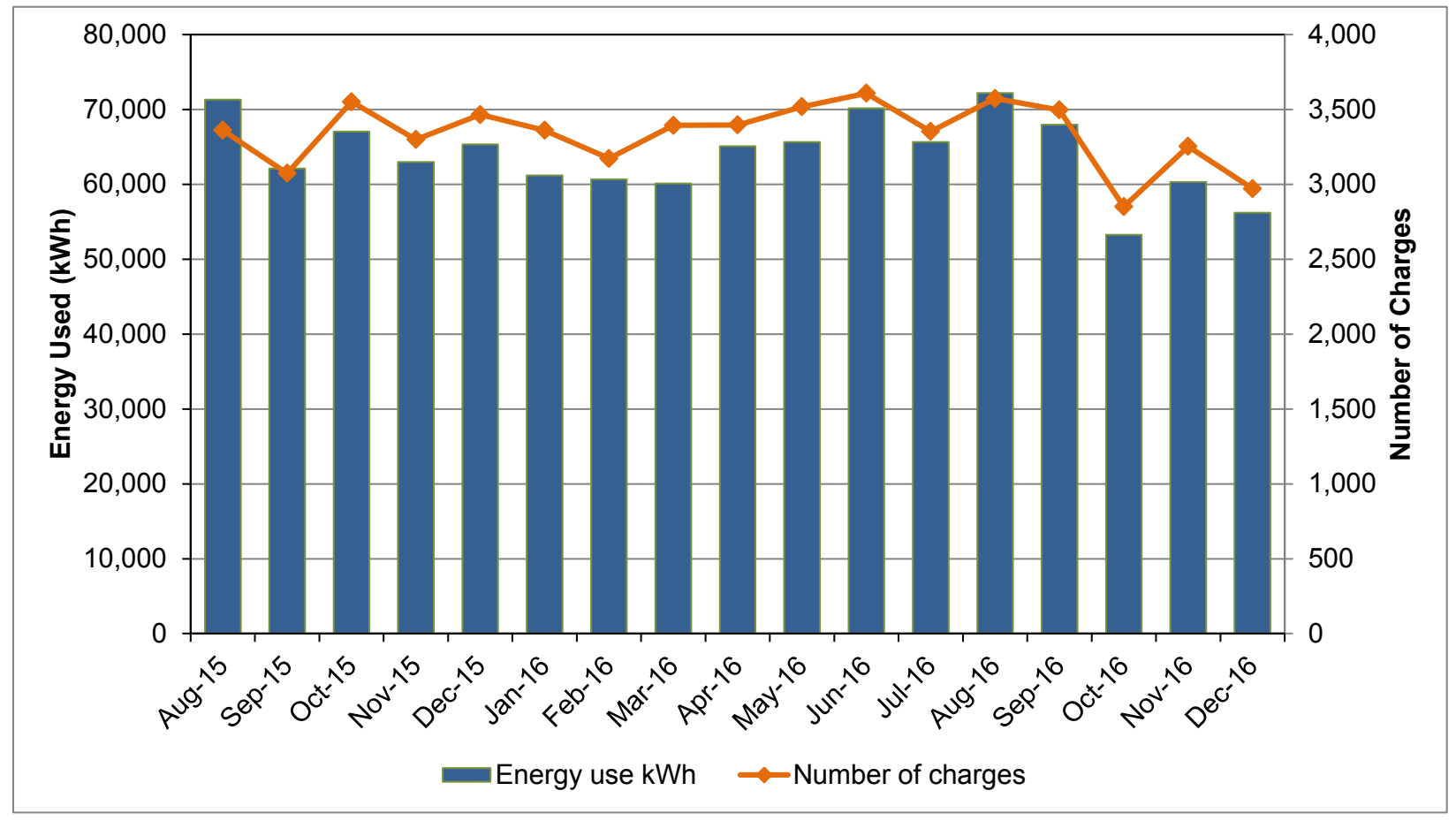

Figure 11. Monthly energy use and number of charges for the BEB fleet

Proterra records and stores data—including total $\mathrm{kWh}$, number of charges, and miles driven - on each of the buses. These data were provided to NREL for calculating efficiency of the buses in $\mathrm{kWh}$ per mile. Foothill Transit's CNG buses are normally fueled once each day. Foothill Transit provided individual fueling records for the CNG buses. CNG is typically tracked in units of gasoline gallon equivalent (gge). NREL used these records to calculate the CNG fuel economy in miles per gasoline gallon equivalent (mpgge) as well as miles per diesel gallon equivalent (mpdge). To compare the BEBs to the baseline buses, NREL converted the $\mathrm{kWh}$ to diesel gallon equivalent (dge) using a conversion factor of $37.7 \mathrm{kWh} / \mathrm{gallon}$. The explanation of the energy conversion from $\mathrm{kWh}$ of electricity to dge appears at the end of Appendix B. (Appendices B and $\mathrm{C}$ contain summary statistics for the BEBs and CNG buses.)

Table 6 shows electricity and CNG fuel consumption and equivalent fuel economy for the study buses during the reporting period. The BEBs had an overall average efficiency of $2.17 \mathrm{kWh}$ per mile, which equates to 17.35 mpdge. The CNG buses had an average fuel economy of 3.89 mpgge, which equates to 4.34 mpdge. These results are for the fleets as Foothill Transit operates them, with the CNG buses at a higher average speed compared to the BEBs. 
Table 6. Energy Use and Fuel Economy² (Evaluation Period)

\begin{tabular}{|c|c|c|c|c|c|}
\hline Bus & $\begin{array}{c}\text { Mileage } \\
\text { (fuel base) }\end{array}$ & $\begin{array}{l}\text { Electricity } \\
\text { (kWh) or } \\
\text { CNG (gge) }\end{array}$ & $\begin{array}{c}\text { kWh per Mile } \\
\text { or Miles per } \\
\text { gge } \\
\end{array}$ & $\begin{array}{c}\text { Diesel Gallon } \\
\text { Equivalent } \\
\text { (mpdge) }\end{array}$ & $\begin{array}{l}\text { Fuel } \\
\text { Economy } \\
\text { (mpdge) }\end{array}$ \\
\hline \multicolumn{6}{|c|}{ BEB Fleet } \\
\hline 2004 & 42,067 & 91,699 & 2.18 & 2,435 & 17.28 \\
\hline 2005 & 46,987 & 103,707 & 2.21 & 2,754 & 17.06 \\
\hline 2006 & 44,742 & 100,057 & 2.24 & 2,657 & 16.84 \\
\hline 2007 & 43,321 & 96,698 & 2.23 & 2,568 & 16.87 \\
\hline 2008 & 43,666 & 95,169 & 2.18 & 2,527 & 17.28 \\
\hline 2009 & 45,078 & 96,680 & 2.14 & 2,567 & 17.56 \\
\hline 2010 & 42,448 & 90,619 & 2.13 & 2,406 & 17.64 \\
\hline 2011 & 42,710 & 89,831 & 2.10 & 2,386 & 17.90 \\
\hline 2012 & 39,896 & 86,664 & 2.17 & 2,301 & 17.34 \\
\hline 2013 & 36,719 & 72,131 & 1.96 & 1,915 & 19.17 \\
\hline 2014 & 40,384 & 86,123 & 2.13 & 2,287 & 17.66 \\
\hline 2015 & 33,021 & 77,898 & 2.36 & 2,069 & 15.96 \\
\hline BEB Total & 501,037 & $1,087,276$ & 2.17 & 28,873 & 17.35 \\
\hline \multicolumn{6}{|c|}{ CNG Fleet } \\
\hline 2200 & 74,775 & 18,808 & 3.98 & 16,833 & 4.44 \\
\hline 2201 & 77,607 & 21,230 & 3.66 & 19,001 & 4.08 \\
\hline 2202 & 79,295 & 19,955 & 3.97 & 17,860 & 4.44 \\
\hline 2203 & 83,726 & 21,965 & 3.81 & 19,659 & 4.26 \\
\hline 2204 & 70,939 & 18,219 & 3.89 & 16,306 & 4.35 \\
\hline 2205 & 81,630 & 20,135 & 4.05 & 18,021 & 4.53 \\
\hline 2206 & 81,940 & 21,520 & 3.81 & 19,261 & 4.25 \\
\hline 2207 & 85,006 & 21,535 & 3.95 & 19,274 & 4.41 \\
\hline CNG Total & 634,918 & 163,367 & 3.89 & 146,215 & 4.34 \\
\hline
\end{tabular}

Figure 12 shows monthly average fuel economy for the BEBs and CNG buses in mpdge. The monthly average high temperature is included in the graph to track any seasonal variations in the fuel economy due to heating or cooling of the bus, which would require additional energy.

\footnotetext{
${ }^{2}$ Average speed for the BEBs was $10.7 \mathrm{mph}$ compared to $17.9 \mathrm{mph}$ average speed for the CNG buses.
} 


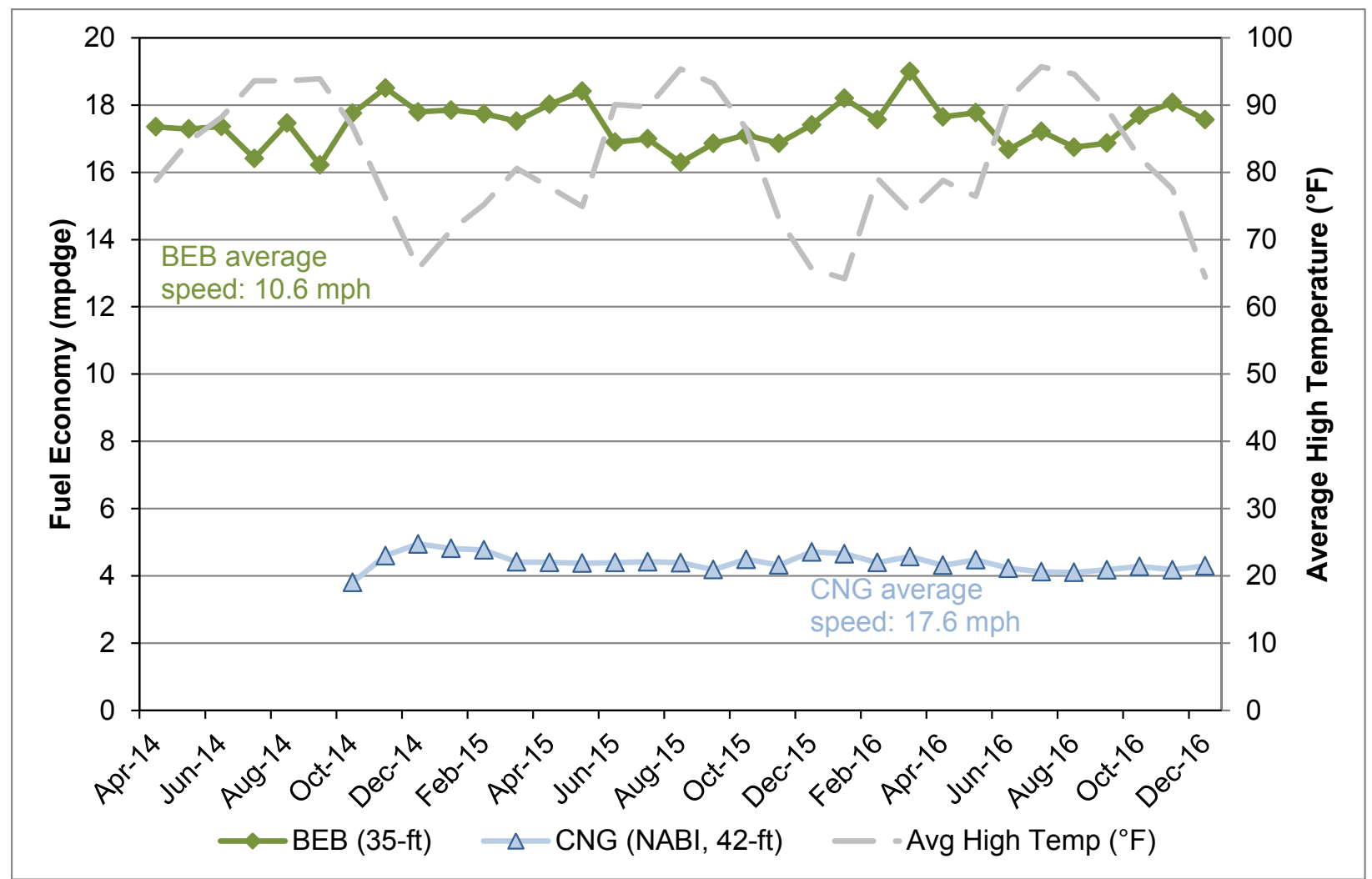

Figure 12. Monthly average fuel economy for the BEBs and CNG buses

\section{Challenge of Comparing Technologies with Different Duty Cycles}

The operating duty cycle of a bus has a significant effect on fuel economy. Because Foothill Transit operates its BEB and CNG bus fleets differently, the efficiency results presented above are not considered an apples-to-apples comparison. NREL works with its fleet partners to characterize their experience with advanced technology and does not request changes to the agency's planned operation. Because of this, a perfect comparison is not always possible.

As mentioned in the previous report, researchers on NREL's Fleet Test and Evaluation team were funded by DOE to collect and analyze detailed data on the BEBs to understand the overall use and effectiveness of the BEBs in transit fleet operations compared to operations of conventional counterparts in the same location. The results of the BEB drive cycle analysis were included in the previous report. To characterize the difference in duty cycle between the BEBs and conventional technology buses, the NREL Fleet Test and Evaluation team temporarily instrumented $12 \mathrm{CNG}$ buses at Foothill Transit with data loggers to record detailed in-service drive cycle data in February and March of 2016. This data set contains more than 37,000 miles logged during a total of 212 days of bus operation. Foothill Transit randomly dispatched the instrumented CNG buses on routes throughout the Pomona service area. The data loggers also recorded two days of CNG operation on Line 291 to provide a direct comparison to the BEBs in this evaluation. This collaboration with the DOE-funded activity offers a unique opportunity to make a better comparison of efficiency between the BEB and CNG buses.

Figure 13 shows the daily average $\mathrm{CNG}$ fuel economy as a function of daily average driving speed from this detailed data set. Driving speed includes only the time a bus was in motion; it 
does not include bus stop or layover time but does include deadhead driving. On Line 291, the average CNG fuel economy was $2.1 \mathrm{mpdge}$ and the average driving speed was $18.1 \mathrm{mph}$. The average CNG fuel economy for all other routes traveled in this data set was 3.5 mpdge and the average driving speed was $29.0 \mathrm{mph}$. Although only two days of CNG operation on Line 291 were recorded, the results follow the general correlation between driving speed and fuel economy.

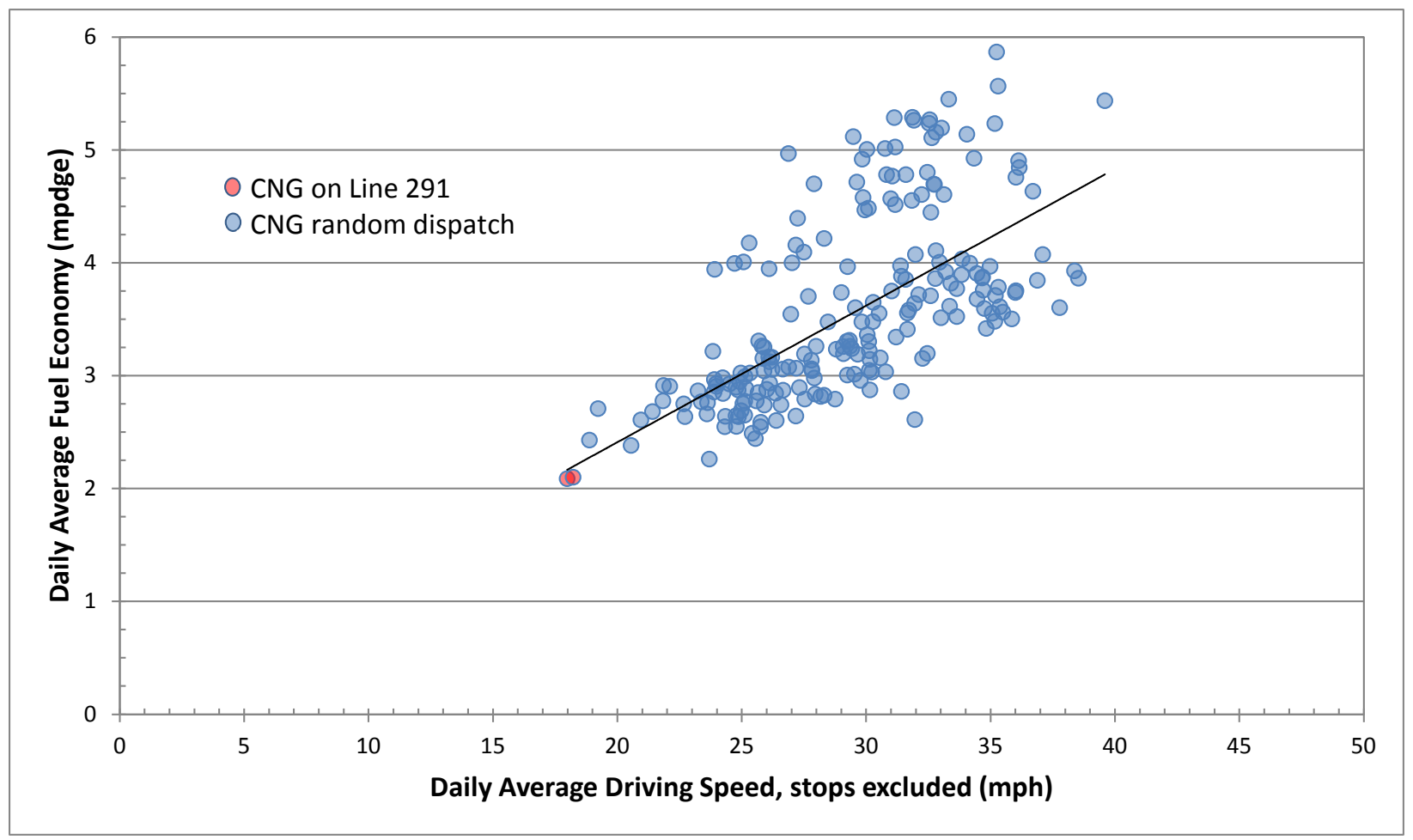

Figure 13. Fuel economy vs. average driving speed for the instrumented CNG buses

Table 7 provides a comparison of duty cycle and fuel economy for the BEBs and CNG buses using both fleet data and logged data. The table includes overall average speed (including stopped time) and average driving speed (without stops). The average driving speed (logged) for the BEBs and CNG buses is similar, indicating a more accurate comparison for fuel economy. When comparing the logged data, the BEB fuel economy is more than 8 times higher than that of a CNG bus operating exclusively on Line 291. The difference in overall average speed between the BEBs and CNG buses is likely due to the increased dwell time needed to charge the BEBs. 
Table 7. Fuel Economy Comparison

\begin{tabular}{|l|c|c|c|c|}
\hline \multicolumn{1}{|c|}{ Bus Type } & Line & $\begin{array}{c}\text { Average } \\
\text { Speed, } \\
\text { including stops } \\
\text { (mph) }\end{array}$ & $\begin{array}{c}\text { Average } \\
\text { Driving Speed, } \\
\text { excluding } \\
\text { stops (mph) }\end{array}$ & $\begin{array}{c}\text { Fuel } \\
\text { Economy } \\
\text { (mpdge) }\end{array}$ \\
\hline BEB (fleet) & 291,855 & 10.6 & - & 17.35 \\
\hline BEB (logged) & 291,855 & 7.0 & 17.8 & 17.48 \\
\hline CNG (fleet) & Random dispatch & 17.6 & - & 4.34 \\
\hline CNG (logged) & 291 & 9.5 & 18.1 & 2.09 \\
\hline CNG (logged) & Random dispatch & 19.2 & 29.0 & 3.49 \\
\hline
\end{tabular}

The remainder of this report presents the results from the BEBs and baseline buses in this evaluation as they are currently operated by Foothill Transit in real revenue service. Other transit agencies interested in deploying BEBs will likely take a similar approach of first operating BEBs on a shorter, local route before expanding BEB service.

\section{Fuel Cost and Charging Efficiency}

Foothill Transit's charging station was installed with a separate utility meter. Foothill Transit provided the monthly utility bills to NREL to determine the energy cost. Time of use and demand charges factor into the cost of electricity for Foothill Transit. When the first three BEBs were deployed, Proterra and Foothill Transit were concerned that the maximum demand would exceed $500 \mathrm{~kW}$. Each of the fast chargers at the Pomona Transit Center is rated at $500 \mathrm{~kW}$, allowing the possibility of exceeding the $500 \mathrm{~kW}$ threshold. Customers that exceed the $500 \mathrm{~kW}$ limit are moved onto an industrial schedule (TOU $-8^{3}$ ), which has high demand charges. This would result in much higher costs for the agency. Proterra petitioned the California Public Utilities Commission to help address this issue for Foothill Transit and other transit agencies considering fast-charge buses. The California Public Utilities Commission issued resolution E-4514, ${ }^{4}$ which allowed Foothill Transit to stay on the small commercial schedule (TOU-GS-1) that has no demand charges. Typically, this rate schedule is only applicable to customers that demand less than $20 \mathrm{~kW}$. That exemption expired at the end of 2015.

Southern California Edison has established additional rate schedules specifically for customers using electric vehicles. TOU-EV-4 ${ }^{5}$ is applicable to customers whose monthly demand is between $20 \mathrm{~kW}$ and $500 \mathrm{~kW}$. Foothill Transit worked with Proterra to implement charge management software that controls the charging demand to stay under the $500 \mathrm{~kW}$ threshold. The combination of rate schedule and charge management resulted in a lower electricity cost for the agency in the most recent data period. Table 8 shows the costs for Foothill Transit during both data periods.

\footnotetext{
${ }^{3}$ https://www.sce.com/NR/sc3/tm2/pdf/ce54-12.pdf

4 http://docs.cpuc.ca.gov/publisheddocs/published/g000/m032/k702/32702823.pdf

5 https://www.sce.com/NR/sc3/tm2/pdf/ce141-12.pdf
} 
Table 8. Foothill Transit Electric Costs

\begin{tabular}{|l|c|c|}
\hline Rate Schedule & $\begin{array}{c}\text { TOU-GS-1 } \\
\text { Exemption }\end{array}$ & $\begin{array}{c}\text { TOU-EV-4 } \\
\text { With Charge } \\
\text { Management }\end{array}$ \\
\hline Period & $4 / 14-12 / 15$ & $1 / 16-12 / 16$ \\
\hline Cost/kWh $(\$)$ & $\$ 0.175$ & $\$ 0.170$ \\
\hline Cost/mi $(\$)$ & $\$ 0.44$ & $\$ 0.42$ \\
\hline
\end{tabular}

During this reporting period, the electricity price averaged $\$ 0.17$ per $\mathrm{kWh}$. Based on energy used by the buses, the energy cost for the BEB fleet calculates to $\$ 0.37$ per mile. When taking into account the actual amount of electricity Foothill Transit purchased from the utility, the cost is $\$ 0.41$ per mile. The difference of approximately $10 \%$ reflects the energy lost during charging.

Foothill Transit pays different electricity rates for summer and winter months. During the reporting period, the average price was $\$ 0.15$ per $\mathrm{kWh}$ for the winter months (October-May) and $\$ 0.20$ per $\mathrm{kWh}$ for the summer months (June-September). These electricity rates resulted in average energy costs of $\$ 0.37$ per mile and $\$ 0.52$ per mile during the winter and summer, respectively.

The CNG fuel cost during the reporting period averaged $\$ 0.96$ per gge, which calculates to $\$ 0.25$ per mile for the NABI CNG buses as operated by Foothill Transit (average speed $17.6 \mathrm{mph}$ ). Figure 14 shows the monthly average energy cost per mile for the BEBs and CNG buses, as well as the monthly average high temperature. The gray sections indicate the summer months during which Foothill Transit pays higher seasonal electricity rates. The electricity rates were the primary cause of the increases in per-mile energy costs for the BEBs during the summer. Permile fuel costs for the $\mathrm{CNG}$ buses remained relatively stable during the reporting period. For comparison, the chart includes an estimate of the cost per mile for the CNG buses if they operated only on Line 291. NREL used the monthly miles for the baseline CNG buses and calculated fuel use with the fuel economy logged from the CNG bus on Line 291. The lower fuel economy would increase the cost to an overall average of $\$ 0.50$ per mile, which is higher than the cost of the BEB fleet. Because of the seasonal rates for electricity, the cost per mile for the BEBs is lower during the winter months and higher in the summer. 


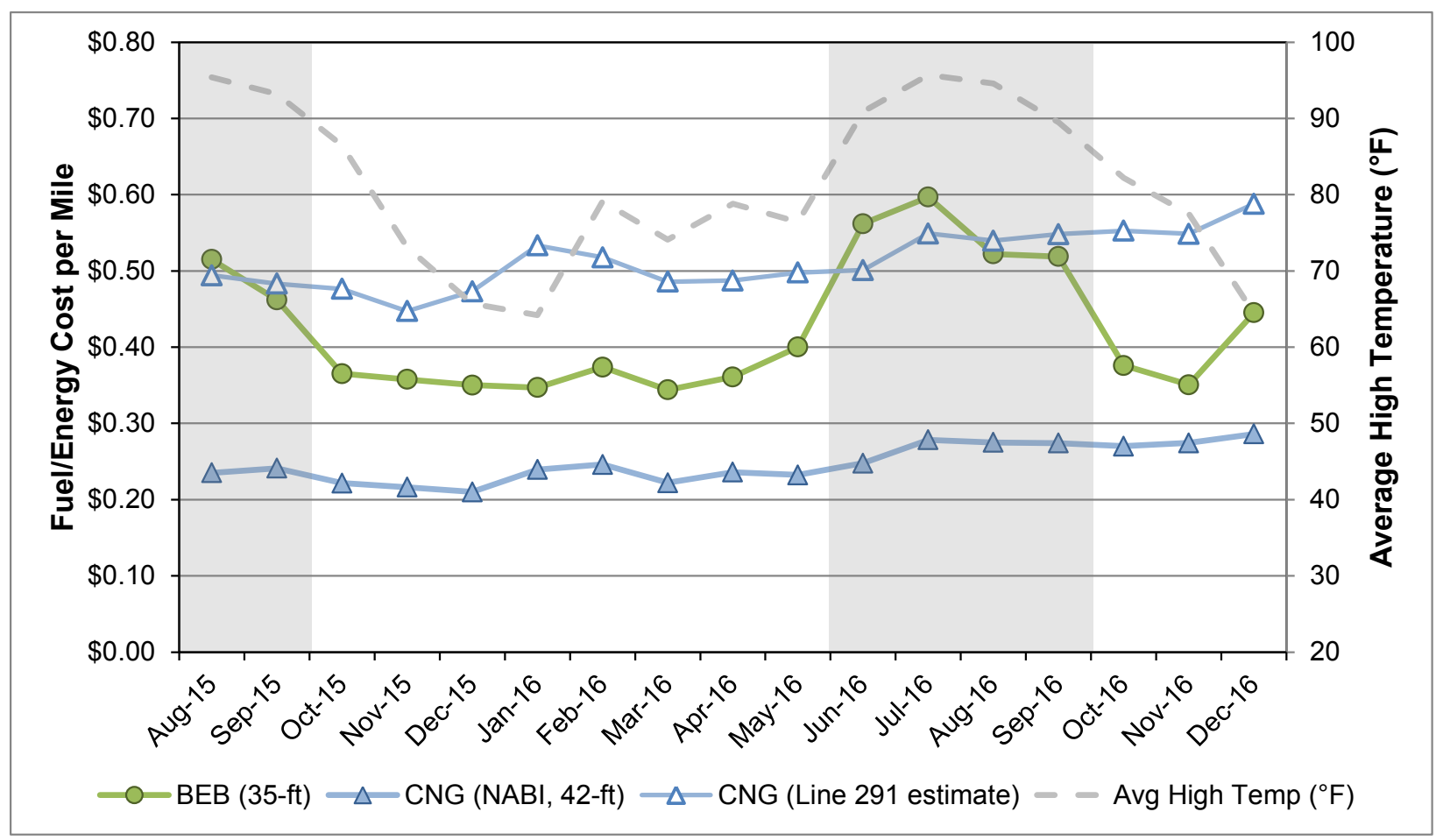

Figure 14. Monthly average energy cost per mile for the BEBs and CNG buses

Figure 15 shows the overall monthly charging efficiency for the BEBs based on the total energy consumption of the fleet (recorded by the buses) and the total energy purchased for the charging station (per the utility bills). These monthly totals are based on the utility billing periods and do not exactly match the calendar months. The overall charging efficiency is normally between $88 \%$ and $90 \%$. September 2016 results were omitted from the chart due to insufficient data. 


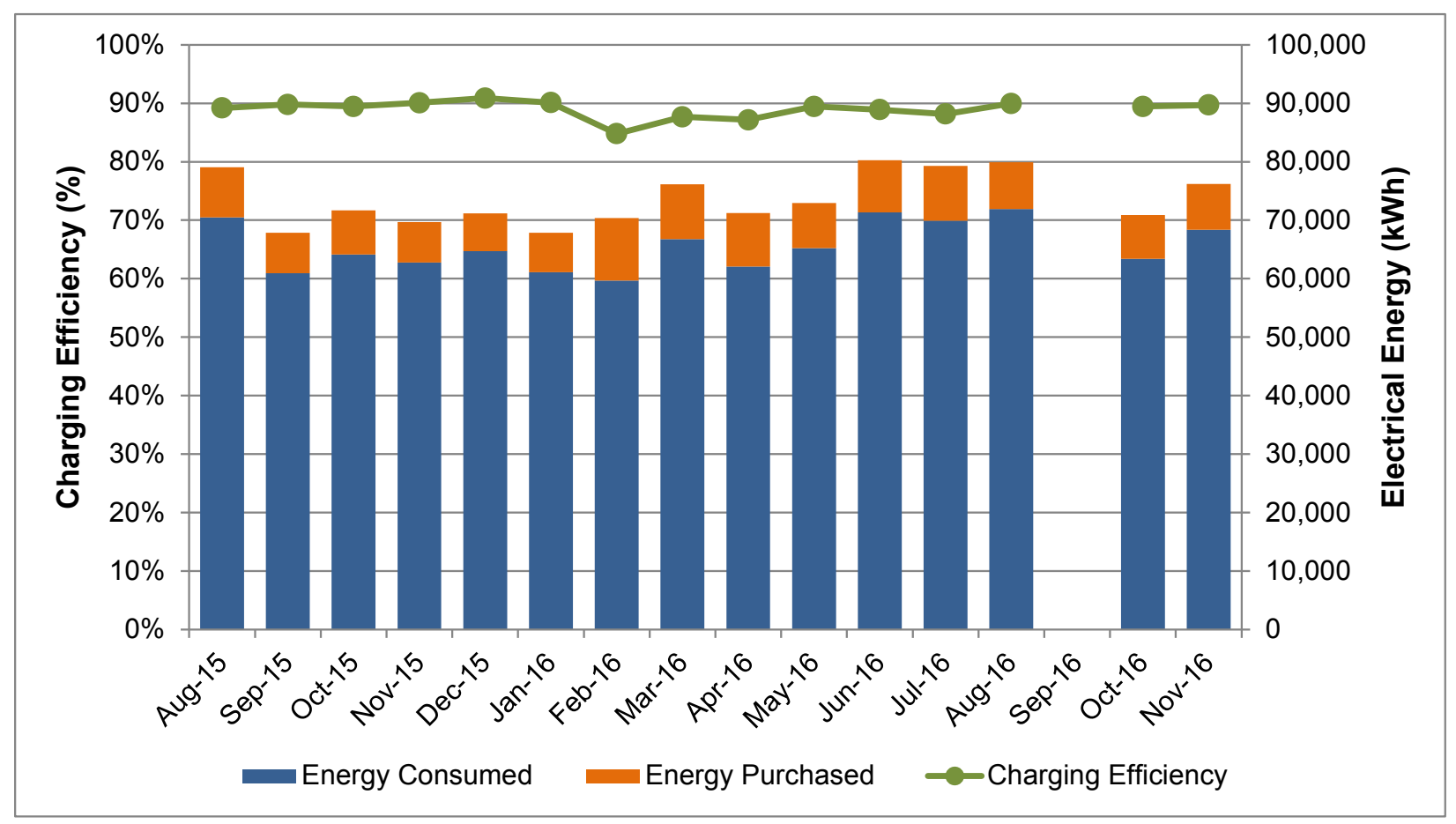

Figure 15. Monthly energy consumption and overall charging efficiency for the BEBs

\section{Roadcall Analysis}

A roadcall or revenue vehicle system failure (as named in the National Transit Database ${ }^{6}$ ) is defined as a failure of an in-service bus that causes the bus to be replaced on route or causes a significant delay in schedule. If the problem with the bus can be repaired during a layover and the schedule is kept, this is not considered a roadcall. The analysis described here includes only roadcalls that were caused by "chargeable" failures. Chargeable roadcalls include systems that can physically disable the bus from operating on route, such as interlocks (doors, air system), engine, or things that are deemed to be safety issues if operation of the bus continues. They do not include roadcalls for things such as problems with radios, fareboxes, or destination signs.

The transit industry measures reliability as mean distance between failures, also documented as miles between roadcalls (MBRC). Table 9 provides the MBRC for the BEBs and CNG buses categorized by bus roadcalls, propulsion-related roadcalls, and ESS-related roadcalls.

Propulsion-related roadcalls include all roadcalls due to propulsion-related systems including the battery system (or engine for a conventional bus), electric drive, fuel, exhaust, air intake, cooling, non-lighting electrical, and transmission systems. The ESS-related roadcalls and MBRC are included for the BEBs. This roadcall analysis includes data accumulated since the clean point of April 2014.

\footnotetext{
${ }^{6}$ National Transit Database website: www.ntdprogram.gov/ntdprogram/.
} 
Table 9. Roadcalls and MBRC (from Clean Point)

\begin{tabular}{|l|c|c|}
\hline & BEB & CNG \\
\hline Dates & $4 / 14-12 / 16$ & $10 / 14-12 / 16$ \\
\hline Mileage & 902,281 & $1,020,772$ \\
\hline Average miles accumulated per bus & 75,190 & 127,597 \\
\hline Bus roadcalls & 146 & 35 \\
\hline Bus MBRC & 6,180 & 29,165 \\
\hline Propulsion-related roadcalls & 55 & 18 \\
\hline Propulsion-related MBRC & 16,405 & 56,710 \\
\hline ESS-related roadcalls & 3 & \\
\hline ESS-related MBRC & 300,760 & \\
\hline
\end{tabular}

Figure 16 presents the cumulative MBRC by category for the BEBs and CNG baseline buses. DOE and FTA have not established performance targets specific to BEBs, but the MBRC targets established for $\mathrm{FCEBs}^{7}$ were based on typical conventional buses and the targets could be considered appropriate for any advanced technology. The ultimate target for bus MBRC $(4,000)$ is included in the upper plot of Figure 16 as a red dashed line. The ultimate target for fuel-cellsystem-related MBRC is 20,000. This is considered comparable to roadcalls for BEBs that are related to the battery, or ESS. The ESS MBRC target is shown as a red dashed line in the lower plot of Figure 16. At this stage of demonstration, the Foothill Transit BEBs have achieved an ESS MBRC that is significantly higher than the target.

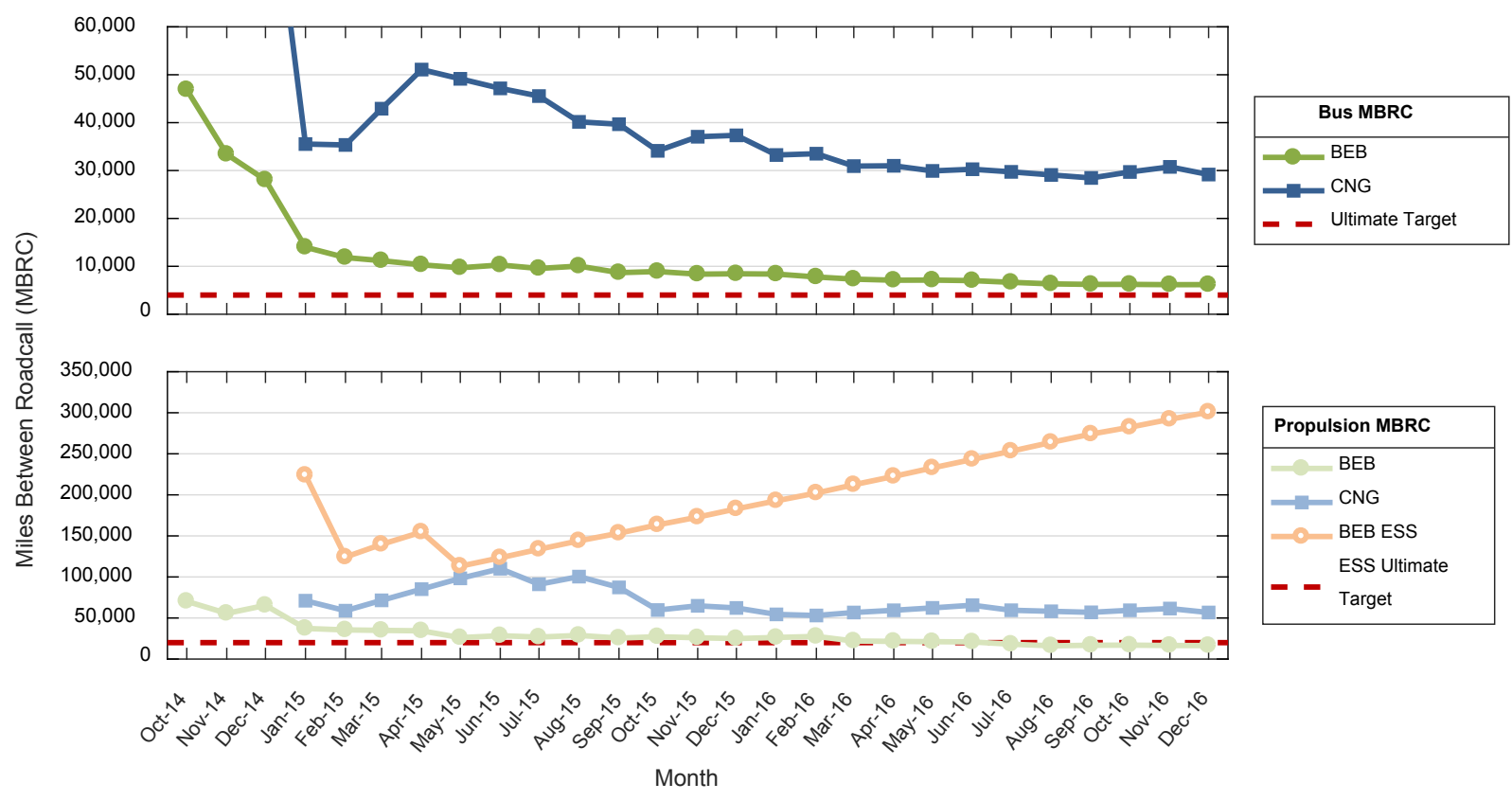

Figure 16. Cumulative MBRC for the BEBs and CNG buses

\footnotetext{
${ }^{7}$ Fuel Cell Technologies Program Record \# 12012, Sept. 2012, www.hydrogen.energy.gov/pdfs/12012_fuel_cell_bus_targets.pdf.
} 


\section{Maintenance Analysis}

NREL collected all work orders for the study buses for this evaluation. Costs for accident-related repair, which are extremely variable from bus to bus, were eliminated from the analysis for both BEB and CNG bus fleets. Warranty costs were also removed from the cost-per-mile calculations. For consistency, NREL uses a constant maintenance labor rate of \$50 per hour; this does not reflect an average rate for Foothill Transit. This section first covers total maintenance costs and then maintenance costs by bus system.

At the beginning of the project, Proterra technicians performed all maintenance on the BEBs. In January 2015, the Foothill Transit contractor staff took over the preventive maintenance inspections (PMI) and general bus work. This has remained constant throughout the report data period.

\section{Total Work Order Maintenance Costs}

Total maintenance costs include the price of parts and labor rates at $\$ 50$ per hour. Cost per mile is calculated as follows:

$$
\text { Cost per mile }=[(\text { labor hours } * 50)+\text { parts cost }] / \text { mileage }
$$

Table 10 shows total maintenance costs for the BEBs and CNG buses. Scheduled and unscheduled maintenance cost per mile is provided for each bus and study group of buses. During the reporting period, the BEBs had a maintenance cost per mile that was slightly lower (4.9\% less) than that of the CNG buses. 
Table 10. Total Work Order Maintenance Costs (Evaluation Period)

\begin{tabular}{|c|c|c|c|c|c|c|}
\hline Bus & Mileage & Parts (\$) & $\begin{array}{l}\text { Labor } \\
\text { Hours }\end{array}$ & $\begin{array}{l}\text { Total Cost } \\
\text { per Mile } \\
\text { (\$) }\end{array}$ & $\begin{array}{l}\text { Scheduled } \\
\text { Cost per } \\
\text { Mile (\$) }\end{array}$ & $\begin{array}{l}\text { Unscheduled } \\
\text { Cost per Mile } \\
\text { (\$) }\end{array}$ \\
\hline \multicolumn{7}{|c|}{ BEB Fleet } \\
\hline 2004 & 42,067 & $\$ 5,428.16$ & 101.2 & $\$ 0.25$ & $\$ 0.07$ & $\$ 0.18$ \\
\hline 2005 & 46,987 & $\$ 3,407.96$ & 87.4 & $\$ 0.17$ & $\$ 0.07$ & $\$ 0.10$ \\
\hline 2006 & 44,742 & $\$ 4,676.79$ & 106.8 & $\$ 0.22$ & $\$ 0.07$ & $\$ 0.15$ \\
\hline 2007 & 43,321 & $\$ 4,695.32$ & 104.2 & $\$ 0.23$ & $\$ 0.07$ & $\$ 0.16$ \\
\hline 2008 & 43,666 & $\$ 5,446.82$ & 93.0 & $\$ 0.23$ & $\$ 0.07$ & $\$ 0.16$ \\
\hline 2009 & 45,078 & $\$ 2,889.02$ & 104.7 & $\$ 0.18$ & $\$ 0.07$ & $\$ 0.11$ \\
\hline 2010 & 42,448 & $\$ 2,744.76$ & 100.1 & $\$ 0.18$ & $\$ 0.07$ & $\$ 0.11$ \\
\hline 2011 & 42,710 & $\$ 4,575.00$ & 92.9 & $\$ 0.22$ & $\$ 0.07$ & $\$ 0.15$ \\
\hline 2012 & 39,896 & $\$ 2,053.03$ & 115.7 & $\$ 0.20$ & $\$ 0.07$ & $\$ 0.13$ \\
\hline 2013 & 36,719 & $\$ 1,462.05$ & 82.7 & $\$ 0.15$ & $\$ 0.07$ & $\$ 0.08$ \\
\hline 2014 & 40,384 & $\$ 4,395.14$ & 100.8 & $\$ 0.23$ & $\$ 0.07$ & $\$ 0.17$ \\
\hline 2015 & 33,021 & $\$ 3,814.02$ & 76.4 & $\$ 0.23$ & $\$ 0.06$ & $\$ 0.17$ \\
\hline Average $B E B$ & 41,753 & $\$ 3,799.01$ & 97 & $\$ 0.21$ & $\$ 0.07$ & $\$ 0.14$ \\
\hline \multicolumn{7}{|c|}{ CNG Fleet } \\
\hline 2200 & 77,696 & $\$ 14,027.80$ & 177.9 & $\$ 0.30$ & $\$ 0.12$ & $\$ 0.17$ \\
\hline 2201 & 83,182 & $\$ 8,275.39$ & 182.0 & $\$ 0.21$ & $\$ 0.11$ & $\$ 0.10$ \\
\hline 2202 & 82,718 & $\$ 7,364.37$ & 169.0 & $\$ 0.19$ & $\$ 0.11$ & $\$ 0.08$ \\
\hline 2203 & 84,575 & $\$ 12,465.90$ & 153.9 & $\$ 0.24$ & $\$ 0.12$ & $\$ 0.12$ \\
\hline 2204 & 73,490 & $\$ 8,340.69$ & 141.3 & $\$ 0.21$ & $\$ 0.10$ & $\$ 0.11$ \\
\hline 2205 & 82,498 & $\$ 8,360.75$ & 175.7 & $\$ 0.21$ & $\$ 0.11$ & $\$ 0.10$ \\
\hline 2206 & 84,474 & $\$ 7,286.81$ & 139.2 & $\$ 0.17$ & $\$ 0.13$ & $\$ 0.04$ \\
\hline 2207 & 87,766 & $\$ 9,996.05$ & 178.9 & $\$ 0.22$ & $\$ 0.12$ & $\$ 0.09$ \\
\hline Average CNG & 82,050 & $\$ 9,514.72$ & 165 & $\$ 0.22$ & $\$ 0.11$ & $\$ 0.10$ \\
\hline
\end{tabular}

The monthly scheduled and unscheduled maintenance cost per mile for the BEBs and CNG buses are shown as stacked columns in Figure 17. Scheduled maintenance for the BEBs was fairly consistent over the data period. The CNG buses typically have higher scheduled maintenance costs per mile than the BEBs and lower unscheduled costs per mile.

The average monthly odometer reading for each fleet is included in the figure. In April 2016, six of the CNG buses reached the mileage target for a major PMI, resulting in a spike for both scheduled and unscheduled maintenance costs for that month. Also during that month, Foothill Transit conducted tune-ups on five of the CNG buses.

The higher unscheduled maintenance costs for the BEBs in October and November 2016 were primarily due to tire replacements, troubleshooting for a low voltage electrical issue, and towing charges. The cost for tire damage, which is not related to the electric drive technology, accounted for $\$ 0.07 / \mathrm{mi}$ of the overall cost of the BEBs. 


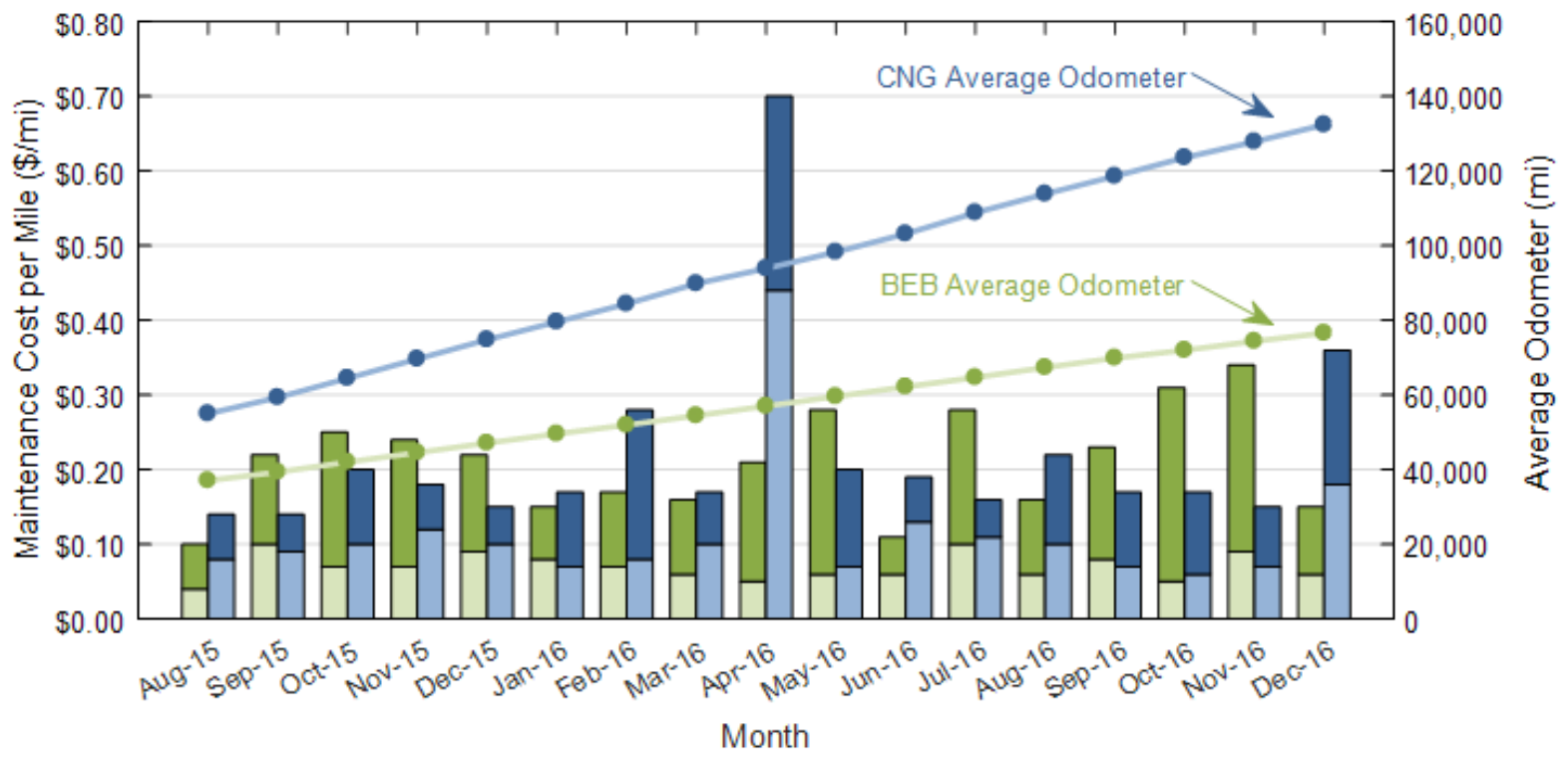

$\square$ BEB Scheduled $\square$ BEB Unscheduled $\square$ CNG Scheduled $\square$ CNG Unscheduled

Figure 17. Monthly scheduled and unscheduled maintenance costs per mile for the BEBs

\section{Work Order Maintenance Costs Categorized by System}

Table 11 shows maintenance costs by vehicle system and bus study group (without warranty costs). The vehicle systems shown in the table are as follows:

- Cab, body, and accessories: Includes body, glass, cab and sheet metal, seats and doors, and accessory repairs such as hubodometers and radios

- Propulsion-related systems: Repairs for exhaust, fuel, engine, electric motors, battery modules, propulsion control, non-lighting electrical (charging, cranking, and ignition), air intake, cooling, and transmission

- PMI: Labor for inspections during preventive maintenance

- Brakes: Includes brake pads, disks, calipers, anti-lock braking system, and brake chambers

- Frame, steering, and suspension

- HVAC

- Lighting

- Air system, general

- Axles, wheels, and drive shaft

- Tires

- Towing charges. 
Table 11. Work Order Maintenance Cost per Mile by System (Evaluation Period)

\begin{tabular}{|l|c|c|c|c|}
\hline \multirow{2}{*}{ System } & \multicolumn{2}{|c|}{ BEB } & \multicolumn{2}{c|}{ CNG } \\
\cline { 2 - 5 } & $\begin{array}{c}\text { Cost } \\
\text { per } \\
\text { Mile } \\
(\$)\end{array}$ & $\begin{array}{c}\text { Percent } \\
\text { of Total } \\
(\%)\end{array}$ & $\begin{array}{c}\text { Cost } \\
\text { per } \\
\text { Mile } \\
(\$)\end{array}$ & $\begin{array}{c}\text { Percent } \\
\text { of Total } \\
(\%)\end{array}$ \\
\hline Propulsion-related & 0.02 & 10 & 0.07 & 32 \\
\hline Cab, body, and accessories & 0.03 & 17 & 0.04 & 21 \\
\hline PMI & 0.07 & 33 & 0.05 & 24 \\
\hline Brakes & 0.00 & 0 & 0.00 & 2 \\
\hline Frame, steering, and suspension & 0.00 & 0 & 0.00 & 0 \\
\hline HVAC & 0.00 & 1 & 0.01 & 4 \\
\hline Lighting & 0.00 & 1 & 0.00 & 0 \\
\hline Air, general & 0.00 & 0 & 0.02 & 7 \\
\hline Axles, wheels, and drive shaft & 0.00 & 1 & 0.00 & 1 \\
\hline Tires & 0.07 & 34 & 0.02 & 9 \\
\hline Towing charges & 0.01 & 3 & 0.00 & 1 \\
\hline Total & $\mathbf{0 . 2 1}$ & 100 & $\mathbf{0 . 2 2}$ & 100 \\
\hline
\end{tabular}

The top three systems with the highest percentage of maintenance costs for the BEBs were (in order from highest to lowest) tires; PMI; and cab, body, and accessories. For the CNG buses the three systems with the highest percentage of maintenance costs were propulsion-related; PMI; and cab, body, and accessories. Figure 18 shows the monthly maintenance cost per mile by system for the BEBs. Figure 19 presents the same data for the CNG buses.

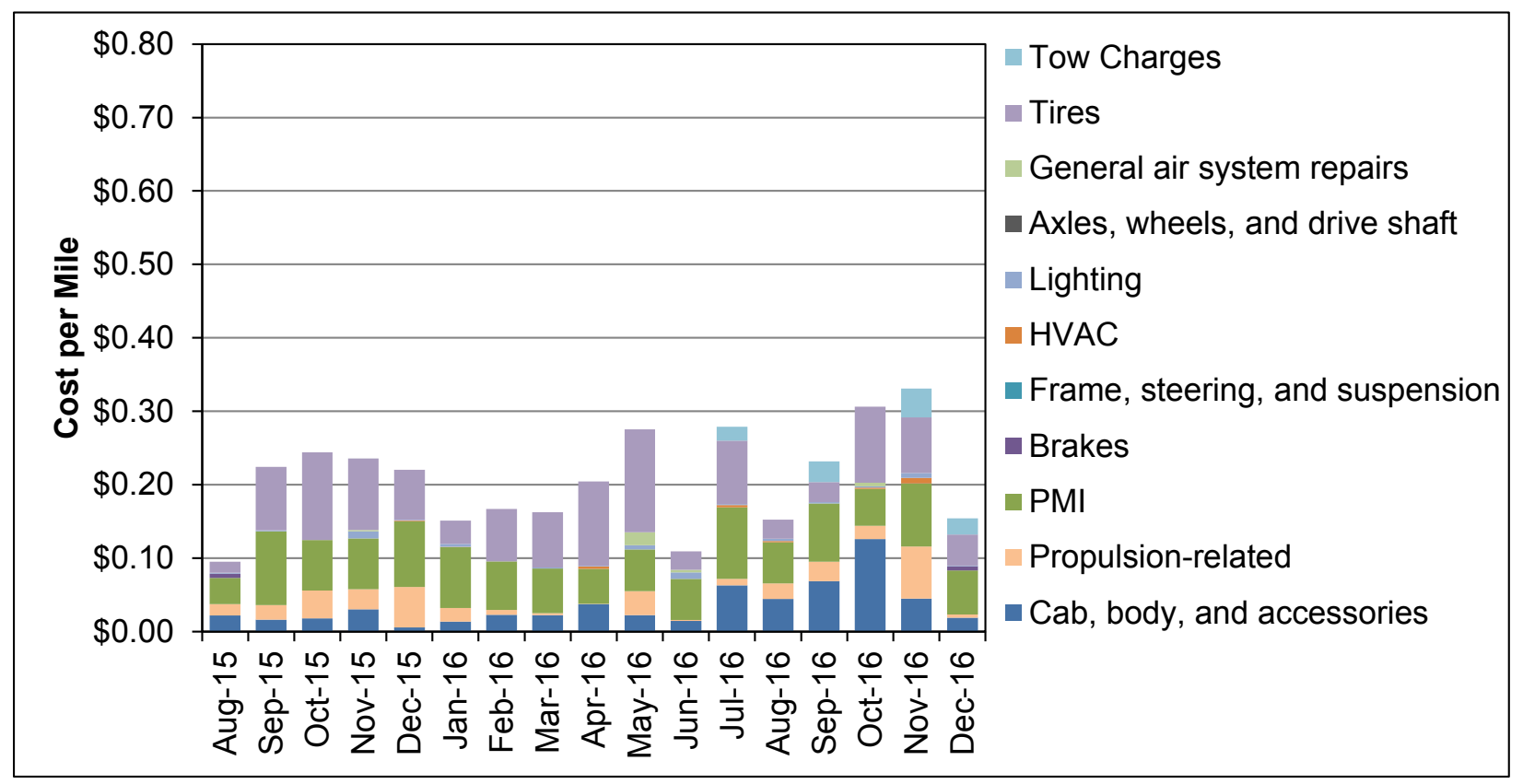

Figure 18. Monthly maintenance cost per mile by vehicle system for the BEBs 


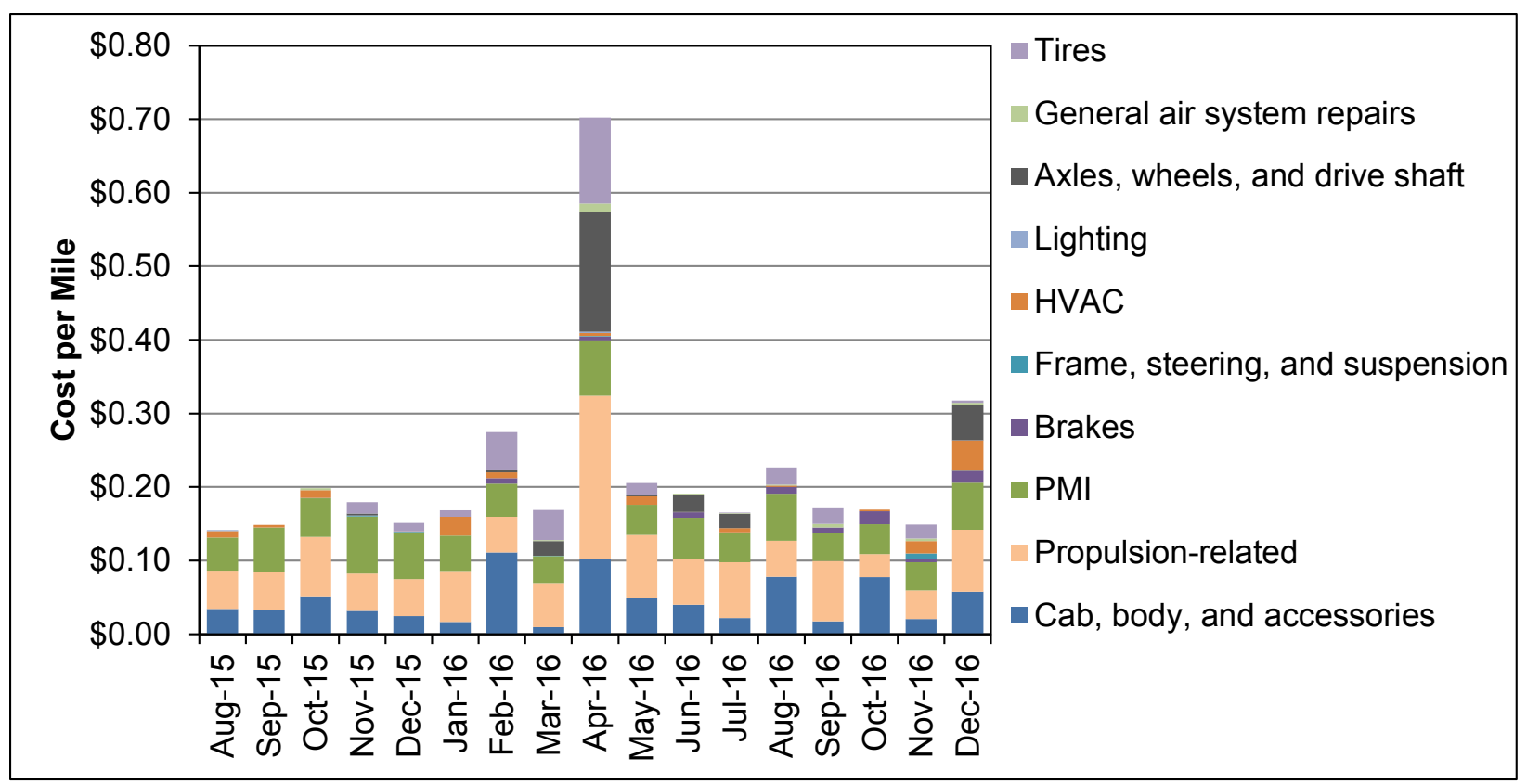

Figure 19. Monthly maintenance cost per mile by vehicle system for the CNG buses

\section{Propulsion-Related Work Order Maintenance Costs}

Propulsion-related vehicle systems include the exhaust, fuel, engine, battery modules, electric propulsion, air intake, cooling, non-lighting electrical, and transmission systems. These vehicle subsystems have been separated to highlight how maintenance costs for the propulsion system are affected by the change from conventional technology (CNG) to advanced technology (batteries).

Table 12 shows the propulsion-related system maintenance by category. During the data period, the propulsion-related maintenance costs for the BEBs were $68 \%$ lower than that of the CNG buses; however, the costs for both groups were low overall. Parts for scheduled maintenance, such as filters and fluids, are included in the specific system categories. For example, oil and oil filters are included in the power plant subsystem parts costs, while air filters are included in the air intake subsystem parts costs. 
Table 12. Propulsion-Related Work Order Maintenance Costs by System (Evaluation Period)

\begin{tabular}{|c|c|c|c|}
\hline Maintenance System & & BEB & CNG \\
\hline Total mileage & & 501,037 & 656,399 \\
\hline Average miles per bus & & 75,190 & 127,597 \\
\hline \multirow{4}{*}{$\begin{array}{l}\text { Total propulsion- } \\
\text { related systems } \\
\text { (roll-up of subsystems } \\
\text { below) }\end{array}$} & Parts cost $(\$)$ & $6,842.25$ & $34,141.06$ \\
\hline & Labor hours & 80.3 & 220.1 \\
\hline & Total cost $(\$)$ & $10,855.75$ & $45,146.06$ \\
\hline & Total cost (\$) per mile & 0.02 & 0.07 \\
\hline \multirow{4}{*}{ Exhaust system repairs } & Parts cost $(\$)$ & 0.00 & 157.20 \\
\hline & Labor hours & 0.0 & 1.5 \\
\hline & Total cost $(\$)$ & 0.00 & 232.20 \\
\hline & Total cost (\$) per mile & 0.00 & 0.00 \\
\hline \multirow{4}{*}{ Fuel system repairs } & Parts cost $(\$)$ & 0.00 & 487.89 \\
\hline & Labor hours & 0.0 & 18.7 \\
\hline & Total cost $(\$)$ & 0.00 & $1,422.89$ \\
\hline & Total cost (\$) per mile & 0.00 & 0.00 \\
\hline \multirow{4}{*}{$\begin{array}{l}\text { Power plant system } \\
\text { repairs (battery system } \\
\text { or CNG engine) }\end{array}$} & Parts cost $(\$)$ & 0.00 & $16,344.60$ \\
\hline & Labor hours & 1.5 & 63.8 \\
\hline & Total cost $(\$)$ & 75.00 & $19,534.60$ \\
\hline & Total cost (\$) per mile & 0.00 & 0.03 \\
\hline \multirow{4}{*}{$\begin{array}{l}\text { Electric motor and } \\
\text { propulsion system } \\
\text { repairs }\end{array}$} & Parts cost $(\$)$ & 0.00 & 0.00 \\
\hline & Labor hours & 21.4 & 0.0 \\
\hline & Total cost $(\$)$ & $1,070.00$ & 0.00 \\
\hline & Total cost (\$) per mile & 0.00 & 0.00 \\
\hline \multirow{4}{*}{$\begin{array}{l}\text { Non-lighting electrical } \\
\text { system repairs (general } \\
\text { electrical, charging, } \\
\text { cranking, ignition) }\end{array}$} & Parts cost $(\$)$ & $6,818.43$ & $4,765.93$ \\
\hline & Labor hours & 50.3 & 50.6 \\
\hline & Total cost $(\$)$ & $9,331.93$ & $7,295.93$ \\
\hline & Total cost (\$) per mile & 0.02 & 0.01 \\
\hline \multirow{4}{*}{$\begin{array}{l}\text { Air intake system } \\
\text { repairs }\end{array}$} & Parts cost $(\$)$ & 0.00 & $7,817.69$ \\
\hline & Labor hours & 3.9 & 0.0 \\
\hline & Total cost $(\$)$ & 195.00 & $7,817.69$ \\
\hline & Total cost (\$) per mile & 0.00 & 0.01 \\
\hline \multirow{4}{*}{ Cooling system repairs } & Parts cost $(\$)$ & 23.82 & $4,348.08$ \\
\hline & Labor hours & 2.5 & 73.8 \\
\hline & Total cost $(\$)$ & 148.82 & $8,038.08$ \\
\hline & Total cost (\$) per mile & 0.00 & 0.01 \\
\hline \multirow{4}{*}{$\begin{array}{l}\text { Transmission system } \\
\text { repairs }\end{array}$} & Parts cost $(\$)$ & 0.00 & 219.67 \\
\hline & Labor hours & 0.7 & 11.7 \\
\hline & Total cost $(\$)$ & 35.00 & 804.67 \\
\hline & Total cost (\$) per mile & 0.00 & 0.00 \\
\hline \multirow{4}{*}{$\begin{array}{l}\text { Hydraulic system } \\
\text { repairs }\end{array}$} & Parts cost $(\$)$ & 0.00 & 0.00 \\
\hline & Labor hours & 0.0 & 0.0 \\
\hline & Total cost $(\$)$ & 0.00 & 0.00 \\
\hline & Total cost (\$) per mile & 0.00 & 0.00 \\
\hline
\end{tabular}




\section{Potential PMI Cost Savings for BEBs}

Over time, Foothill Transit expects to save on PMI costs for BEBs compared to conventional buses. Proterra has established a PMI schedule for the BEBs based on mileage at intervals similar to that of conventional buses. Safety inspections and preventive maintenance for the busrelated systems on the BEBs are the same as that of conventional buses. The primary differences are related to the advanced components for the propulsion system. The PMI schedule for the BEBs has recommended intervals of 6,000 and 48,000 miles, while the PMI schedule for the CNG buses has recommended intervals of 6,$000 ; 12,000 ; 18,000 ; 24,000 ; 30,000$; and 36,000 miles.

The majority of time and materials costs for maintaining the CNG buses involve fluid and filter change outs. During PMIs for conventional buses, maintenance staff typically change out the oil, oil filter, fuel filter, air filter, and coolant filter. Fluid changes for the BEBs include motor coolant at 80,000 miles and transmission fluid at 100,000 miles. In addition to materials and labor cost savings for the BEBs compared to conventional buses, Foothill Transit reports that there are other potential savings for BEB operation. Operating conventional buses often requires many other costs that can be difficult to quantify, such as:

- Storage, handling, and proper disposal of used oil and other fluids

- Storage and disposal of used containers and oily rags

- Paperwork required for hazardous waste disposal

- Supplies and labor for cleaning the shop.

\section{Summary of Achievements and Challenges}

This section focuses on the achievements and challenges for Foothill Transit and its partners in implementing BEBs into the fleet. As with all new technology development, lessons learned during this project could aid other agencies considering BEB technology. There have been many achievements for the demonstration, including the following:

- The current fleet of twelve 35-ft BEBs continues to operate well, accumulating more than 902,000 miles (through December 2016). Foothill Transit operated its fleet of three firstgeneration Proterra BEBs from 2010 through 2013, accumulating more than 190,000 miles. In 2016, the agency received two 40-foot, fast charge buses. Foothill Transit's combined fleet of 17 Proterra BEBs has operated more than 1,134,000 miles.

- Bus MBRC for the entire evaluation period is more than 6,000 , surpassing the ultimate target of 4,000. Propulsion-related MBRC is more than 16,000 .

- The on-route fast chargers operated reliably with minimal issues, none of which resulted in downtime for the buses. Since installation of the chargers, Foothill Transit's combined BEB fleet (17 buses) has been charged 119,150 times. Availability of the two charging heads was $98 \%$ and $99 \%$.

- Proterra reports that the high voltage batteries are showing little to no signs of capacity degradation to date, and current estimates show they may last for up to 12 years. 
- Foothill Transit generates LCFS credits by operating the BEBs. Over the study period (Q3 2015-Q4 2016), Foothill Transit earned approximately \$126,000 in LCFS credits. The agency uses the funds as an additional revenue source to be applied wherever needed.

Advanced technology demonstrations typically experience challenges and issues that need to be resolved. The remainder of this section summarizes the primary issues that affected the demonstration as a whole.

Local monitor unit (LMU) failures-The LMU is part of the battery management system (BMS) for the BEBs. During the data period, a resistor within the LMU on three buses failed. Proterra has investigated the failures and believes they are due to stressing the board during previous electrical connection rework. As Proterra replaces the overstressed boards, the rate of failure has decreased. This failure is not related to the high-voltage batteries themselves. Proterra expects the part to last the life of the bus.

Tire damage - While not related to the advanced technology, tire damage continues to account for a significant portion of the maintenance costs for the BEBs at Foothill Transit. Since the buses went into service, Foothill Transit has replaced 100 tires at a parts cost of more than $\$ 37,800$ and 99.3 labor hours. Average cost per bus is $\$ 3,154$ and 8.3 labor hours. The CNG buses also had significant tire costs during the data period. The agency replaced 53 tires at a cost of more than $\$ 10,700$ and 68 labor hours. The per-bus average cost for the eight-bus CNG fleet is $\$ 1,346$ and 8.5 labor hours. Foothill Transit reports that this is likely due to the differing use between the BEBs and CNG buses. The local routes tend to have more road damage, such as potholes and broken curbs. The agency expects that the $\mathrm{CNG}$ buses would experience similar tire damage as the BEBs if they were only operated on the local routes.

Transmission issues - Several BEBs experienced transmission problems during the data period. Proterra has sent one of the failed transmissions to the supplier to determine the cause. A transmission replacement typically takes less than a day. One bus was out of service for an extended time because the new transmission was damaged during the installation and the agency had to wait for a new one to be shipped.

\section{Lessons Learned}

Foothill Transit and Proterra report that the project continues to go well. The partners highlighted the following key lessons learned since the beginning of the project:

- Short-range, on-route-charged buses are inflexible and cannot be deployed at other service routes that do not connect to an on-route charging location.

- Review potential routes and consider the ones that best fit how fast-charge BEBs operate based on driving range, duty cycle, and charging opportunities. An agency could benefit from conducting a route analysis and simulating how the BEBs would meet the power requirements.

- Adjust route schedules to accommodate BEB charging time; this is part of the transition from conventional technology buses to electric buses. An agency may need to add 
deadhead miles prior to the start of the route depending on the location of the in-route charging station and availability of an in-depot charger.

- Work with the local utility to address potential costs for demand and time-of-use charges.

- The higher use of air conditioning lowers the effective range in warmer months; Foothill Transit adjusts its summer schedule to account for more charging time.

- Charger availability is important for successful deployment. Foothill Transit installed two charger heads at its charging station to avoid downtime due to charger unavailability.

- Agencies operating BEBs can generate LCFS credits.

Foothill Transit reports that there is still a lot of learning as the agency ramps up to a larger BEB fleet. The agency has a goal of transitioning its fleet to $100 \%$ electric by 2030 . The team needs to develop plans in achieving this goal. As the technology improves to include longer range BEBs, Foothill Transit expects to manage more buses through overnight charging. To accomplish this, the agency is investigating options for charging a large number of buses in a limited space.

\section{What's Next}

Foothill Transit will continue operating the 12 BEBs on Line 291 and is evaluating other routes that might be well suited for electric buses. The agency has orders for Proterra's new Catalyst 40-foot BEB. The first two BEBs, which have been received and placed in service, are fastcharge buses. The remaining 13 BEBs will be the Catalyst E2 extended range model with a nominal range of 251 miles on a single charge.

The agency plans to operate the buses on Line $280-$ a 22 -mile round trip. Foothill Transit built a transit center (Azusa Intermodal Transit Center) which was completed in 2016 in partnership with the City of Azusa. The transit center serves Foothill Transit lines and the Metro Goldline station in Azusa. The underground infrastructure is installed for a charging station with two fastcharging heads, which will be built out in 2017 in conjunction with the BEB delivery schedule. Foothill Transit is looking at other potential routes for the 40 -foot buses as part of its fleet electrification initiative by 2030 . 


\section{Contacts}

\section{California Air Resources Board}

1001 I Street

P.O. Box 2815

Sacramento, CA 95812

Yachun Chow, Manager, Zero Emission Truck and Bus Section

Phone: 919-322-7450

Email: Yachun.Chow@arb.ca.gov

\section{NREL}

15013 Denver West Parkway

Golden, CO 80401

Leslie Eudy, Senior Project Leader, Technology Validation Team

Phone: 303-275-4412

Email: leslie.eudy@nrel.gov

\section{Foothill Transit}

$100 \mathrm{~S}$. Vincent Ave.

Suite 200

West Covina, CA 91790

Roland Cordero, Director of Maintenance and Vehicle Technology

Phone: 626-931-7246

Email: rcordero@,foothilltransit.org

\section{Proterra}

1 Whitley Court

Greenville, SC 29607

Mike Finnern, Customer Service Director

Phone: 864-214-0393

Email: MFinnern@Proterra.com 


\section{References and Related Reports}

All NREL hydrogen and fuel cell-related evaluation reports can be downloaded from the following website: www.nrel.gov/hydrogen/proj_fc bus_eval.html.

Eudy, L.; Prohaska, R.; Kelley, K.; Jeffers M. (2016). Foothill Transit Battery Electric Bus Demonstration Results. NREL/TP-5400-65274. Golden, CO: National Renewable Energy Laboratory. http://www.nrel.gov/docs/fy16osti/65274.pdf.

Eudy, L.; Post, M.; Jeffers M. (2016). Fuel Cell Buses in U.S. Transit Fleets: Current Status 2016. NREL/TP-5400-67097. Golden, CO: National Renewable Energy Laboratory. http://www.nrel.gov/docs/fy17osti/67097.pdf. 


\section{Appendix A: TRL Guideline Table}

Technology Readiness Levels for Advanced Technology Bus Commercialization ${ }^{a}$

\begin{tabular}{|c|c|c|c|}
\hline $\begin{array}{l}\text { Relative Level } \\
\text { of Technology } \\
\text { Development }\end{array}$ & $\begin{array}{l}\text { Technology } \\
\text { Readiness } \\
\text { Level }\end{array}$ & TRL Definition & Description \\
\hline Deployment & TRL 9 & $\begin{array}{l}\text { Actual system } \\
\text { operated over the full } \\
\text { range of expected } \\
\text { conditions }\end{array}$ & $\begin{array}{l}\text { The technology is in its final form. } \\
\text { Deployment, marketing, and support begin for } \\
\text { the first fully commercial products. }\end{array}$ \\
\hline \multirow{3}{*}{$\begin{array}{l}\text { Technology } \\
\text { Demonstration/ } \\
\text { Commissioning }\end{array}$} & TRL 8 & $\begin{array}{l}\text { Actual system } \\
\text { completed and } \\
\text { qualified through test } \\
\text { and demonstration }\end{array}$ & $\begin{array}{l}\text { The last step in true system development. } \\
\text { Demonstration of a limited production of } 50 \text { to } \\
100 \text { buses at a small number of locations. } \\
\text { Beginning the transition of all maintenance to } \\
\text { transit staff. }\end{array}$ \\
\hline & TRL 7 & $\begin{array}{l}\text { Full-scale validation in } \\
\text { relevant environment }\end{array}$ & $\begin{array}{l}\text { A major step up from TRL } 6 \text { by adding larger } \\
\text { numbers of buses and increasing the hours of } \\
\text { service. Full-scale demonstration and } \\
\text { reliability testing of } 5 \text { to } 10 \text { buses at several } \\
\text { locations. Manufacturers begin to train larger } \\
\text { numbers of transit staff in operation and } \\
\text { maintenance. }\end{array}$ \\
\hline & TRL 6 & $\begin{array}{l}\text { Engineering/pilot-scale } \\
\text { validation in relevant } \\
\text { environment }\end{array}$ & $\begin{array}{l}\text { First tests of prototype buses in actual transit } \\
\text { service. Field testing and design shakedown } \\
\text { of one to two prototypes. Manufacturers assist } \\
\text { in operation and typically handle all } \\
\text { maintenance. Begin to introduce transit staff to } \\
\text { technology. }\end{array}$ \\
\hline \multirow{2}{*}{$\begin{array}{l}\text { Technology } \\
\text { Development }\end{array}$} & TRL 5 & $\begin{array}{l}\text { Laboratory scale, } \\
\text { similar system } \\
\text { validation in relevant } \\
\quad \text { environment }\end{array}$ & $\begin{array}{l}\text { Integrated system is tested in a laboratory } \\
\text { under simulated conditions based on early } \\
\text { modeling. System is integrated into an early } \\
\text { prototype or mule platform for some on-road } \\
\text { testing. }\end{array}$ \\
\hline & TRL 4 & $\begin{array}{l}\text { Component and } \\
\text { system validation in } \\
\text { laboratory environment }\end{array}$ & $\begin{array}{l}\text { Basic technological components are } \\
\text { integrated into the system and begin } \\
\text { laboratory testing and modeling of potential } \\
\text { duty cycles. }\end{array}$ \\
\hline \multirow[t]{2}{*}{$\begin{array}{l}\text { Research to } \\
\text { Prove } \\
\text { Feasibility }\end{array}$} & TRL 3 & $\begin{array}{c}\text { Analytical and } \\
\text { experimental critical } \\
\text { function and/or proof of } \\
\text { concept }\end{array}$ & $\begin{array}{l}\text { Active research into components and system } \\
\text { integration needs. Investigate what } \\
\text { requirements might be met with existing } \\
\text { commercial components. }\end{array}$ \\
\hline & & Technology concept & Research technology needed to meet market \\
\hline \multirow{2}{*}{$\begin{array}{l}\text { Basic } \\
\text { Technology } \\
\text { Research }\end{array}$} & TRL 2 & $\begin{array}{l}\text { and/or application } \\
\text { formulated }\end{array}$ & $\begin{array}{l}\text { requirements. Define strategy for moving } \\
\text { through development stages. }\end{array}$ \\
\hline & TRL 1 & $\begin{array}{c}\text { Basic principles } \\
\text { observed and reported }\end{array}$ & $\begin{array}{l}\text { Scientific research and early development of } \\
\text { concepts. }\end{array}$ \\
\hline
\end{tabular}

${ }^{a}$ This guideline considers the bus as a whole and does not account for differing TRLs for separate components or subsystems. Some subsystems may include off-the-shelf components that are considered commercial, while other subsystems may feature newly designed components at an earlier TRL. 


\section{Appendix B: Foothill Transit Fleet Summary Statistics}

\begin{tabular}{|c|c|c|c|c|}
\hline & $\begin{array}{l}\text { BEB } \\
\text { All Data }\end{array}$ & $\begin{array}{l}\text { BEB } \\
\text { Report } \\
\text { Period }\end{array}$ & $\begin{array}{l}\text { CNG } \\
\text { All Data }\end{array}$ & $\begin{array}{l}\text { CNG } \\
\text { Report } \\
\text { Period }\end{array}$ \\
\hline Number of vehicles & 12 & 12 & 8 & 8 \\
\hline Period used for fuel and energy op analysis & $4 / 14-12 / 16$ & $8 / 15-12 / 16$ & $10 / 14-12 / 16$ & $8 / 15-12 / 16$ \\
\hline Total number of months in period & 33 & 17 & 27 & 17 \\
\hline Fuel and energy analysis base fleet mileage & 902,281 & 501,037 & 929,451 & 634,918 \\
\hline Period used for maintenance op analysis & $1 / 15-12 / 16$ & $8 / 15-12 / 16$ & $10 / 14-12 / 16$ & $8 / 15-12 / 16$ \\
\hline Total number of months in period & 24 & 17 & 27 & 17 \\
\hline Maintenance analysis base fleet mileage & 706,078 & 501,037 & $1,020,772$ & 656,399 \\
\hline Average monthly mileage per vehicle & 2,400 & 2,456 & 4,726 & 4,826 \\
\hline Availability (\%) & 90 & 90 & 93 & 93 \\
\hline $\begin{array}{l}\text { Fleet energy usage in kWh (BEB) or gge } \\
\text { (CNG) }\end{array}$ & $1,951,862$ & $1,087,276$ & 236,345 & 163,368 \\
\hline Roadcalls & 146 & 104 & 35 & 27 \\
\hline Total MBRC & 6,180 & 4,818 & 29,165 & 24,311 \\
\hline Propulsion-related roadcalls & 55 & 40 & 18 & 14 \\
\hline Propulsion-related MBRC & 16,405 & 12,526 & 56,710 & 46,886 \\
\hline Average speed, including stops (mph) & 10.6 & 10.6 & 17.6 & 17.6 \\
\hline Fleet kWh/mile (BEB) or miles/gge (CNG) & 2.16 & 2.17 & 3.93 & 3.89 \\
\hline Fleet average fuel economy (mpdge) & 17.41 & 17.35 & 4.39 & 4.34 \\
\hline $\begin{array}{l}\text { CNG fleet average fuel economy (mpdge) at } \\
\text { similar average driving speed as BEB fleet }\end{array}$ & & & 2.09 & 2.09 \\
\hline Energy cost per kWh & $\$ 0.17$ & $\$ 0.17$ & & \\
\hline CNG cost per gge & & & $\$ 0.95$ & $\$ 0.96$ \\
\hline $\begin{array}{l}\text { Energy/fuel cost per mile (based on purchased } \\
\text { energy) }\end{array}$ & $\$ 0.43$ & $\$ 0.41$ & $\$ 0.24$ & $\$ 0.25$ \\
\hline $\begin{array}{l}\text { CNG fuel cost per mile at similar average } \\
\text { driving speed as BEB fleet }\end{array}$ & & & $\$ 0.45$ & $\$ 0.46$ \\
\hline Total scheduled repair cost per mile & $\$ 0.07$ & $\$ 0.07$ & $\$ 0.12$ & $\$ 0.11$ \\
\hline Total unscheduled repair cost per mile & $\$ 0.12$ & $\$ 0.14$ & $\$ 0.08$ & $\$ 0.10$ \\
\hline Total maintenance cost per mile & $\$ 0.19$ & $\$ 0.21$ & $\$ 0.20$ & $\$ 0.22$ \\
\hline Total operating cost per mile (as operated) & $\$ 0.62$ & $\$ 0.62$ & $\$ 0.45$ & $\$ 0.46$ \\
\hline $\begin{array}{l}\text { Total operating cost per mile at similar } \\
\text { average driving speed, excluding tire costs }\end{array}$ & $\$ 0.56$ & $\$ 0.55$ & $\$ 0.65$ & $\$ 0.66$ \\
\hline
\end{tabular}




\section{Maintenance Costs}

\begin{tabular}{|l|r|r|r|r|}
\hline & \multicolumn{1}{|c|}{$\begin{array}{c}\text { BEB } \\
\text { All Data }\end{array}$} & $\begin{array}{c}\text { BEB } \\
\text { Report } \\
\text { Period }\end{array}$ & \multicolumn{1}{c|}{$\begin{array}{c}\text { CNG } \\
\text { All Data }\end{array}$} & $\begin{array}{r}\text { CNG } \\
\text { Report } \\
\text { Period }\end{array}$ \\
\hline Fleet mileage & 706,078 & 501,037 & $1,020,772$ & 656,399 \\
\hline Total parts cost $(\$)$ & $54,932.79$ & $45,588.07$ & $108,879.49$ & $76,117.76$ \\
\hline Total labor hours & $1,647.9$ & $1,165.5$ & $1,997.2$ & $1,317.8$ \\
\hline Average labor cost (@ \$50.00 per hour) (\$) & $82,397.00$ & $58,277.00$ & $99,860.00$ & $65,887.50$ \\
\hline Total maintenance cost (\$) & $137,329.79$ & $103,865.07$ & $208,739.49$ & $142,005.26$ \\
\hline Total maintenance cost per bus (\$) & $11,444.15$ & $8,655.42$ & $26,092.44$ & $17,750.66$ \\
\hline Total maintenance cost per mile (\$) & $\mathbf{0 . 1 9}$ & $\mathbf{0 . 2 1}$ & $\mathbf{0 . 2 0}$ & $\mathbf{0 . 2 2}$ \\
\hline $\begin{array}{l}\text { Total maintenance cost per mile, excluding } \\
\text { tire costs }(\$)\end{array}$ & $\mathbf{0 . 1 3}$ & $\mathbf{0 . 1 4}$ & $\mathbf{0 . 1 9}$ & $\mathbf{0 . 2 0}$ \\
\hline
\end{tabular}




\begin{tabular}{|c|c|c|c|c|}
\hline & $\begin{array}{c}\text { BEB } \\
\text { All Data }\end{array}$ & $\begin{array}{c}\text { BEB } \\
\text { Report } \\
\text { Period }\end{array}$ & $\begin{array}{c}\text { CNG } \\
\text { All Data }\end{array}$ & $\begin{array}{c}\text { CNG } \\
\text { Report } \\
\text { Period }\end{array}$ \\
\hline Fleet mileage & 706,078 & 501,037 & $1,020,772$ & 656,399 \\
\hline \multicolumn{5}{|c|}{ Total Engine/Fuel-Related Systems (ATA VMRS 27, 30, 31, 32, 33, 41, 42, 43, 44, 45, 46, 65) } \\
\hline Parts cost $(\$)$ & $9,263.26$ & $6,842.25$ & $57,194.31$ & $34,141.06$ \\
\hline Labor hours & 116.27 & 80.27 & 311.35 & 220.10 \\
\hline Average labor cost $(\$)$ & $5,813.50$ & $4,013.50$ & $15,567.50$ & $11,005.00$ \\
\hline Total cost (for system) $(\$)$ & $15,076.76$ & $10,855.75$ & $72,761.81$ & $45,146.06$ \\
\hline Total cost (for system) per bus $(\$)$ & 456.87 & 328.96 & $2,204.90$ & $1,368.06$ \\
\hline Total cost (for system) per mile $(\$)$ & 0.02 & 0.02 & 0.07 & 0.07 \\
\hline \multicolumn{5}{|c|}{ Exhaust System Repairs (ATA VMRS 43) } \\
\hline Parts cost $(\$)$ & 0.00 & 0.00 & 157.20 & 157.20 \\
\hline Labor hours & 0.0 & 0.0 & 1.5 & 1.5 \\
\hline Average labor cost $(\$)$ & 0.00 & 0.00 & 75.00 & 75.00 \\
\hline Total cost (for system) (\$) & 0.00 & 0.00 & 232.20 & 232.20 \\
\hline Total cost (for system) per bus $(\$)$ & 0.00 & 0.00 & 7.04 & 7.04 \\
\hline Total cost (for system) per mile (\$) & 0.00 & 0.00 & 0.00 & 0.00 \\
\hline \multicolumn{5}{|l|}{ Fuel System Repairs (ATA VMRS 44) } \\
\hline Parts cost $(\$)$ & 0.00 & 0.00 & 552.57 & 487.89 \\
\hline Labor hours & 0.0 & 0.0 & 25.2 & 18.7 \\
\hline Average labor cost $(\$)$ & 0.00 & 0.00 & $1,260.00$ & 935.00 \\
\hline Total cost (for system) $(\$)$ & 0.00 & 0.00 & $1,812.57$ & $1,422.89$ \\
\hline Total cost (for system) per bus $(\$)$ & 0.00 & 0.00 & 54.93 & 43.12 \\
\hline Total cost (for system) per mile (\$) & 0.00 & 0.00 & 0.00 & 0.00 \\
\hline \multicolumn{5}{|c|}{ Power Plant (Engine or ESS) Repairs (ATA VMRS 45) } \\
\hline Parts cost $(\$)$ & 0.00 & 0.00 & $31,934.86$ & $16,344.60$ \\
\hline Labor hours & 11.0 & 1.5 & 89.3 & 63.8 \\
\hline Average labor cost $(\$)$ & 550.00 & 75.00 & $4,465.00$ & $3,190.00$ \\
\hline Total cost (for system) $(\$)$ & 550.00 & 75.00 & $36,399.86$ & $19,534.60$ \\
\hline Total cost (for system) per bus $(\$)$ & 16.67 & 2.27 & $1,103.03$ & 591.96 \\
\hline Total cost (for system) per mile (\$) & 0.00 & 0.00 & 0.04 & 0.03 \\
\hline \multicolumn{5}{|c|}{ Electric Propulsion Repairs (ATA VMRS 46) } \\
\hline Parts cost $(\$)$ & 0.00 & 0.00 & 0.00 & 0.00 \\
\hline Labor hours & 22.9 & 21.4 & 0.0 & 0.0 \\
\hline Average labor cost $(\$)$ & $1,145.00$ & $1,070.00$ & 0.00 & 0.00 \\
\hline Total cost (for system) $(\$)$ & $1,145.00$ & $1,070.00$ & 0.00 & 0.00 \\
\hline Total cost (for system) per bus $(\$)$ & 34.70 & 32.42 & 0.00 & 0.00 \\
\hline Total cost (for system) per mile (\$) & 0.00 & 0.00 & 0.00 & 0.00 \\
\hline
\end{tabular}


Breakdown of Maintenance Costs by Vehicle System (continued)

\begin{tabular}{|c|c|c|c|c|}
\hline & $\begin{array}{l}\text { BEB } \\
\text { All Data }\end{array}$ & $\begin{array}{l}\text { BEB } \\
\text { Report } \\
\text { Period }\end{array}$ & $\begin{array}{l}\text { CNG } \\
\text { All Data }\end{array}$ & $\begin{array}{l}\text { CNG } \\
\text { Report } \\
\text { Period }\end{array}$ \\
\hline \multicolumn{5}{|c|}{$\begin{array}{l}\text { Electrical System Repairs (ATA VMRS 30-Electrical General, 31-Charging, 32-Cranking, 33- } \\
\text { Ignition) }\end{array}$} \\
\hline Parts cost $(\$)$ & $9,239.44$ & $6,818.43$ & $5,924.77$ & $4,765.93$ \\
\hline Labor hours & 74.8 & 50.3 & 79.6 & 50.6 \\
\hline Average labor cost $(\$)$ & $3,738.50$ & $2,513.50$ & $3,980.00$ & $2,530.00$ \\
\hline Total cost (for system) (\$) & $12,977.94$ & $9,331.93$ & $9,904.77$ & $7,295.93$ \\
\hline Total cost (for system) per bus (\$) & 393.27 & 282.79 & 300.14 & 221.09 \\
\hline Total cost (for system) per mile $(\$)$ & 0.02 & 0.02 & 0.01 & 0.01 \\
\hline \multicolumn{5}{|c|}{ Air Intake System Repairs (ATA VMRS 41) } \\
\hline Parts cost $(\$)$ & 0.00 & 0.00 & $12,057.79$ & $7,817.69$ \\
\hline Labor hours & 3.9 & 3.9 & 0.8 & 0.0 \\
\hline Average labor cost $(\$)$ & 195.00 & 195.00 & 37.50 & 0.00 \\
\hline Total cost (for system) (\$) & 195.00 & 195.00 & $12,095.29$ & $7,817.69$ \\
\hline Total cost (for system) per bus $(\$)$ & 5.91 & 5.91 & 366.52 & 236.90 \\
\hline Total cost (for system) per mile $(\$)$ & 0.00 & 0.00 & 0.01 & 0.01 \\
\hline \multicolumn{5}{|c|}{ Cooling System Repairs (ATA VMRS 42) } \\
\hline Parts cost $(\$)$ & 23.82 & 23.82 & $6,158.30$ & $4,348.08$ \\
\hline Labor hours & 2.5 & 2.5 & 98.3 & 73.8 \\
\hline Average labor cost $(\$)$ & 125.00 & 125.00 & $4,915.00$ & $3,690.00$ \\
\hline Total cost (for system) $(\$)$ & 148.82 & 148.82 & $11,073.30$ & $8,038.08$ \\
\hline Total cost (for system) per bus $(\$)$ & 4.51 & 4.51 & 335.55 & 243.58 \\
\hline Total cost (for system) per mile $(\$)$ & 0.00 & 0.00 & 0.01 & 0.01 \\
\hline \multicolumn{5}{|c|}{ Hydraulic System Repairs (ATA VMRS 65) } \\
\hline Parts cost (\$) & 0.00 & 0.00 & 0.00 & 0.00 \\
\hline Labor hours & 0.0 & 0.0 & 0.0 & 0.0 \\
\hline Average labor cost $(\$)$ & 0.00 & 0.00 & 0.00 & 0.00 \\
\hline Total cost (for system) $(\$)$ & 0.00 & 0.00 & 0.00 & 0.00 \\
\hline Total cost (for system) per bus ( $\$$ ) & 0.00 & 0.00 & 0.00 & 0.00 \\
\hline Total cost (for system) per mile $(\$)$ & 0.00 & 0.00 & 0.00 & 0.00 \\
\hline \multicolumn{5}{|c|}{ General Air System Repairs (ATA VMRS 10) } \\
\hline Parts cost $(\$)$ & 54.04 & 54.04 & $1,269.07$ & 713.20 \\
\hline Labor hours & 25.8 & 15.5 & 15.9 & 7.9 \\
\hline Average labor cost $(\$)$ & $1,287.50$ & 775.00 & 795.00 & 395.00 \\
\hline Total cost (for system) $(\$)$ & $1,341.54$ & 829.04 & $2,064.07$ & $1,108.20$ \\
\hline Total cost (for system) per bus $(\$)$ & 40.65 & 25.12 & 62.55 & 33.58 \\
\hline Total cost (for system) per mile $(\$)$ & 0.00 & 0.00 & 0.00 & 0.00 \\
\hline
\end{tabular}


Breakdown of Maintenance Costs by Vehicle System (continued)

\begin{tabular}{|c|c|c|c|c|}
\hline & $\begin{array}{l}\text { BEB } \\
\text { All Data }\end{array}$ & $\begin{array}{l}\text { BEB } \\
\text { Report } \\
\text { Period }\end{array}$ & $\begin{array}{l}\text { CNG } \\
\text { All Data }\end{array}$ & $\begin{array}{l}\text { CNG } \\
\text { Report } \\
\text { Period }\end{array}$ \\
\hline \multicolumn{5}{|l|}{ Brake System Repairs (ATA VMRS 13) } \\
\hline Parts cost $(\$)$ & 0.00 & 0.00 & $2,281.00$ & $2,281.00$ \\
\hline Labor hours & 6.7 & 6.7 & 11.2 & 11.2 \\
\hline Average labor cost $(\$)$ & 335.00 & 335.00 & 560.00 & 560.00 \\
\hline Total cost (for system) $(\$)$ & 335.00 & 335.00 & $2,841.00$ & $2,841.00$ \\
\hline Total cost (for system) per bus (\$) & 10.15 & 10.15 & 86.09 & 86.09 \\
\hline Total cost (for system) per mile (\$) & 0.00 & 0.00 & 0.00 & 0.00 \\
\hline \multicolumn{5}{|l|}{ Transmission Repairs (ATA VMRS 27) } \\
\hline Parts cost $(\$)$ & 0.00 & 0.00 & 408.82 & 219.67 \\
\hline Labor hours & 1.2 & 0.7 & 16.7 & 11.7 \\
\hline Average labor cost $(\$)$ & 60.00 & 35.00 & 835.00 & 585.00 \\
\hline Total cost (for system) $(\$)$ & 60.00 & 35.00 & $1,243.82$ & 804.67 \\
\hline Total cost (for system) per bus (\$) & 1.82 & 1.06 & 37.69 & 24.38 \\
\hline Total cost (for system) per mile (\$) & 0.00 & 0.00 & 0.00 & 0.00 \\
\hline \multicolumn{5}{|c|}{ Inspections Only - no parts replacements (101) } \\
\hline Parts cost $(\$)$ & 0.00 & 0.00 & 0.00 & 0.00 \\
\hline Labor hours & 979.4 & 684.2 & 1119.1 & 680.6 \\
\hline Average labor cost $(\$)$ & $48,970.00$ & $34,210.00$ & $55,955.00$ & $34,030.00$ \\
\hline Total cost (for system) (\$) & $48,970.00$ & $34,210.00$ & $55,955.00$ & $34,030.00$ \\
\hline Total cost (for system) per bus $(\$)$ & $1,483.94$ & $1,036.67$ & $1,695.61$ & $1,031.21$ \\
\hline Total cost (for system) per mile $(\$)$ & 0.07 & 0.07 & 0.05 & 0.05 \\
\hline \multicolumn{5}{|c|}{$\begin{array}{l}\text { Cab, Body, and Accessories Systems Repairs (ATA VMRS 02-Cab and Sheet Metal, 50- } \\
\text { Accessories, 71-Body) }\end{array}$} \\
\hline Parts cost (\$) & $3,749.39$ & $3,562.03$ & $15,590.95$ & $14,654.88$ \\
\hline Labor hours & 384.0 & 272.0 & 412.7 & 296.9 \\
\hline Average labor cost $(\$)$ & $19,198.50$ & $13,601.00$ & $20,635.00$ & $14,845.00$ \\
\hline Total cost (for system) $(\$)$ & $22,947.89$ & $17,163.03$ & $36,225.95$ & $29,499.88$ \\
\hline Total cost (for system) per bus $(\$)$ & 695.39 & 520.09 & $1,097.76$ & 893.94 \\
\hline Total cost (for system) per mile $(\$)$ & 0.03 & 0.03 & 0.04 & 0.04 \\
\hline \multicolumn{5}{|l|}{ HVAC System Repairs (ATA VMRS 01) } \\
\hline Parts cost $(\$)$ & 55.59 & 55.59 & $4,454.57$ & $3,935.89$ \\
\hline Labor hours & 10.0 & 9.5 & 41.0 & 29.6 \\
\hline Average labor cost $(\$)$ & 500.00 & 475.00 & $2,050.00$ & $1,480.00$ \\
\hline Total cost (for system) $(\$)$ & 555.59 & 530.59 & $6,504.57$ & $5,415.89$ \\
\hline Total cost (for system) per bus (\$) & 16.84 & 16.08 & 197.11 & 164.12 \\
\hline Total cost (for system) per mile $(\$)$ & 0.00 & 0.00 & 0.01 & 0.01 \\
\hline
\end{tabular}


Breakdown of Maintenance Costs by Vehicle System (continued)

\begin{tabular}{|c|c|c|c|c|}
\hline & $\begin{array}{c}\text { BEB } \\
\text { All Data }\end{array}$ & $\begin{array}{l}\text { BEB } \\
\text { Report } \\
\text { Period }\end{array}$ & $\begin{array}{l}\text { CNG } \\
\text { All Data }\end{array}$ & $\begin{array}{l}\text { CNG } \\
\text { Report } \\
\text { Period }\end{array}$ \\
\hline \multicolumn{5}{|c|}{ Lighting System Repairs (ATA VMRS 34) } \\
\hline Parts cost (\$) & 173.74 & 173.74 & 20.52 & 20.52 \\
\hline Labor hours & 26.6 & 25.6 & 2.0 & 2.0 \\
\hline Average labor cost $(\$)$ & $1,327.50$ & $1,277.50$ & 97.50 & 97.50 \\
\hline Total cost (for system) $(\$)$ & $1,501.24$ & $1,451.24$ & 118.02 & 118.02 \\
\hline Total cost (for system) per bus $(\$)$ & 45.49 & 43.98 & 3.58 & 3.58 \\
\hline Total cost (for system) per mile $(\$)$ & 0.00 & 0.00 & 0.00 & 0.00 \\
\hline \multicolumn{5}{|c|}{ Frame, Steering, and Suspension Repairs (ATA VMRS 14-Frame, 15-Steering, 16-Suspension) } \\
\hline Parts cost $(\$)$ & 0.00 & 0.00 & 387.02 & 352.30 \\
\hline Labor hours & 0.0 & 0.0 & 6.7 & 2.7 \\
\hline Average labor cost $(\$)$ & 0.00 & 0.00 & 335.00 & 135.00 \\
\hline Total cost (for system) $(\$)$ & 0.00 & 0.00 & 722.02 & 487.30 \\
\hline Total cost (for system) per bus (\$) & 0.00 & 0.00 & 21.88 & 14.77 \\
\hline Total cost (for system) per mile (\$) & 0.00 & 0.00 & 0.00 & 0.00 \\
\hline \multicolumn{5}{|c|}{$\begin{array}{l}\text { Axle, Wheel, and Drive Shaft Repairs (ATA VMRS 11-Front Axle, 18-Wheels, 22-Rear Axle, 24- } \\
\text { Drive Shaft) }\end{array}$} \\
\hline Parts cost $(\$)$ & 0.00 & 0.00 & $15,703.90$ & $9,600.96$ \\
\hline Labor hours & 0.0 & 0.0 & 8.0 & 6.0 \\
\hline Average labor cost $(\$)$ & 0.00 & 0.00 & 400.00 & 300.00 \\
\hline Total cost (for system) $(\$)$ & 0.00 & 0.00 & $16,103.90$ & $9,900.96$ \\
\hline Total cost (for system) per bus $(\$)$ & 0.00 & 0.00 & 488.00 & 300.03 \\
\hline Total cost (for system) per mile (\$) & 0.00 & 0.00 & 0.02 & 0.02 \\
\hline \multicolumn{5}{|l|}{ Tire Repairs (ATA VMRS 17) } \\
\hline Parts cost $(\$)$ & $38,501.77$ & $31,765.42$ & $10,775.15$ & $9,214.95$ \\
\hline Labor hours & 99.3 & 71.8 & 68.3 & 59.8 \\
\hline Average labor cost $(\$)$ & $4,965.00$ & $3,590.00$ & $3,415.00$ & $2,990.00$ \\
\hline Total cost (for system) $(\$)$ & $43,466.77$ & $35,355.42$ & $14,190.15$ & $12,204.95$ \\
\hline Total cost (for system) per bus (\$) & $1,317.17$ & $1,071.38$ & 430.00 & 369.85 \\
\hline Total cost (for system) per mile $(\$)$ & 0.06 & 0.07 & 0.01 & 0.02 \\
\hline \multicolumn{5}{|l|}{ Towing Charges } \\
\hline Parts cost $(\$)$ & $3,135.00$ & $3,135.00$ & 1203 & $1,203.00$ \\
\hline Labor hours & 0.00 & 0.00 & 1.0 & 1.0 \\
\hline Average labor cost $(\$)$ & 0.00 & 0.00 & 50.00 & 50.00 \\
\hline Total cost (for system) $(\$)$ & $3,135.00$ & $3,135.00$ & $1,253.00$ & $1,253.00$ \\
\hline Total cost (for system) per bus (\$) & 95.00 & 95.00 & 37.97 & 37.97 \\
\hline Total cost (for system) per mile $(\$)$ & 0.00 & 0.01 & 0.00 & 0.00 \\
\hline
\end{tabular}




\section{Notes}

1. To compare the charging energy to CNG fuel and diesel equivalent, the energy and CNG were converted into diesel energy equivalent gallons. Actual energy content will vary by location, but the general energy conversions are based on the following:

Lower heating value $(\mathrm{LHV})$ for diesel $=128,488 \mathrm{Btu} / \mathrm{gal}$ (Alternative Fuels Data Center, fuel properties database ${ }^{8}$ )

U.S. average energy content of electricity $=3,412$ Btu/kWh (Energy Information Administration)

Conversion factor for calculations $=37.7 \mathrm{kWh} / \mathrm{gal}$

CNG fuel is reported as gasoline gallon equivalent (gge). The gasoline LHV is $115,000 \mathrm{Btu} / \mathrm{gal}$.

Gasoline/Diesel $=115,000 \mathrm{Btu} / \mathrm{gallon} / 128,400 \mathrm{Btu} / \mathrm{gallon}=0.896 \mathrm{gge} / \mathrm{gal}$

2. The propulsion-related systems were chosen to include only those systems of the vehicles that could be affected directly by the selection of a fuel or advanced technology.

3. ATA VMRS coding is based on parts that were replaced. If there was no part replaced in a given repair, then the code was chosen by the system being worked on.

4. In general, inspections (with no part replacements) were included only in the overall totals (not by system). Category 101 was created to track labor costs for PMls.

5. ATA VMRS 02-Cab and Sheet Metal represents seats, doors, etc.; ATA VMRS 50-Accessories represents things like fire extinguishers, test kits, fareboxes, etc.; ATA VMRS 71-Body represents mostly windows and windshields.

6. Average labor cost is assumed to be $\$ 50$ per hour.

7. Warranty costs are not included.

\footnotetext{
${ }^{8}$ http://www.afdc.energy.gov/fuels/fuel_properties.php
} 


\section{Appendix C: Foothill Transit Fleet Summary Statistics-SI Units}

\begin{tabular}{|c|c|c|c|c|}
\hline & $\begin{array}{c}\text { BEB } \\
\text { All Data }\end{array}$ & $\begin{array}{l}\text { BEB Report } \\
\text { Period }\end{array}$ & $\begin{array}{c}\text { CNG } \\
\text { All Data }\end{array}$ & $\begin{array}{l}\text { CNG } \\
\text { Report } \\
\text { Period }\end{array}$ \\
\hline Number of vehicles & 12 & 12 & 8 & 8 \\
\hline Period used for fuel and energy op analysis & $4 / 14-12 / 16$ & $8 / 15-12 / 16$ & $10 / 14-12 / 16$ & $8 / 15-12 / 16$ \\
\hline Total number of months in period & 33 & 17 & 27 & 17 \\
\hline Fuel and energy analysis base fleet mileage & $1,452,041$ & 806,319 & $1,495,765$ & $1,021,774$ \\
\hline Period used for maintenance op analysis & $1 / 15-12 / 16$ & $8 / 15-12 / 16$ & $10 / 14-12 / 16$ & $8 / 15-12 / 16$ \\
\hline Total number of months in period & 24 & 17 & 27 & 17 \\
\hline Maintenance analysis base fleet kilometers & $1,136,291$ & 806,319 & $1,642,728$ & $1,056,343$ \\
\hline Average monthly kilometers per vehicle & 3,862 & 3,953 & 7,606 & 7,767 \\
\hline Availability (\%) & 90 & 90 & 93 & 93 \\
\hline Fleet fuel usage in kWh/CNG liter equiv. & $1,951,862.0$ & $1,087,276.0$ & $894,663.1$ & $618,415.2$ \\
\hline Roadcalls & 149 & 107 & 35 & 27 \\
\hline Total KMBRC & 7,626 & 7,536 & 46,935 & 39,124 \\
\hline Propulsion-related roadcalls & 55 & 40 & 18 & 14 \\
\hline Propulsion-related KMBRC & 20,660 & 20,158 & 91,263 & 75,453 \\
\hline Rep. fleet fuel consumption (L/100 km) & 13.50 & 13.54 & 53.53 & 54.17 \\
\hline $\begin{array}{l}\text { CNG fleet fuel consumption at similar } \\
\text { average driving speed as BEB fleet (L/100 } \\
\mathrm{km} \text { ) }\end{array}$ & & & 100.73 & 100.73 \\
\hline Energy cost per kWh & $\$ 0.18$ & $\$ 0.18$ & & \\
\hline CNG cost/liter & & & $\$ 0.25$ & $\$ 0.25$ \\
\hline $\begin{array}{l}\text { Energy/fuel cost per kilometer (based on } \\
\text { purchased energy) }\end{array}$ & $\$ 0.27$ & $\$ 0.26$ & $\$ 0.15$ & $\$ 0.15$ \\
\hline $\begin{array}{l}\text { CNG fuel cost per kilometer at similar } \\
\text { average driving speed as BEB fleet }\end{array}$ & & & $\$ 0.28$ & $\$ 0.28$ \\
\hline Total scheduled repair cost per kilometer & $\$ 0.04$ & $\$ 0.04$ & $\$ 0.08$ & $\$ 0.07$ \\
\hline Total unscheduled repair cost per kilometer & $\$ 0.08$ & $\$ 0.09$ & $\$ 0.05$ & $\$ 0.06$ \\
\hline Total maintenance cost per kilometer & $\$ 0.12$ & $\$ 0.13$ & $\$ 0.13$ & $\$ 0.13$ \\
\hline $\begin{array}{l}\text { Total operating cost per kilometer (as } \\
\text { operated) }\end{array}$ & $\$ 0.39$ & $\$ 0.39$ & $\$ 0.28$ & $\$ 0.29$ \\
\hline $\begin{array}{l}\text { Total operating cost per mile at similar } \\
\text { average driving speed, excluding tire } \\
\text { costs }\end{array}$ & $\$ 0.35$ & $\$ 0.34$ & $\$ 0.40$ & $\$ 0.41$ \\
\hline
\end{tabular}




\section{Maintenance Costs}

\begin{tabular}{|l|r|r|r|r|}
\hline & \multicolumn{1}{|c|}{$\begin{array}{c}\text { BEB } \\
\text { All Data }\end{array}$} & $\begin{array}{c}\text { BEB } \\
\text { Report } \\
\text { Period }\end{array}$ & \multicolumn{1}{c|}{$\begin{array}{c}\text { CNG } \\
\text { All Data }\end{array}$} & $\begin{array}{c}\text { CNG } \\
\text { Report } \\
\text { Period }\end{array}$ \\
\hline Fleet mileage & $1,136,291$ & 806,319 & $1,642,728$ & $1,056,343$ \\
\hline Total parts cost $(\$)$ & $54,932.79$ & $45,588.07$ & $108,879.49$ & $76,117.76$ \\
\hline Total labor hours & $1,647.94$ & $1,165.54$ & $1,997.20$ & $1,317.75$ \\
\hline Average labor cost $(@ \$ 50.00$ per hour) $(\$)$ & $82,397.00$ & $58,277.00$ & $99,860.00$ & $65,887.50$ \\
\hline Total maintenance cost $(\$)$ & $137,329.79$ & $103,865.07$ & $208,739.49$ & $142,005.26$ \\
\hline Total maintenance cost per bus $(\$)$ & $11,444.15$ & $8,655.42$ & $17,394.96$ & $11,833.77$ \\
\hline Total maintenance cost per kilometer $(\$)$ & $\mathbf{0 . 1 2}$ & $\mathbf{0 . 1 3}$ & $\mathbf{0 . 1 3}$ & $\mathbf{0 . 1 3}$ \\
\hline $\begin{array}{l}\text { Total maintenance cost per kilometer, } \\
\text { excluding tire costs }(\$)\end{array}$ & $\mathbf{0 . 0 8}$ & $\mathbf{0 . 0 8}$ & $\mathbf{0 . 1 2}$ & $\mathbf{0 . 1 2}$ \\
\hline
\end{tabular}




\section{Appendix D: Charts for Entire In-Service Period (All Data)}

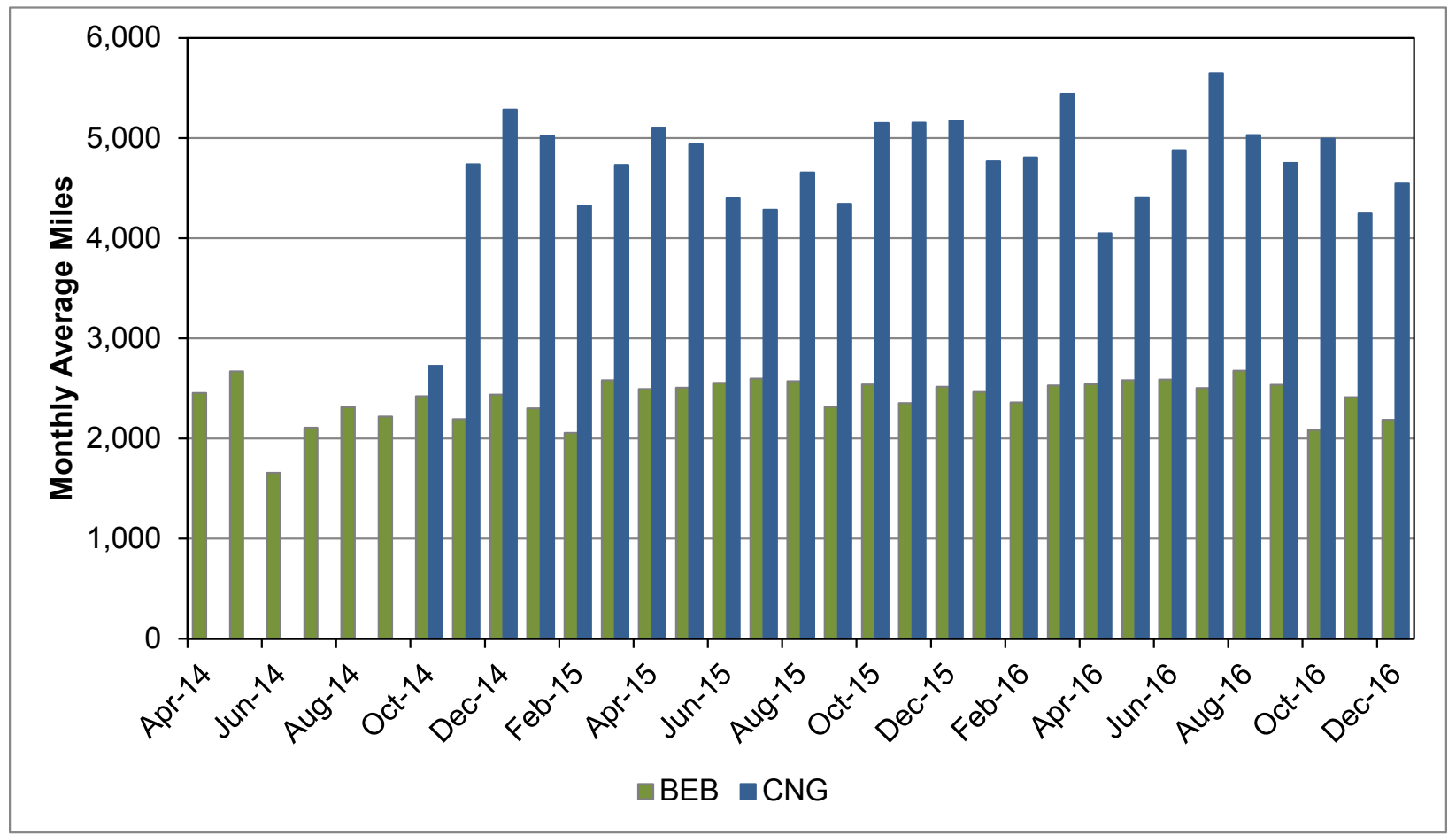

Figure D-1. Monthly average miles for the BEBs and CNG buses

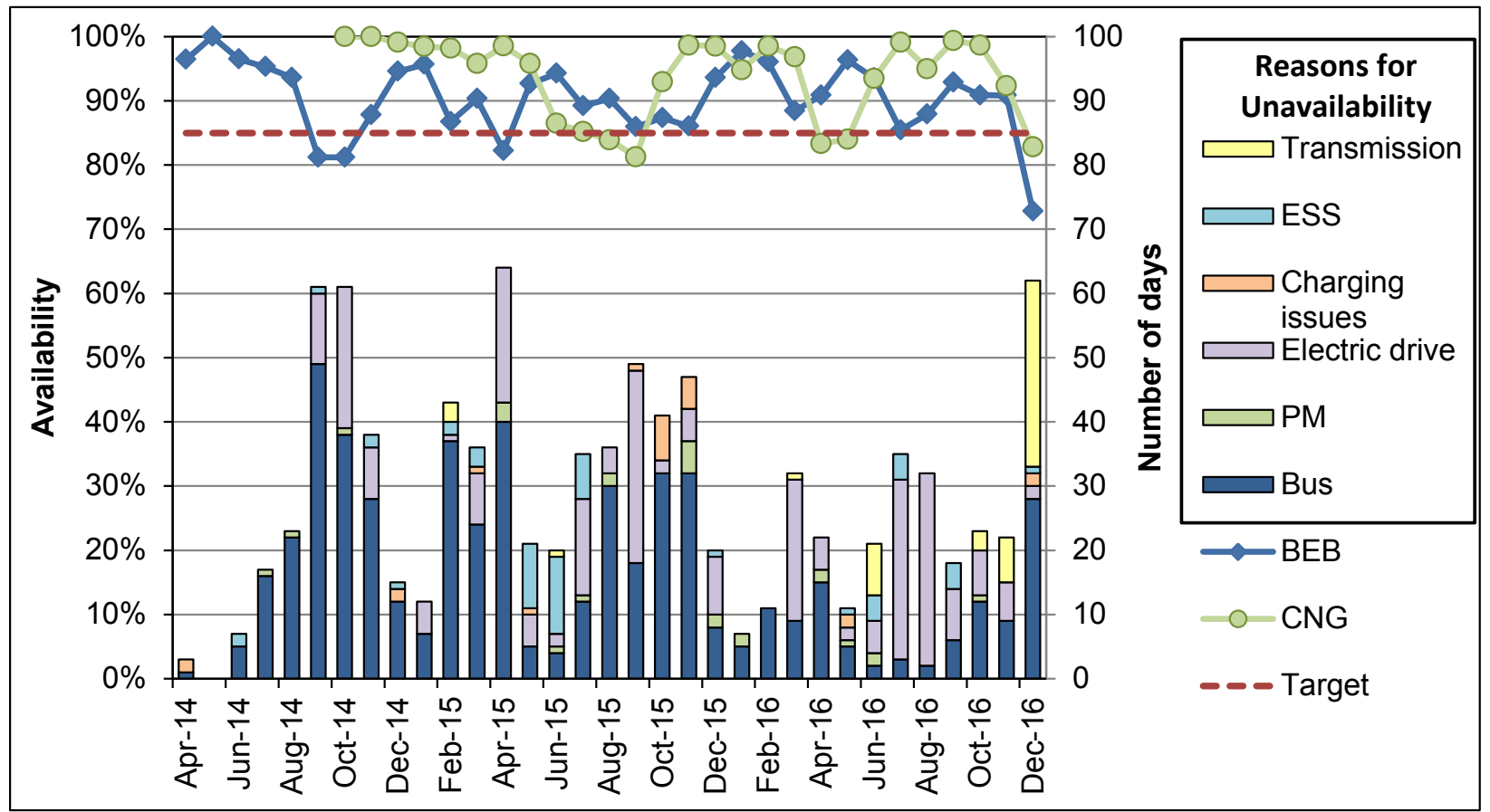

Figure D-2. Monthly availability for the BEBs and CNG buses 


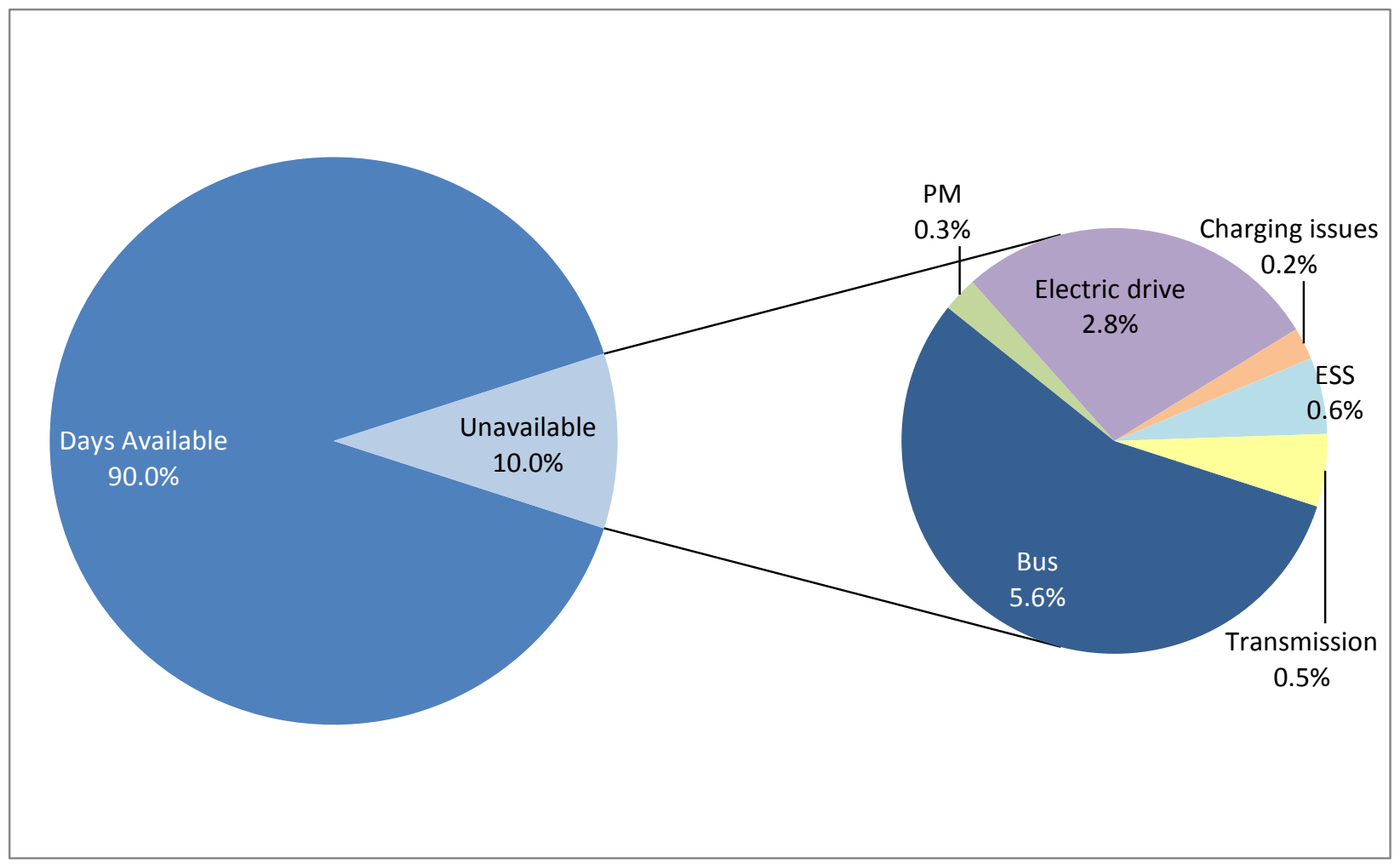

Figure D-3. Overall availability and reasons for unavailability for the BEBs

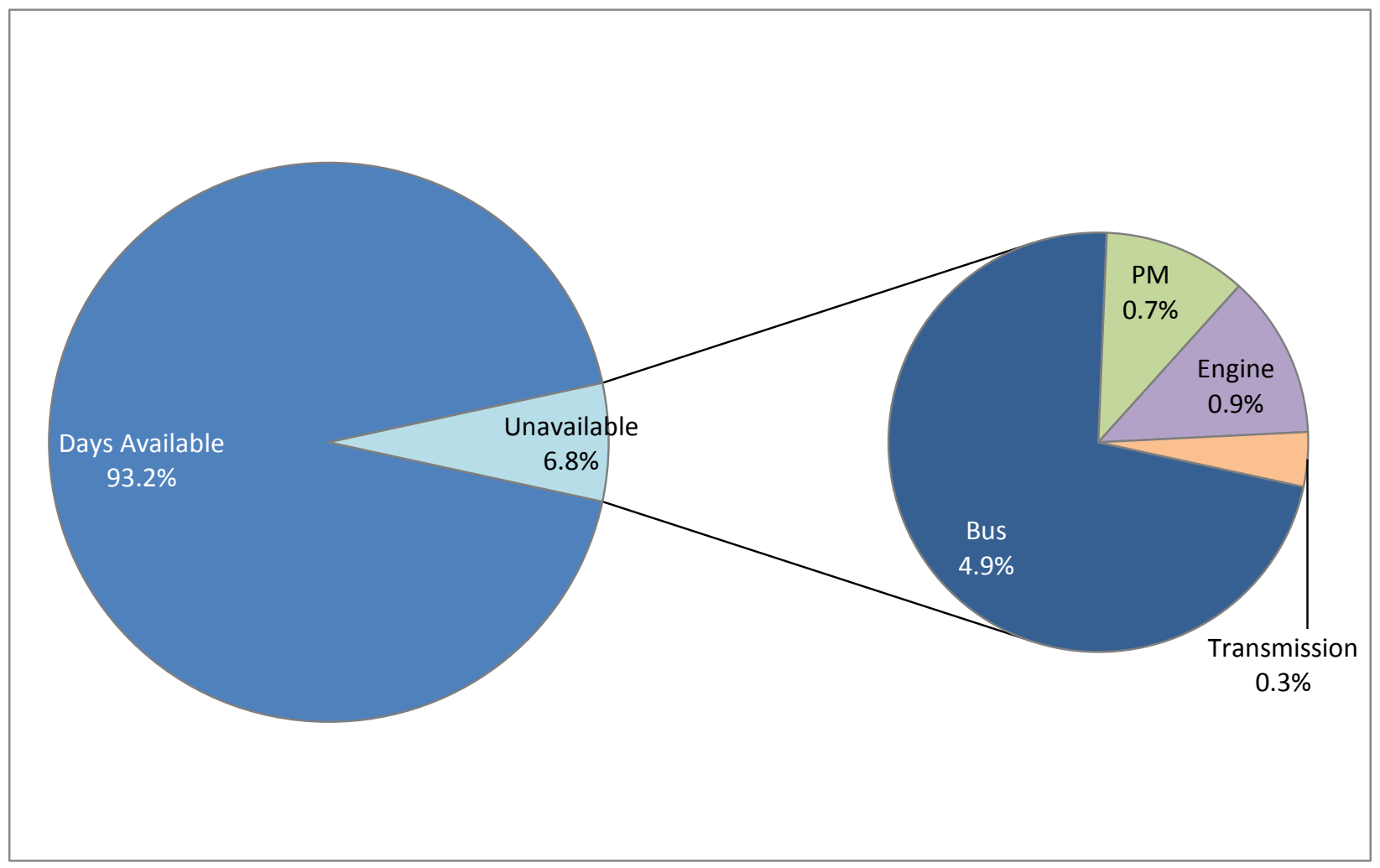

Figure D-4. Overall availability and reasons for unavailability for the CNG buses 


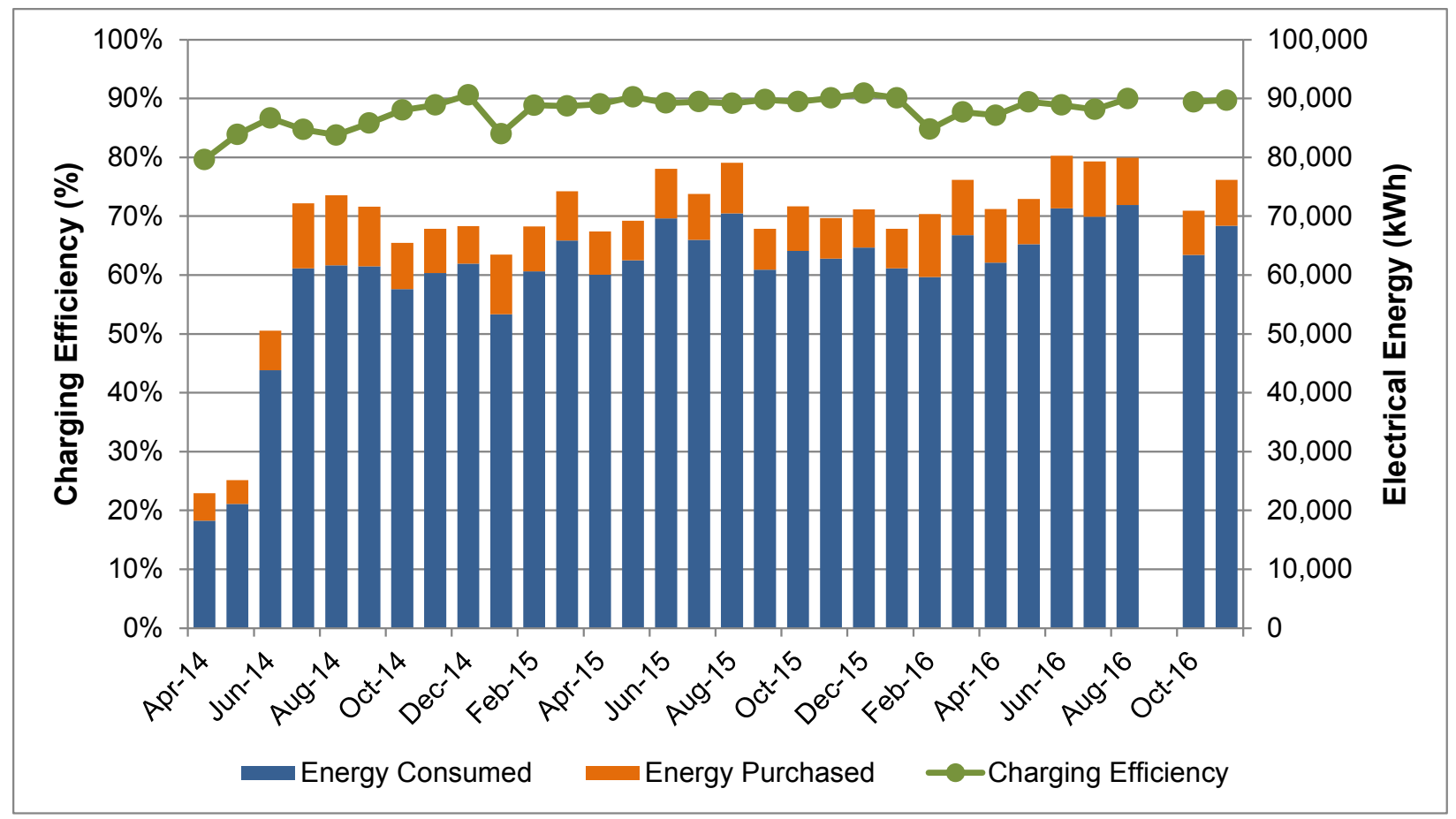

Figure D-5. Monthly energy consumption and overall charging efficiency for the BEBs

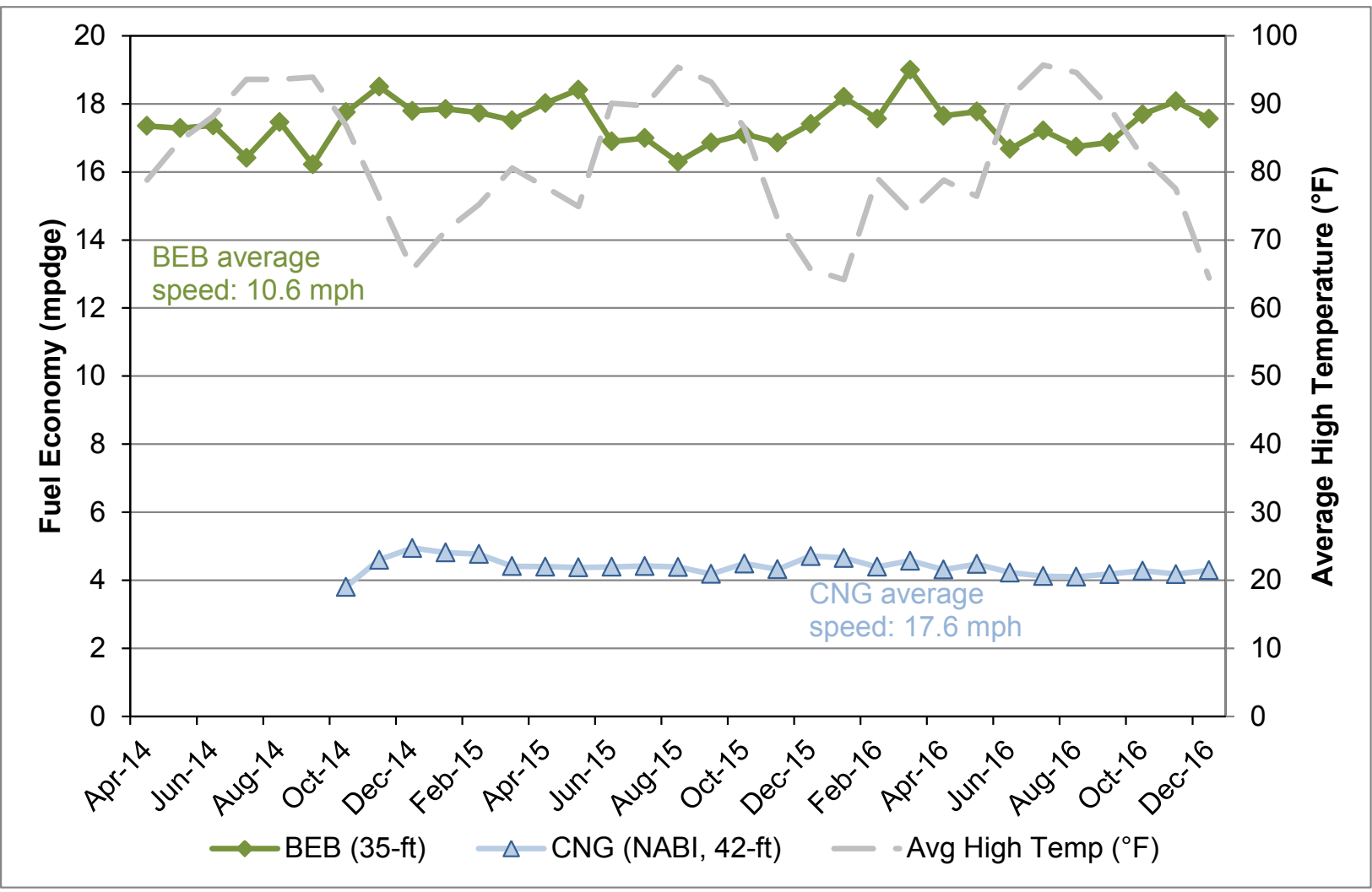

Figure D-6. Monthly average fuel economy for the BEBs and CNG buses 


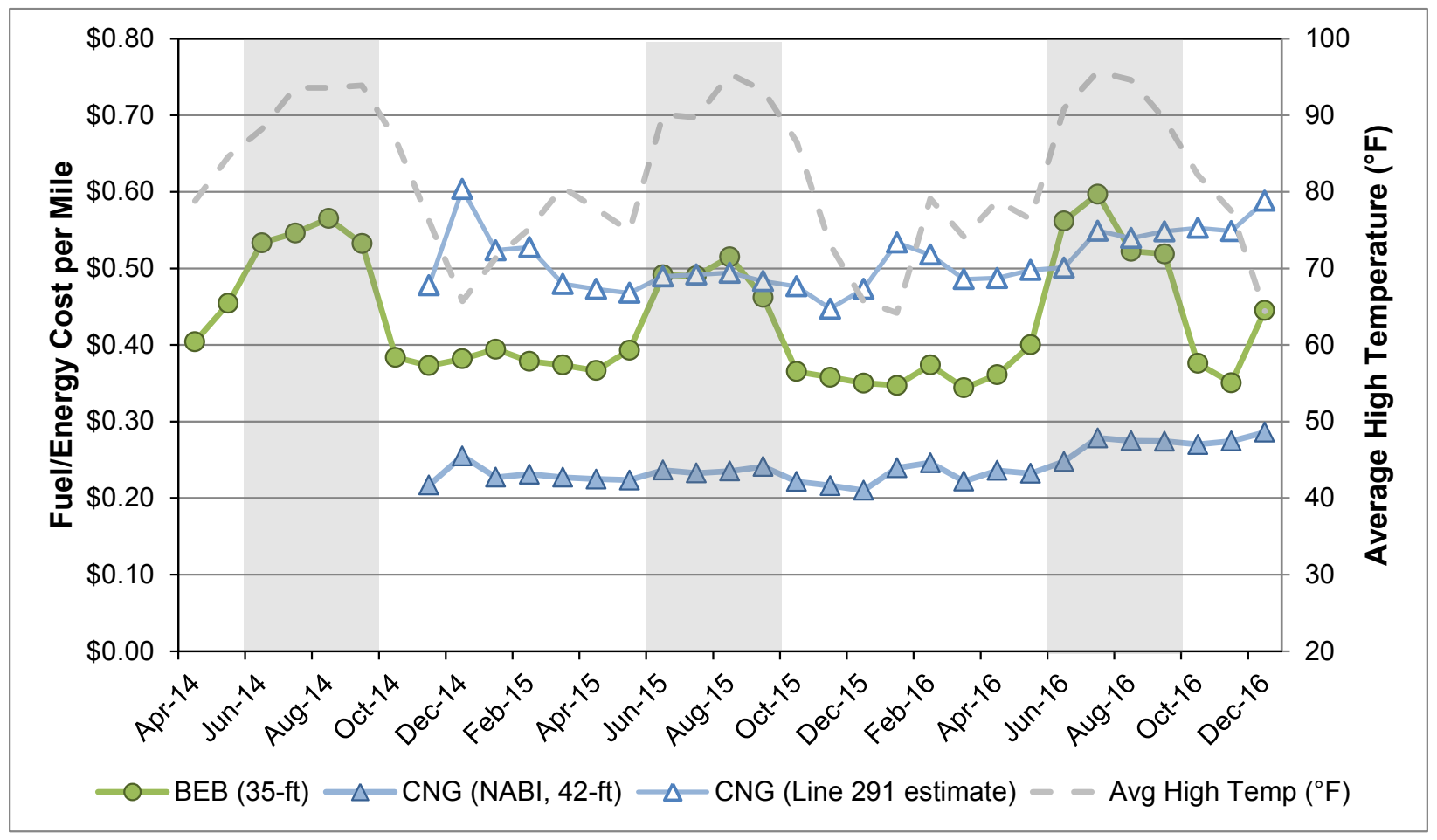

Figure D-7. Monthly average energy cost per mile for the BEBs and CNG buses

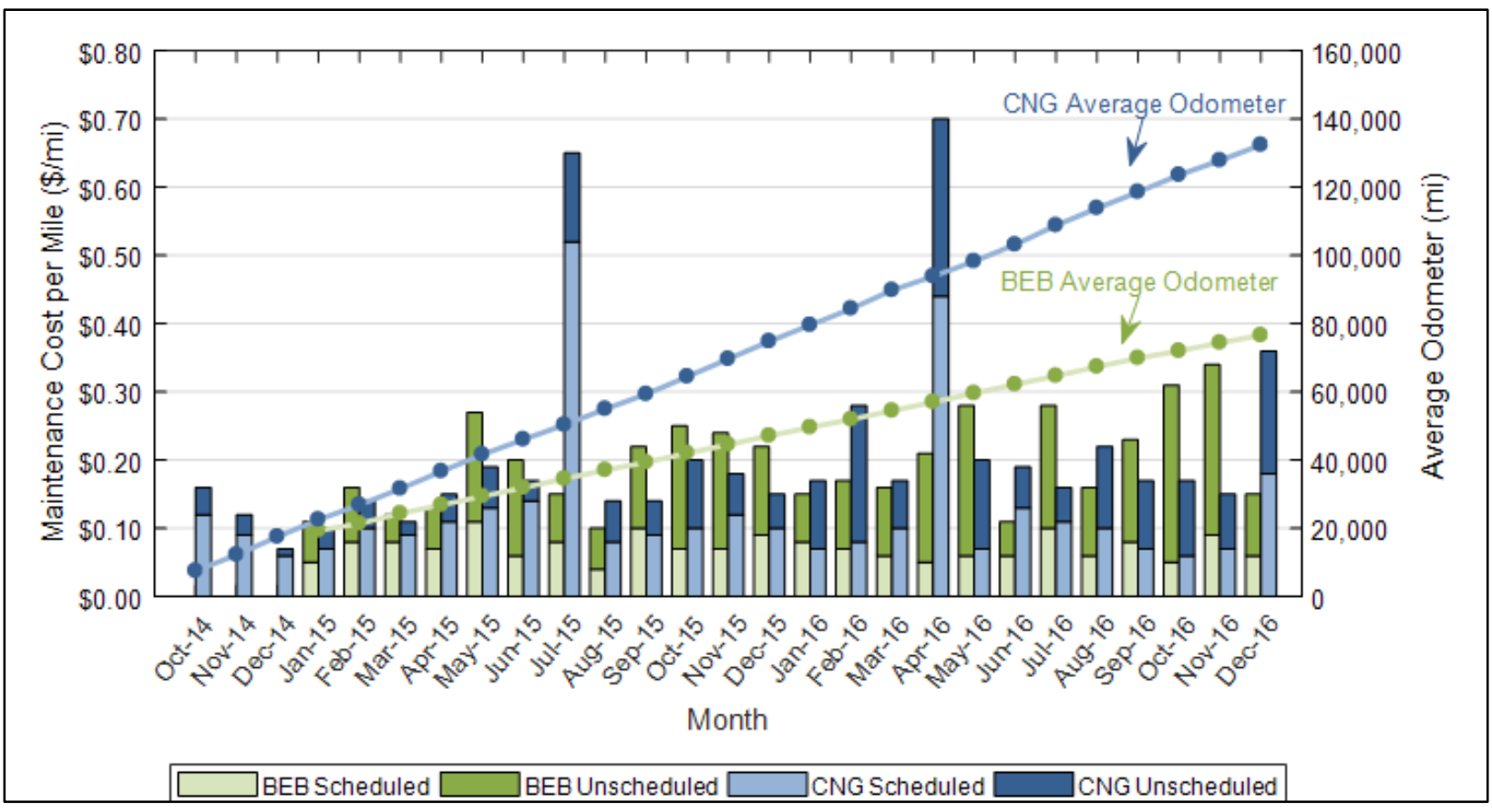

Figure D-8. Monthly scheduled and unscheduled maintenance costs per mile for the BEBs and CNG buses 


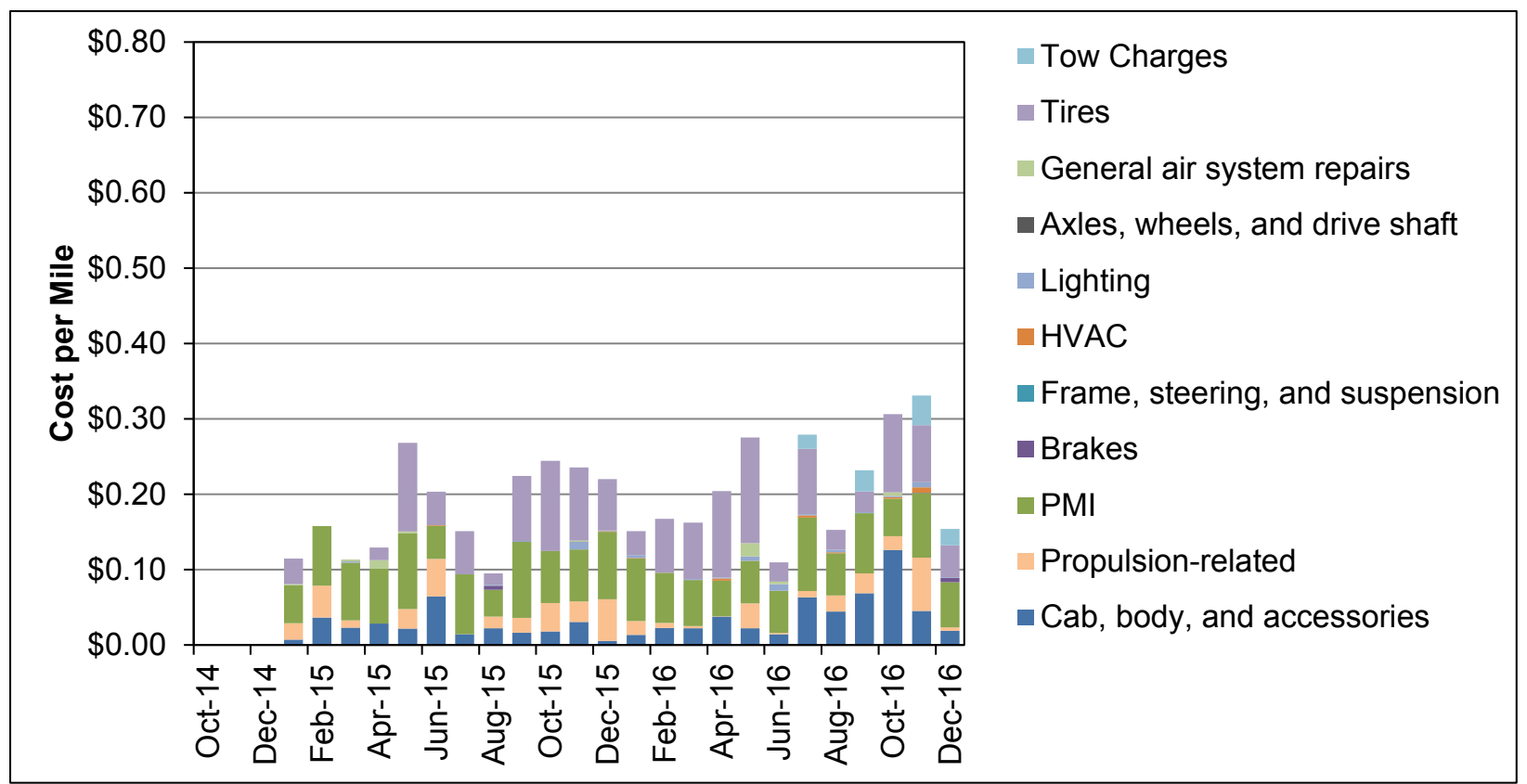

Figure D-9. Monthly maintenance cost per mile by vehicle system for the BEBs

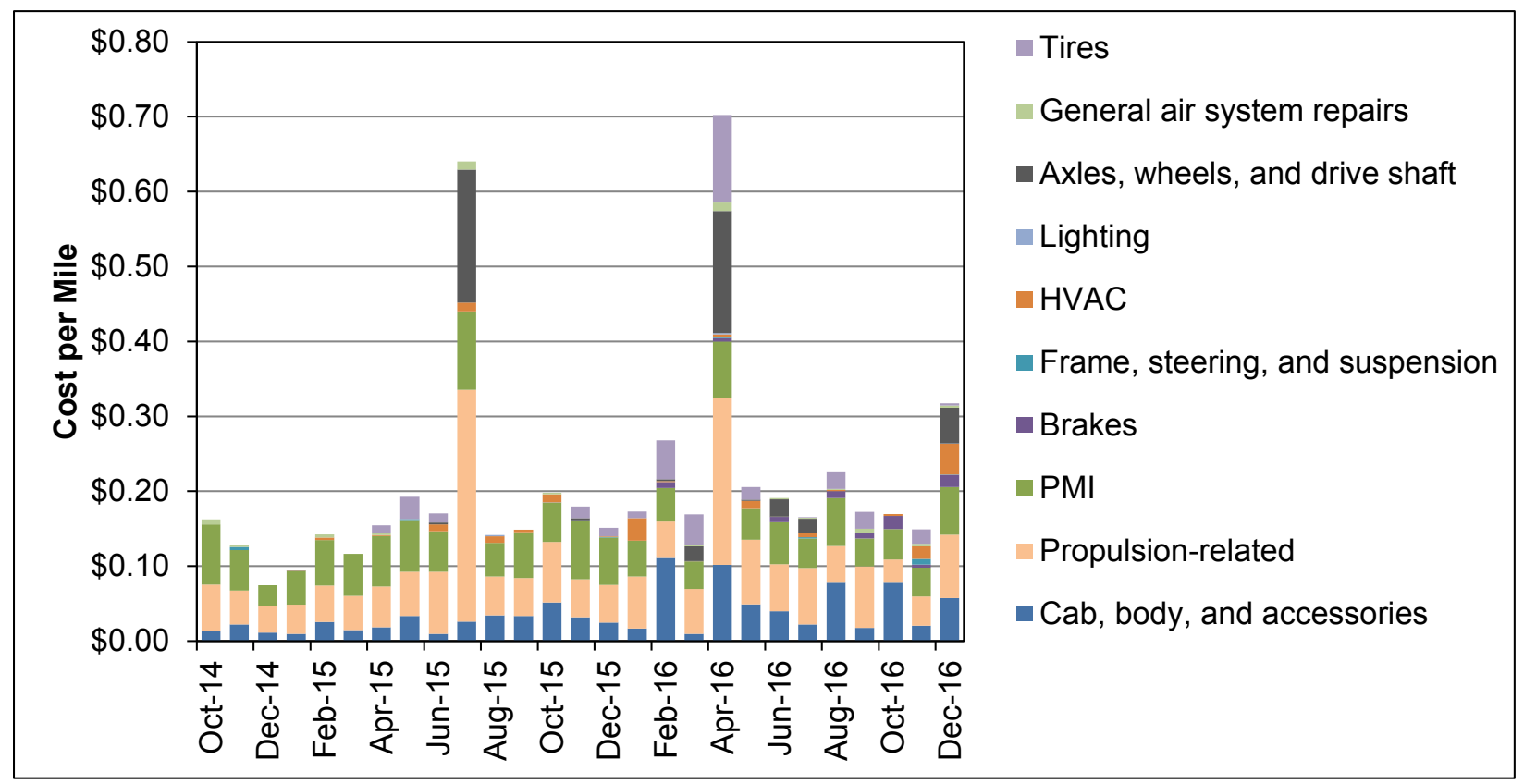

Figure D-10. Monthly maintenance cost per mile by vehicle system for the CNG buses 